\title{
BROOKHBVEN
}

NATIONAL LABORATORY

BNL-112744-2016

\section{Low-Cost 3D Position-Sensitive CZT High-Granularity Detectors}

\author{
Aleksey Bolotnikov \\ Presented at the NA-22 Independent Review \\ Brookhaven National Laboratory, Upton, NY \\ October 5-6, 2016 \\ October 6, 2016

\begin{abstract}
Nonproliferation and National Security Department Radiation Detector and Nonproliferation R\&D

Brookhaven National Laboratory
\end{abstract}

\section{U.S. Department of Energy \\ USDOE National Nuclear Security Administration (NNSA), Office of Nonproliferation and Verification Research and Development (NA-22)}

\footnotetext{
Notice: This manuscript has been authored by employees of Brookhaven Science Associates, LLC under Contract No. DE-SC0012704 with the U.S. Department of Energy. The publisher by accepting the manuscript for publication acknowledges that the United States Government retains a non-exclusive, paid-up, irrevocable, worldwide license to publish or reproduce the published form of this manuscript, or allow others to do so, for United States Government purposes.
} 


\section{DISCLAIMER}

This report was prepared as an account of work sponsored by an agency of the United States Government. Neither the United States Government nor any agency thereof, nor any of their employees, nor any of their contractors, subcontractors, or their employees, makes any warranty, express or implied, or assumes any legal liability or responsibility for the accuracy, completeness, or any third party's use or the results of such use of any information, apparatus, product, or process disclosed, or represents that its use would not infringe privately owned rights. Reference herein to any specific commercial product, process, or service by trade name, trademark, manufacturer, or otherwise, does not necessarily constitute or imply its endorsement, recommendation, or favoring by the United States Government or any agency thereof or its contractors or subcontractors. The views and opinions of authors expressed herein do not necessarily state or reflect those of the United States Government or any agency thereof. 


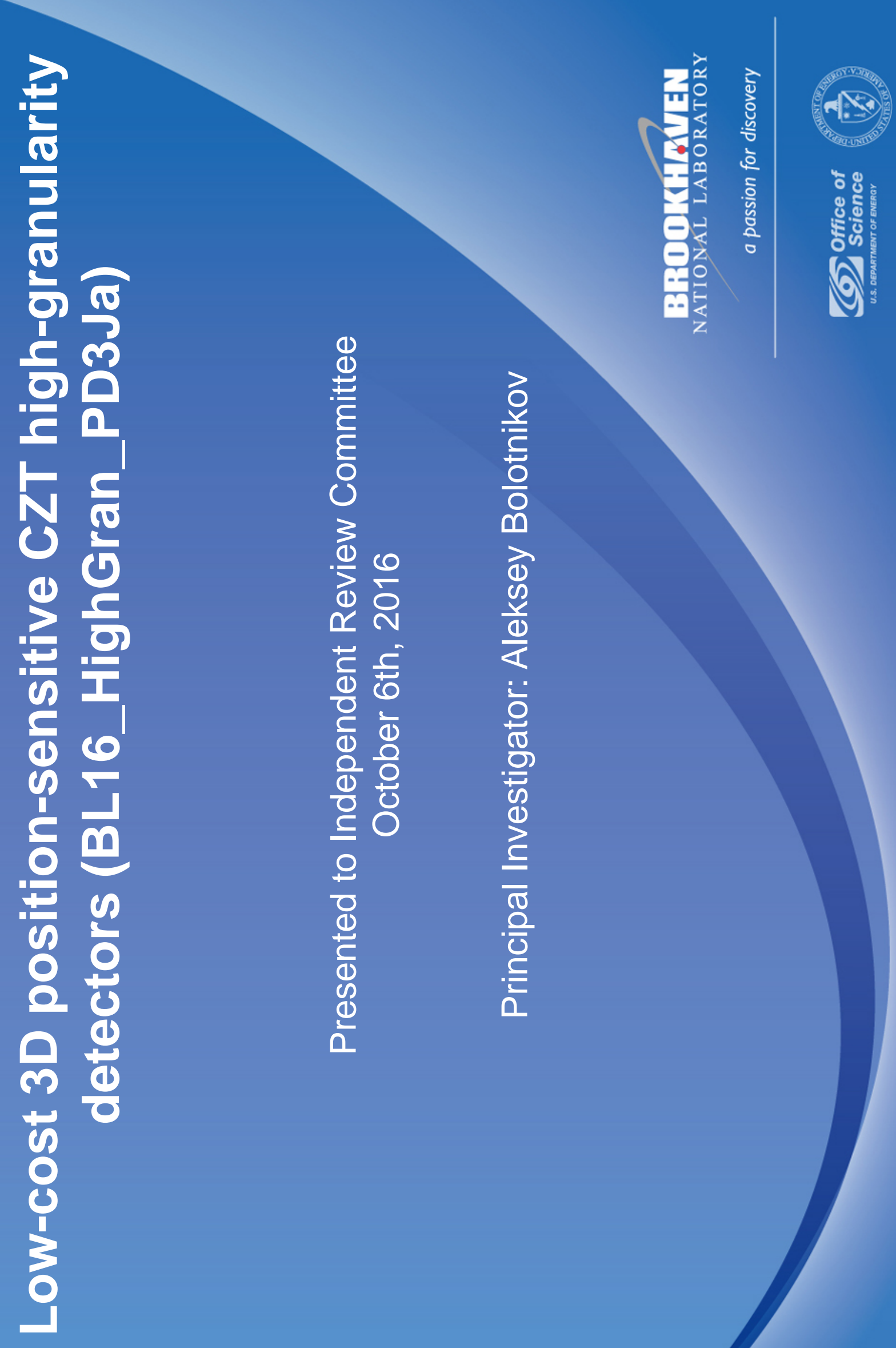




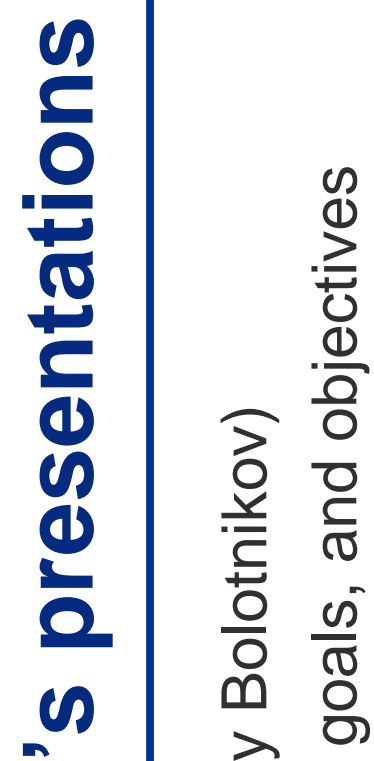

बें

过 온

उ 잉

(ब)

$>20$

(ब) पू

ब $\frac{9}{5}$

임

늠

흠

$\stackrel{?}{=}$

$\stackrel{\frac{E}{\Phi}}{\rightleftarrows}$

$\stackrel{\square}{\pi}$

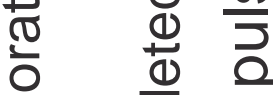

은

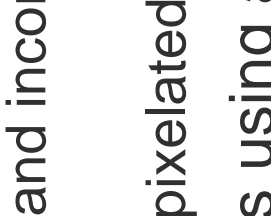

i) 을 के 은

d

兽㝴

$\subseteq \stackrel{\square}{ \pm}$

ฮั

บ के 高

응 훙 으

ฮ $\bar{\alpha}: \frac{\bar{y}}{\overline{0}}$

을 즘 응

잉

क 응

匹

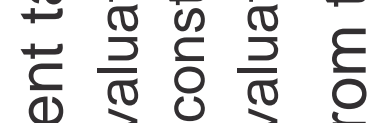

임, , ,

营

जे त

व

$\stackrel{\sigma}{\sigma} \leftarrow \frac{\omega}{v}$

드 1 U

$\sum_{0}^{1} \stackrel{0}{0}$

\& 0 u

< $\frac{1}{0} \frac{0}{0}$

$\frac{1}{0} \pm$

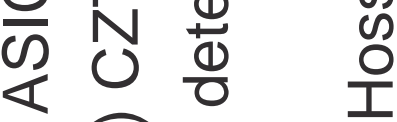

ค Е

m $\Omega$

I 0

으으 오

도 르

인

(1)

(1)

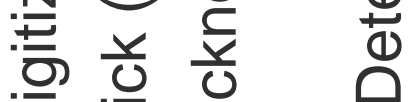

高

을 끌

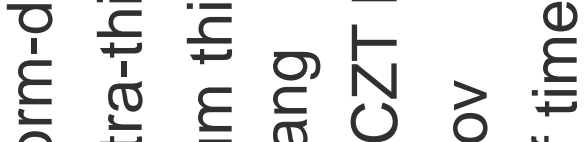

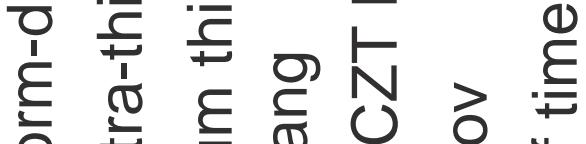

늘 Е

خ

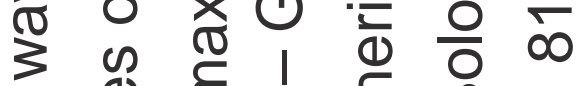

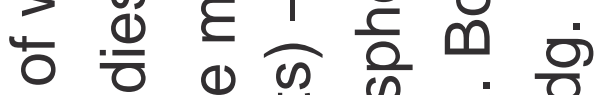

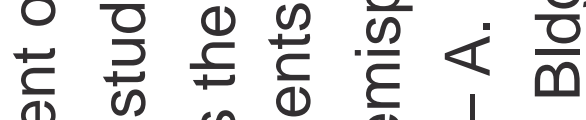

(1) थ ฮ ब ।

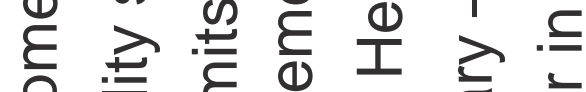

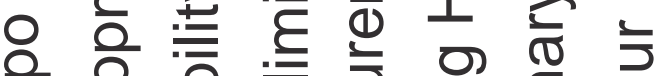

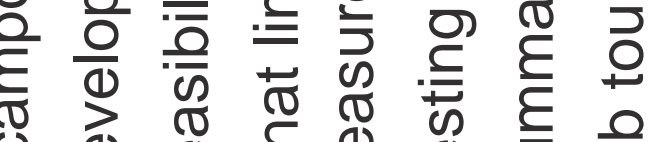

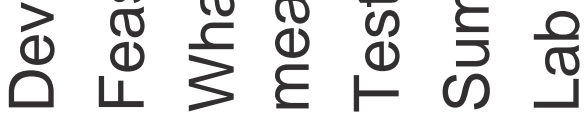




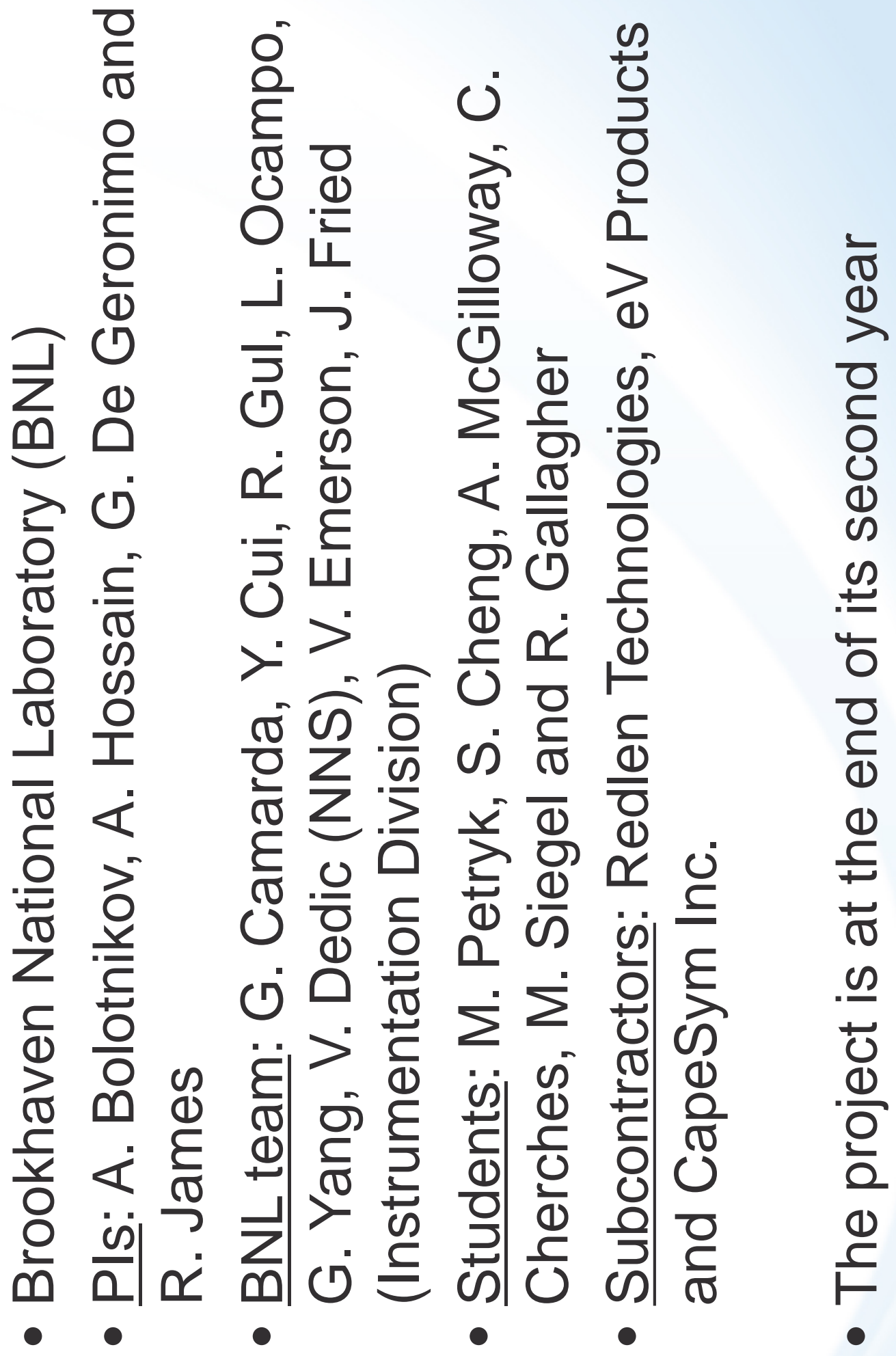




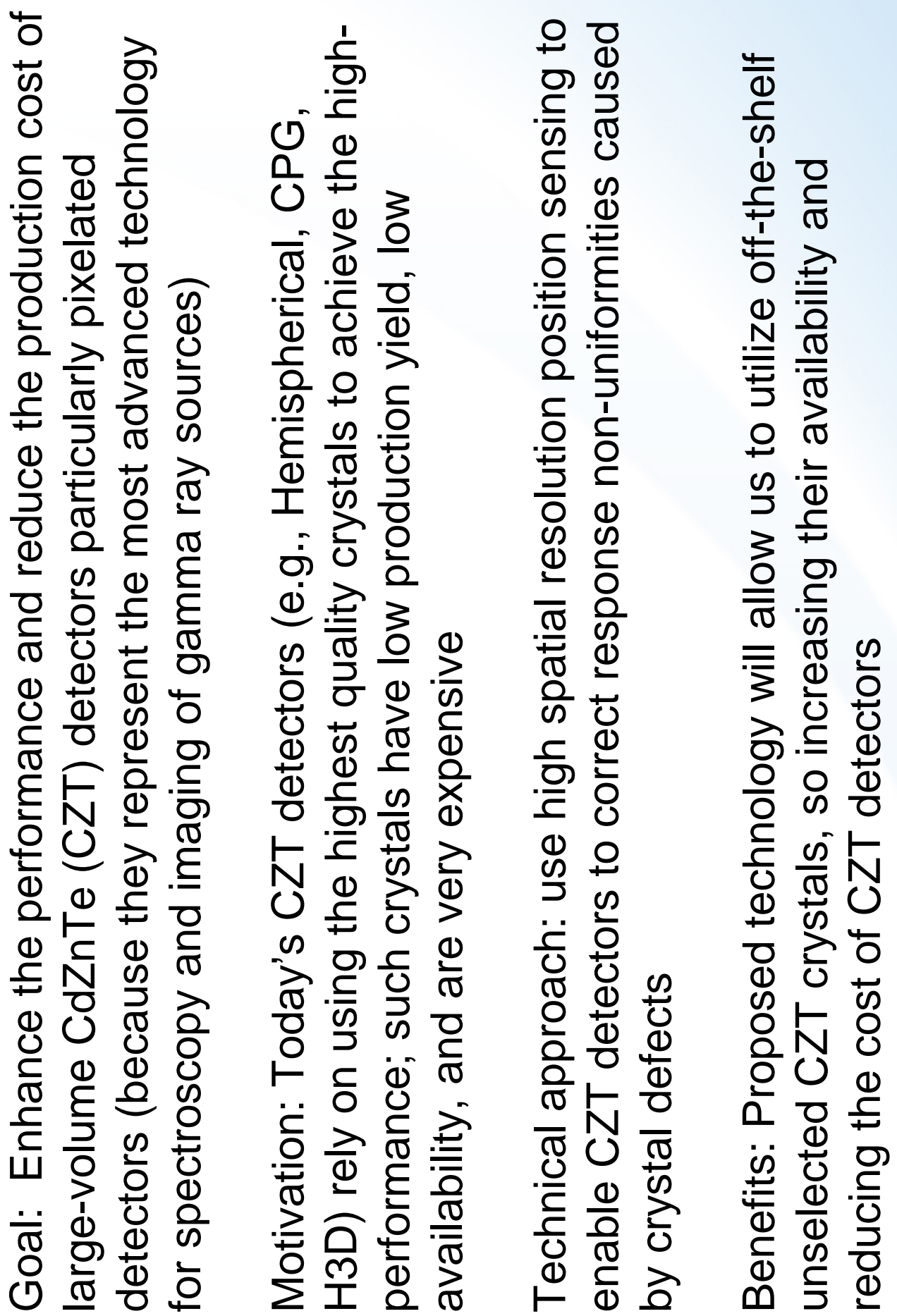


0

(1)

ज

()

d)

농

ชర

(1)

은

$\rightleftarrows$

(1)

है

0

능

트

$\frac{7}{2}$

पั0

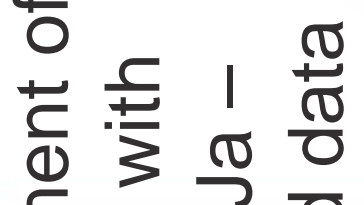

응 늠

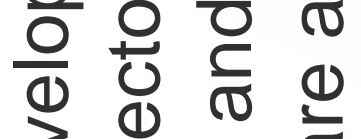

व)

응 엉 깅

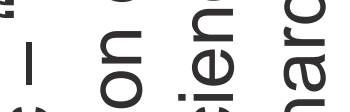

을

N $\frac{0}{0} \frac{1}{0}$

๘

(1)

光 於

(1) 잉

Ф

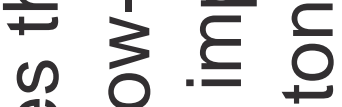

(⿻) 으응

ஸ)

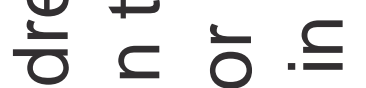

宁

눙뜽 잉

प ब ब

ब

흥어에

.

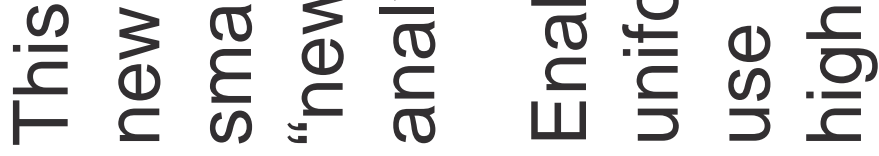


(1)

过 $\frac{\sqrt{0}}{3}$

응

व

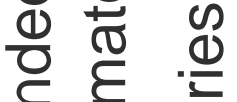

ब,

视

$>$ 을 $\frac{0}{0}$

임

立

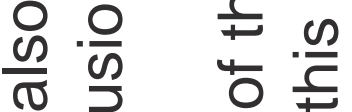

舟.

$\frac{\Phi}{2} \stackrel{0}{\vdash}$

(e)

包

क ज

(1) \&

드 흥 동

웅

(1)

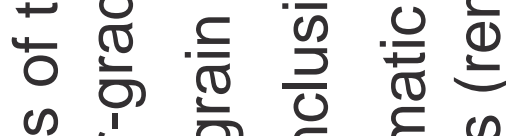

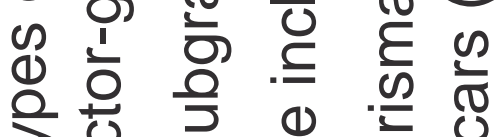

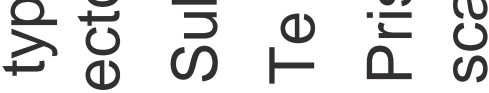

ब)

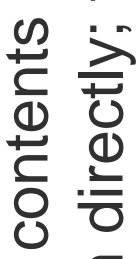

$\frac{\pi}{0} \frac{\varepsilon}{0}$

化

के

$\stackrel{0}{0}$

일

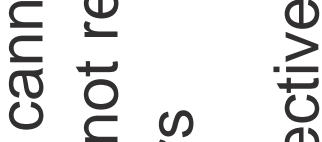

is

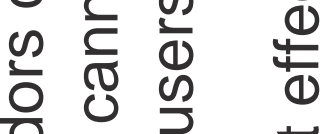

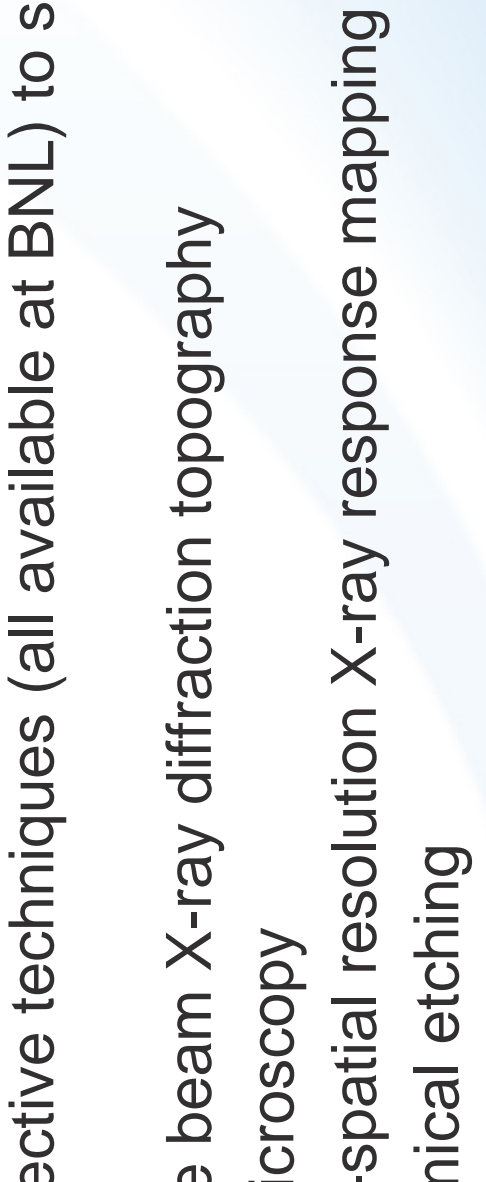
$\stackrel{\rightleftarrows}{\models}$ 
iิ $\frac{n}{\infty}$ 它

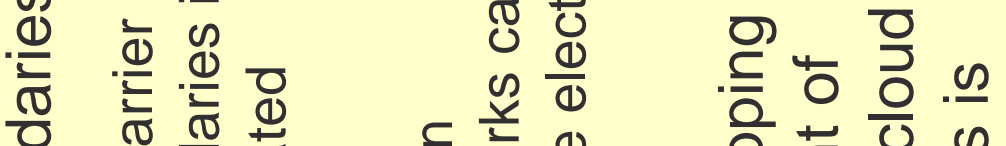

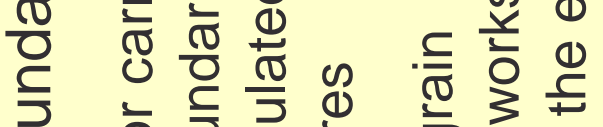

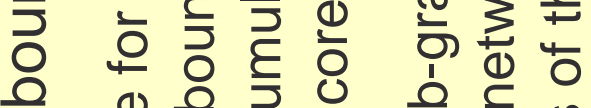

.

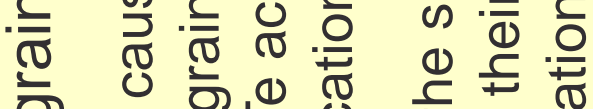

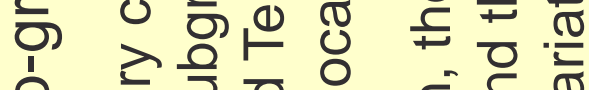

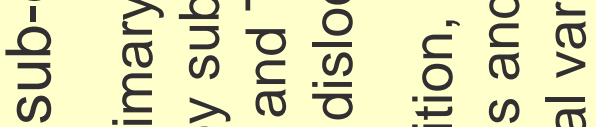

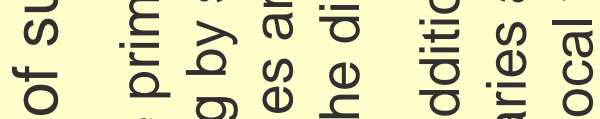

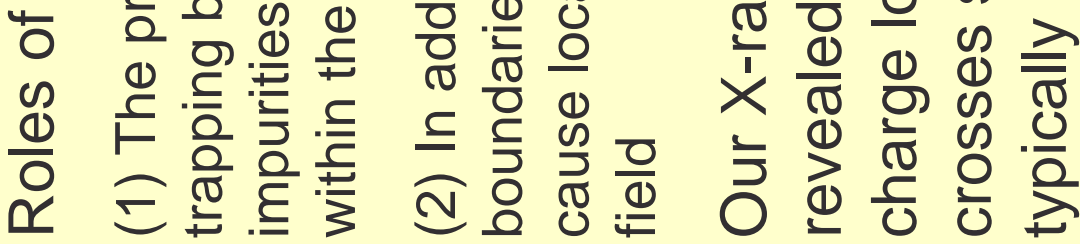

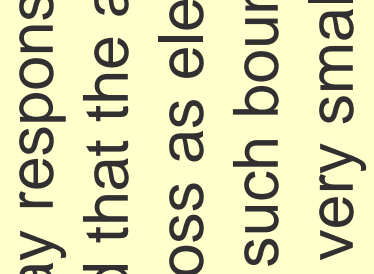

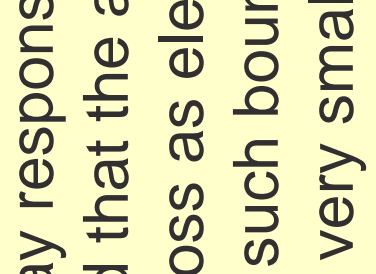

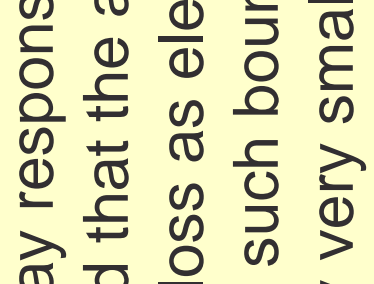

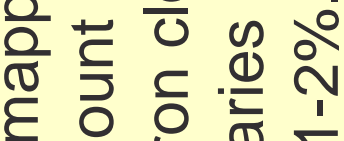

$\varepsilon$ 음허

凹

돈

(9)

d

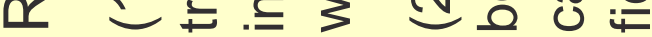

ก)

후르

을 $\frac{\text { के }}{2}$

喜

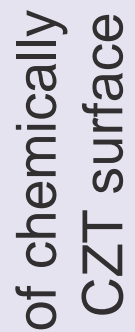

\%

원

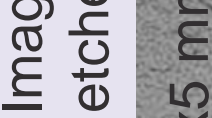

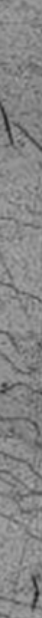

ס

흥

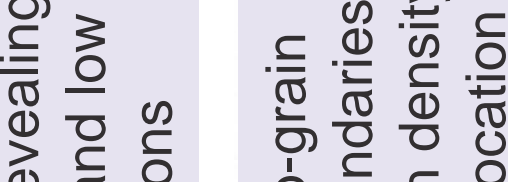

ఏ 흐음

응등 융

4

(1)

है

ஸे 을 을 음

$\frac{N}{E}$
$\frac{2}{x}$
$\frac{\operatorname{n}}{1}$

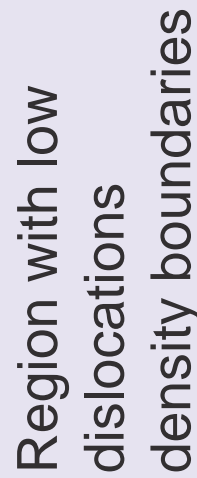




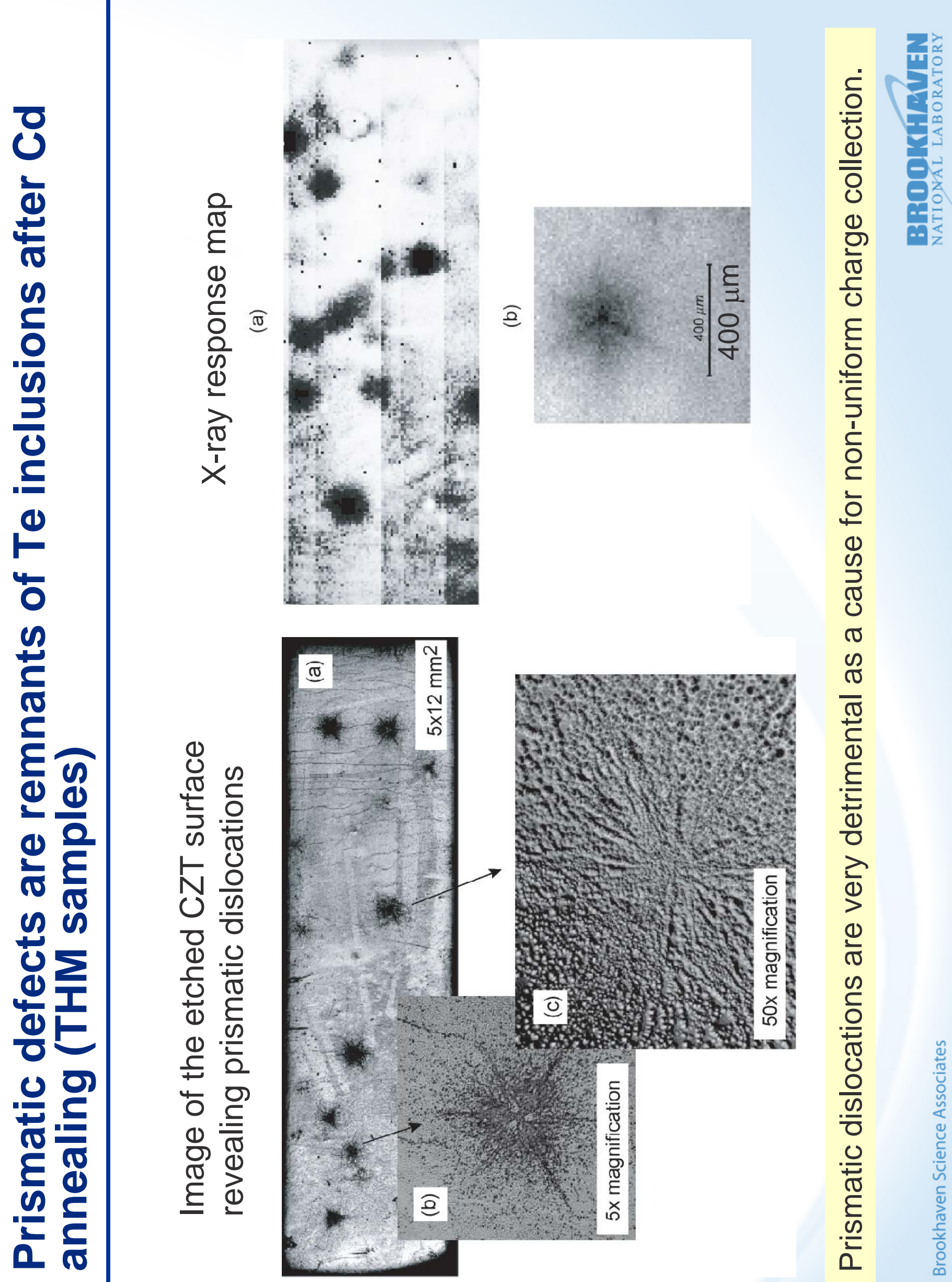




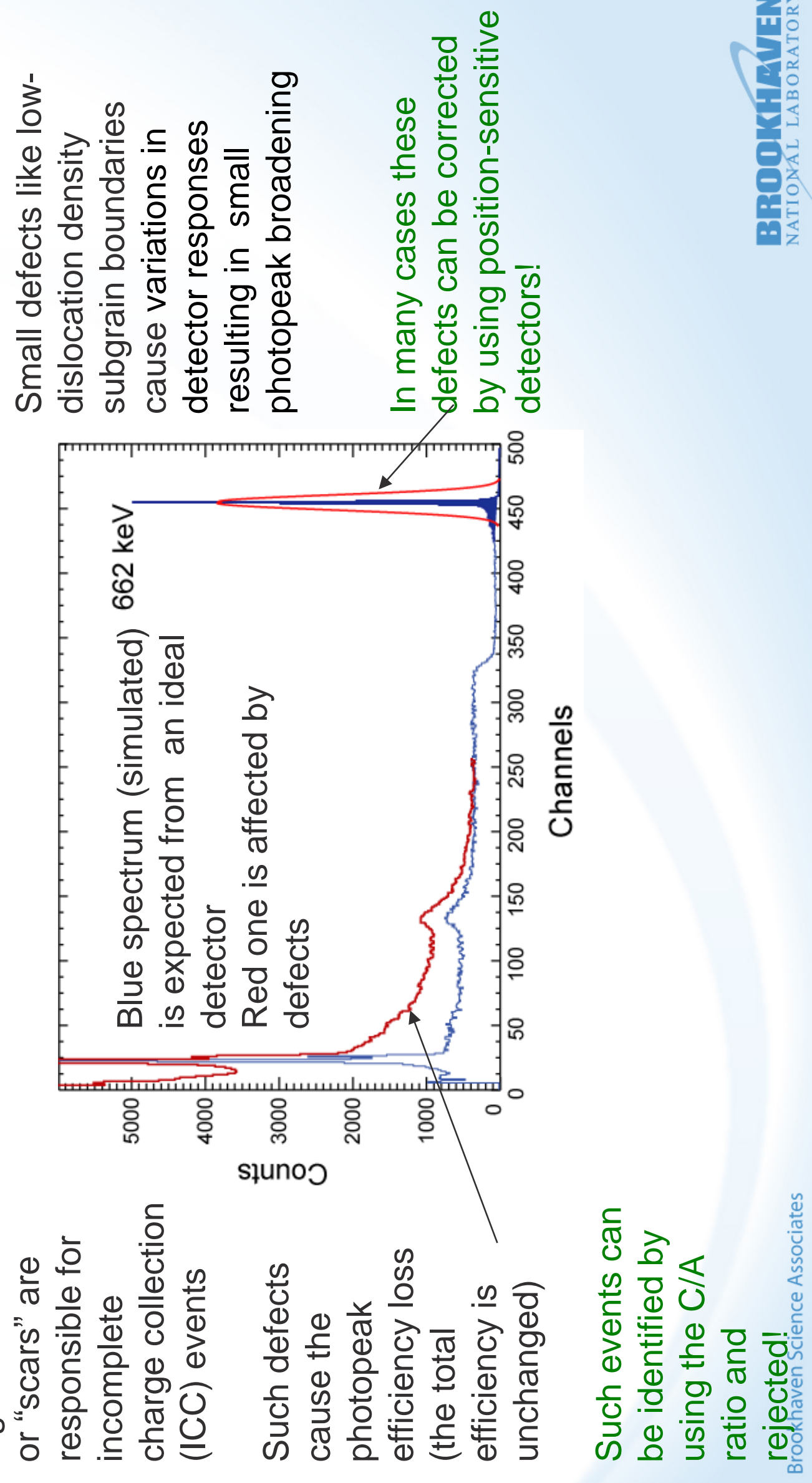




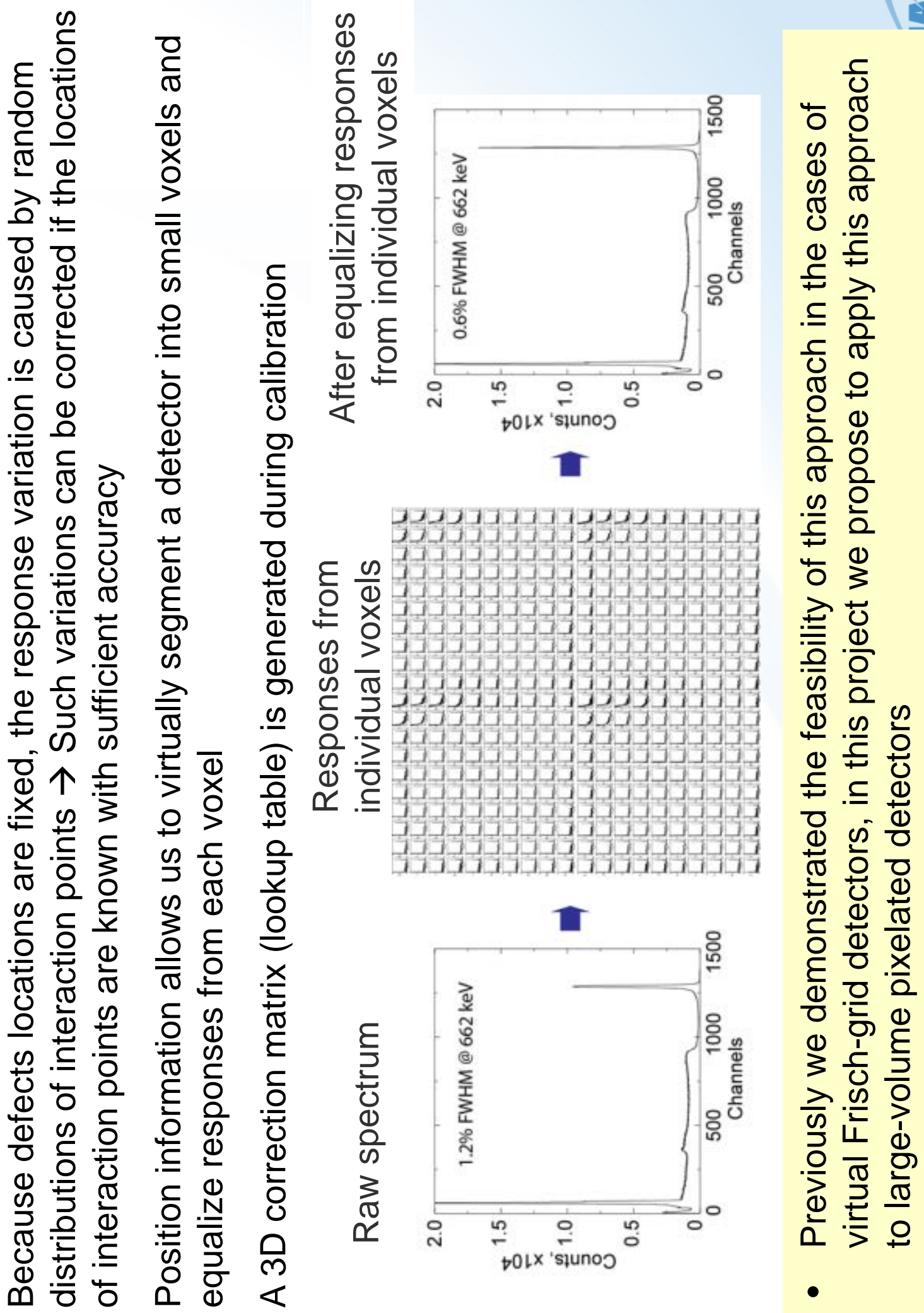




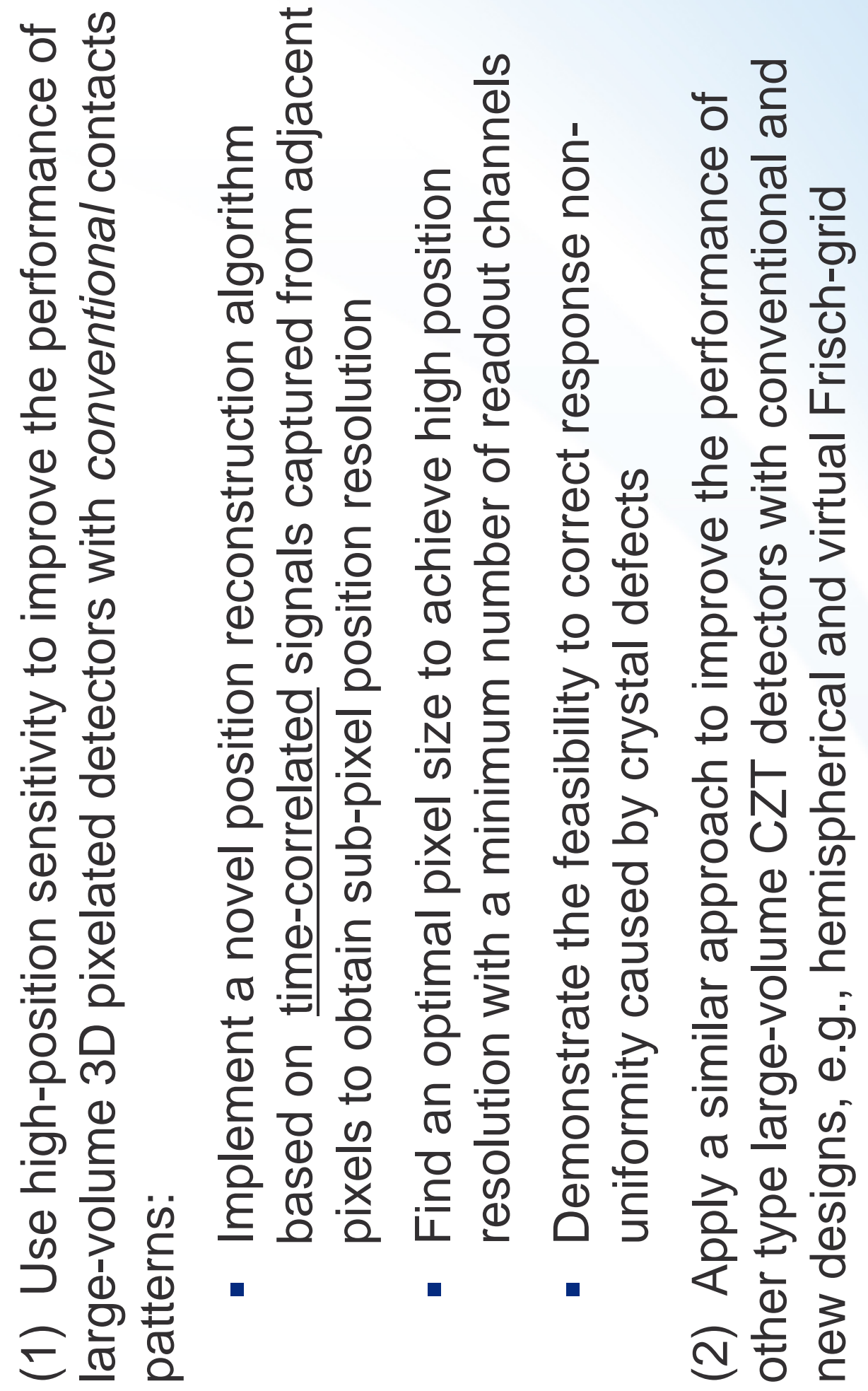




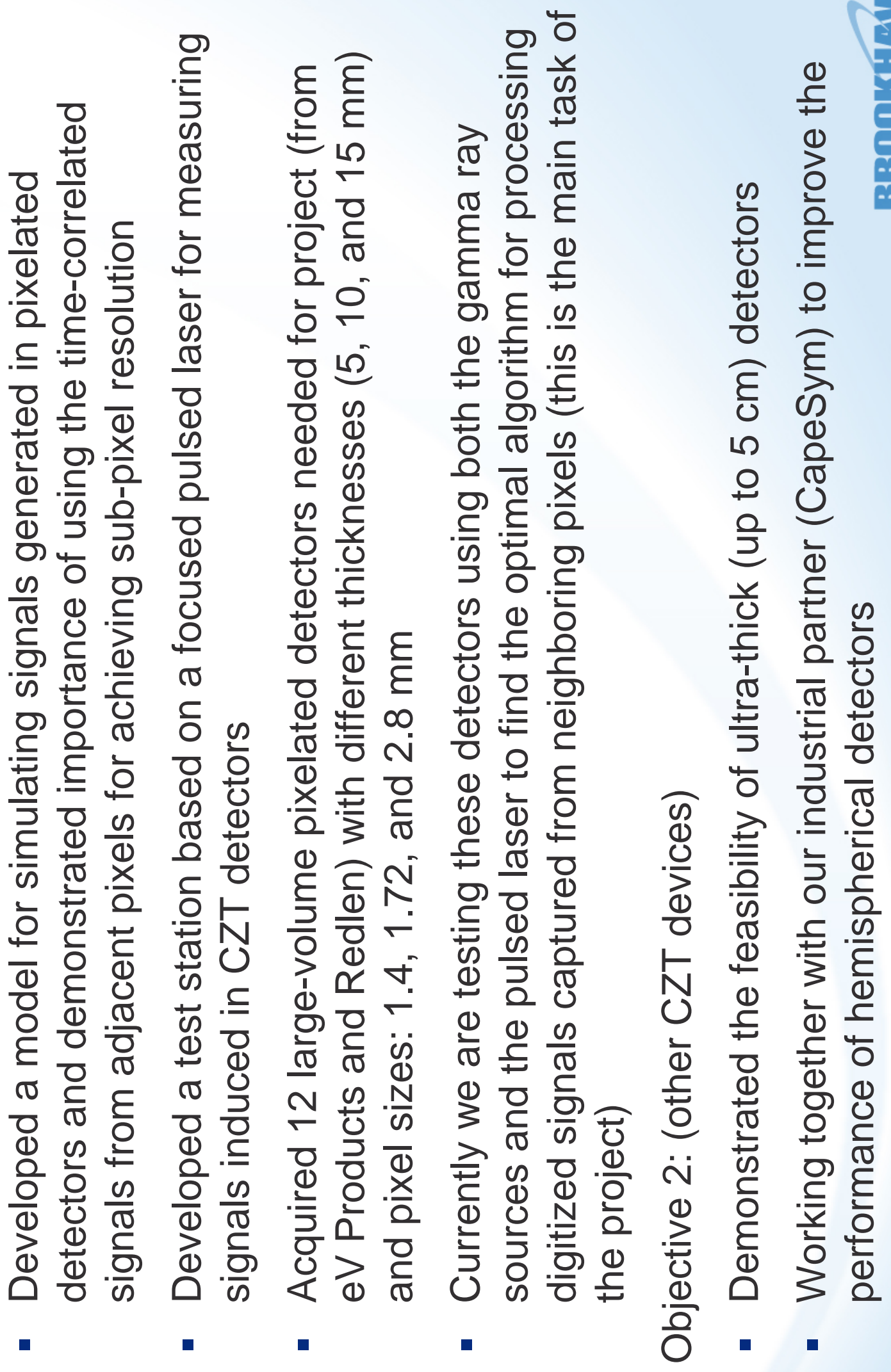


으

○

(U)

\% 0

(1)

x

'를

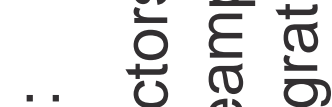

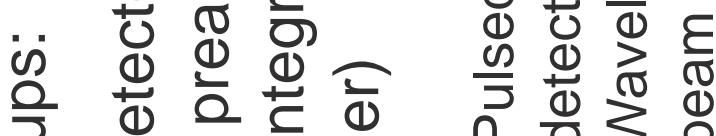

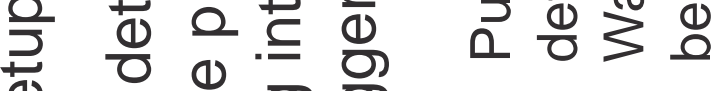

证

ज $0: \geqq$

त थ ज

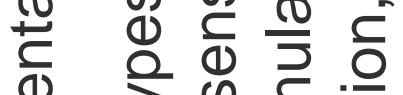

¿

$\fallingdotseq \pm d \overline{0}$

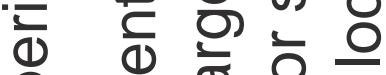

잉 흔

现过

응 은 을 정

क

을 용

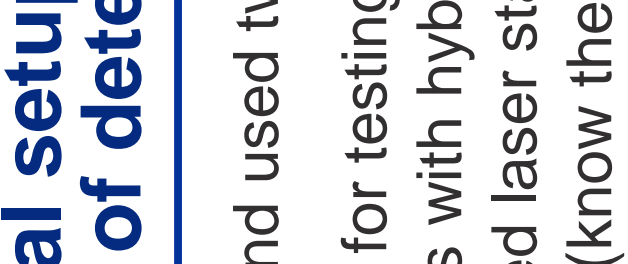

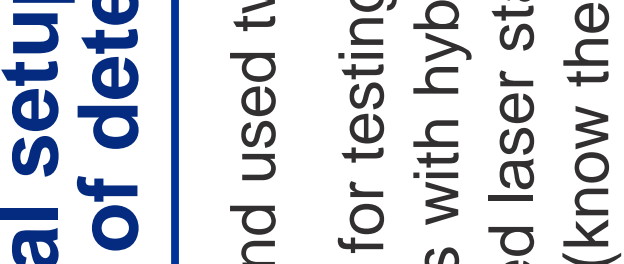

世

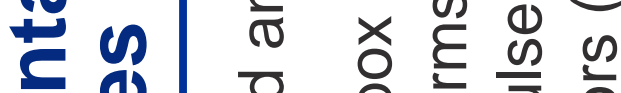

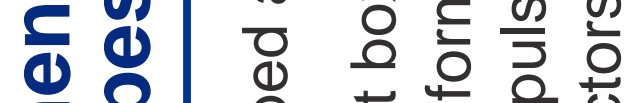

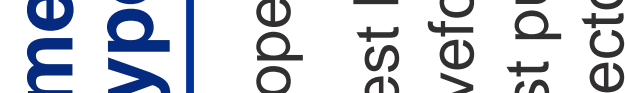

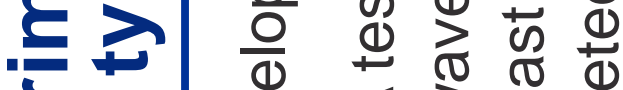

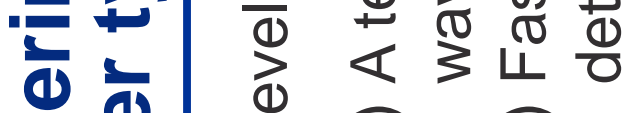

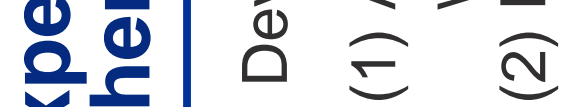

N

음

$\stackrel{9}{\leftrightarrows}$

ᄒํำ

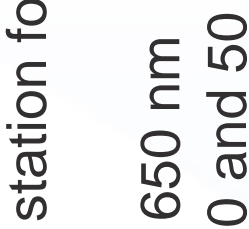

ळ $\ddot{\bar{E}}$

ฮิ ๗

워

(1)

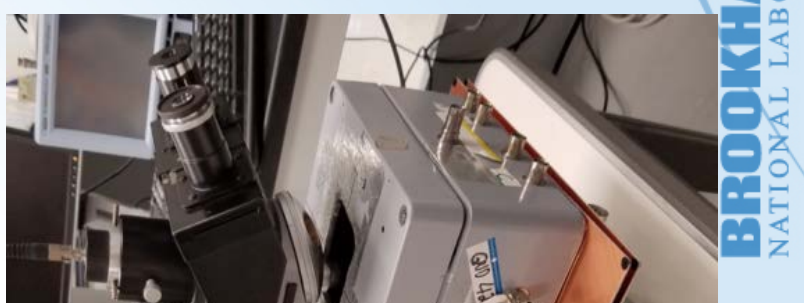

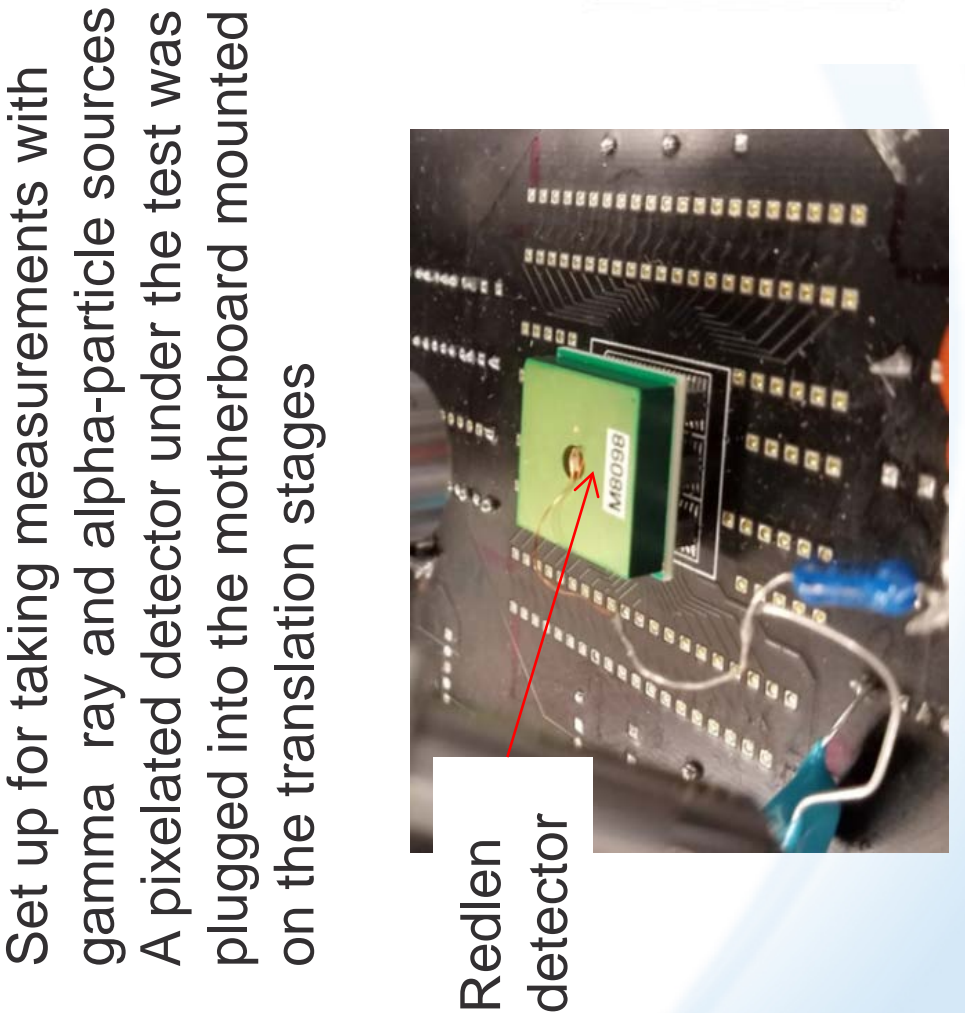


이됼

(1)

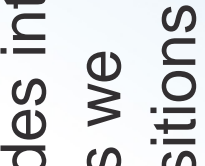

O) $\frac{v}{\sigma}$

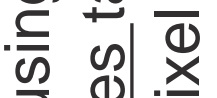

릉응

$5 \frac{1}{0} \cdot \frac{x}{0}$

을 을 을

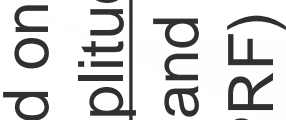

(1) ह

สে $\sqsupseteq \frac{1}{0}$

๙ $\frac{\bar{\sigma}}{\sigma} \frac{\Omega}{\sigma}$

ฮ 1 (1)

으름을

ชู

ช 0 正

$\frac{1}{\varepsilon} \stackrel{1}{\varepsilon} \frac{1}{\circ}$

ซே

( ) 워 है

(1) (1) (1)

๕

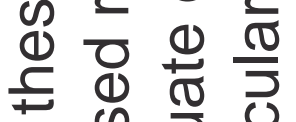

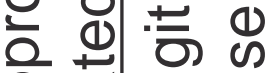

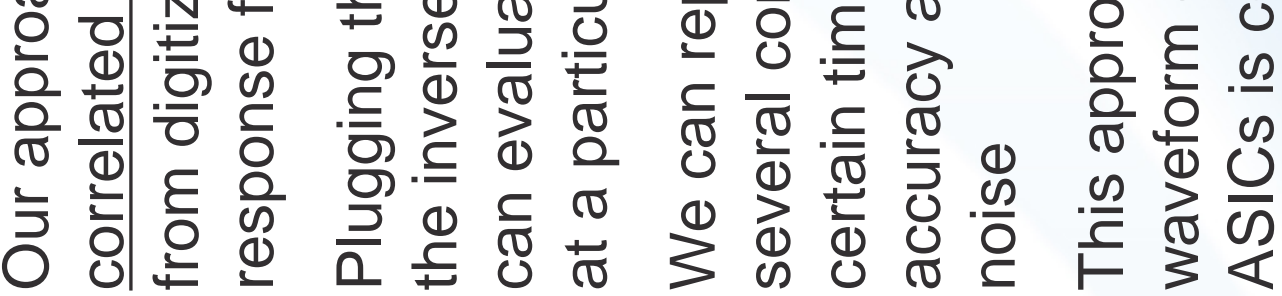

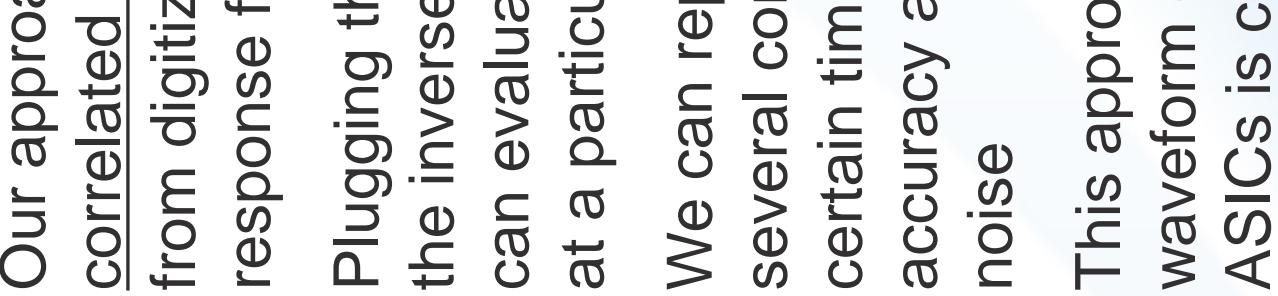

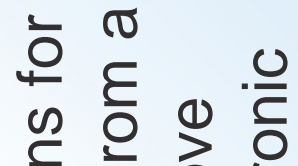

$\frac{c}{\frac{U}{5}}$
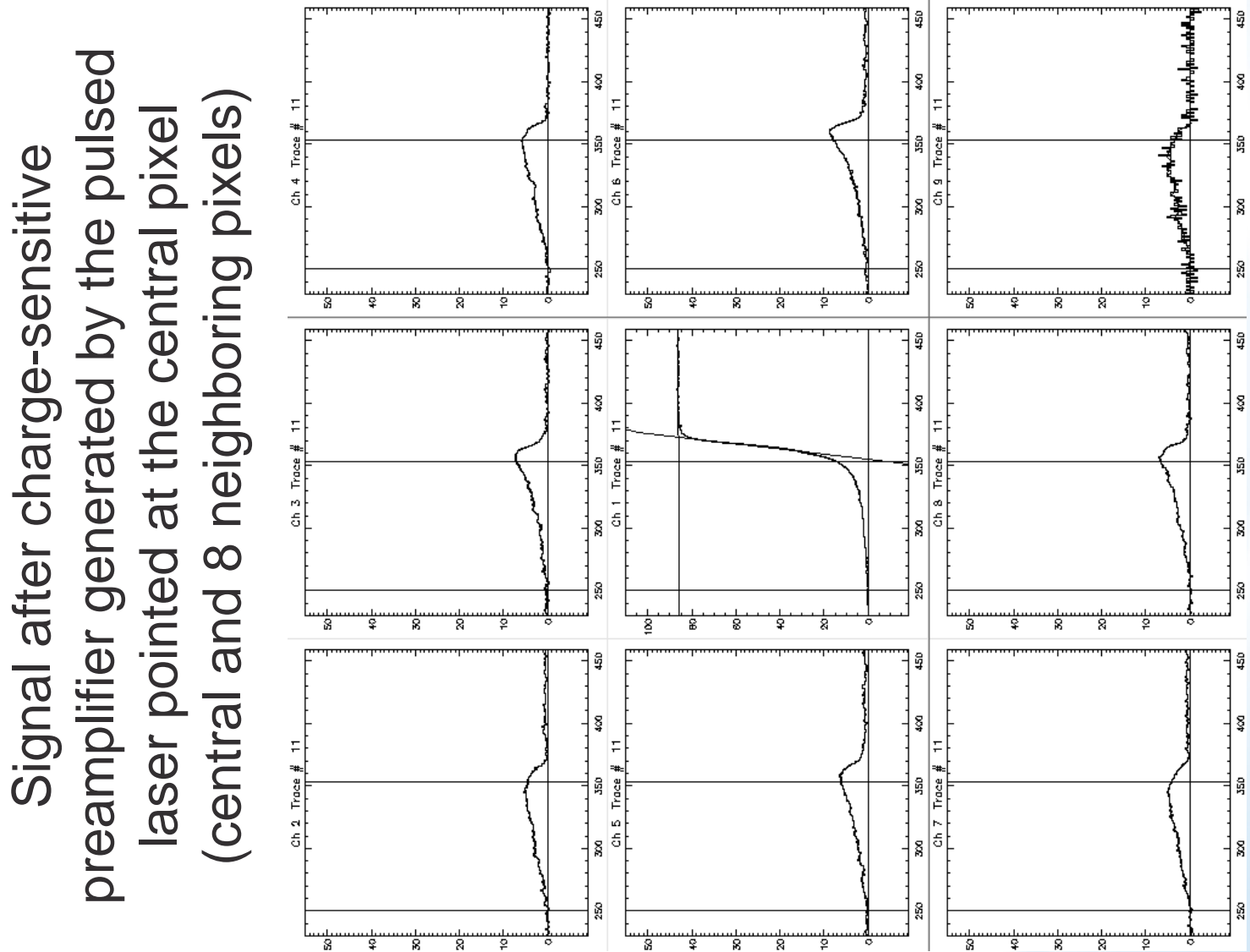


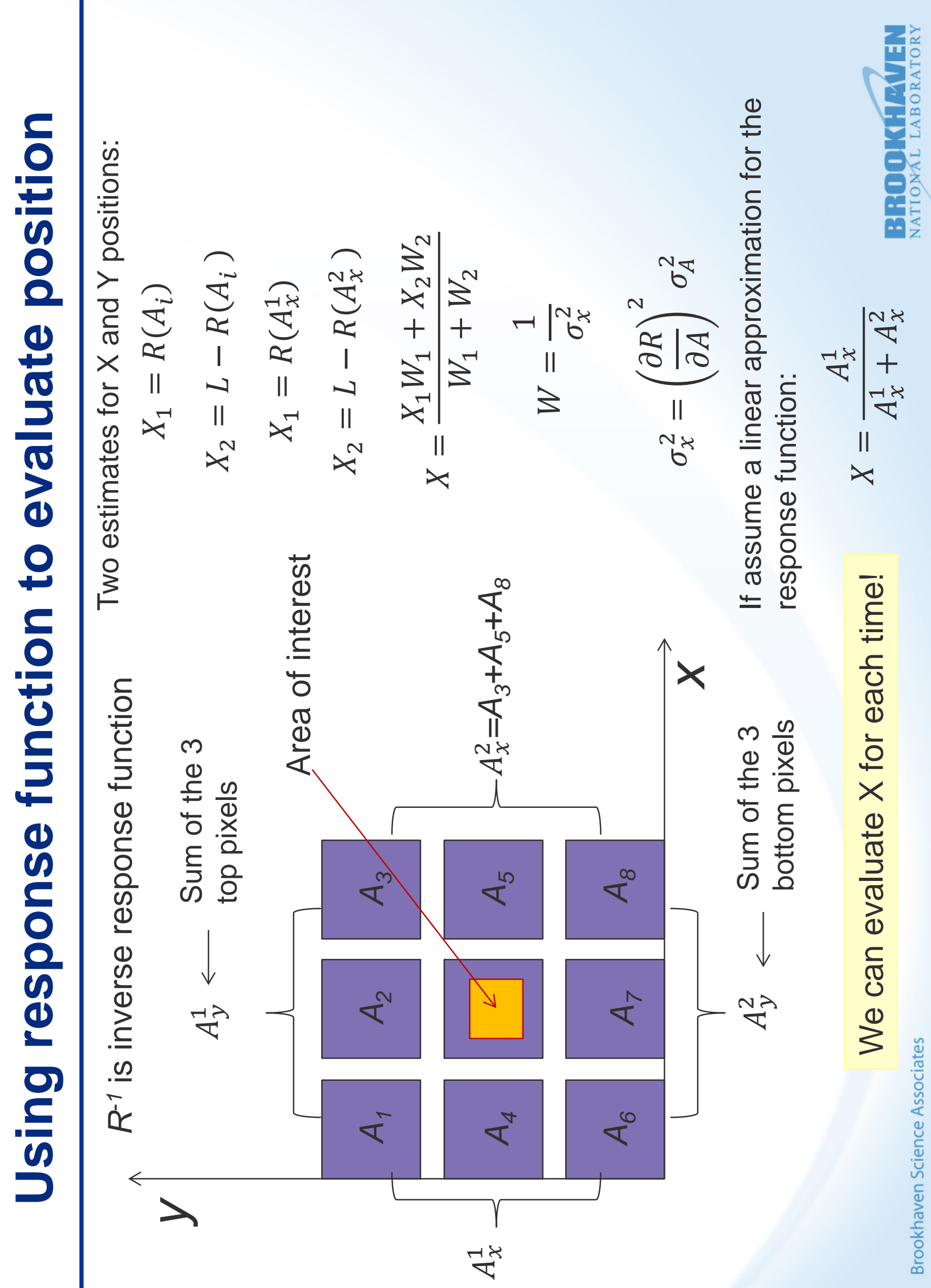



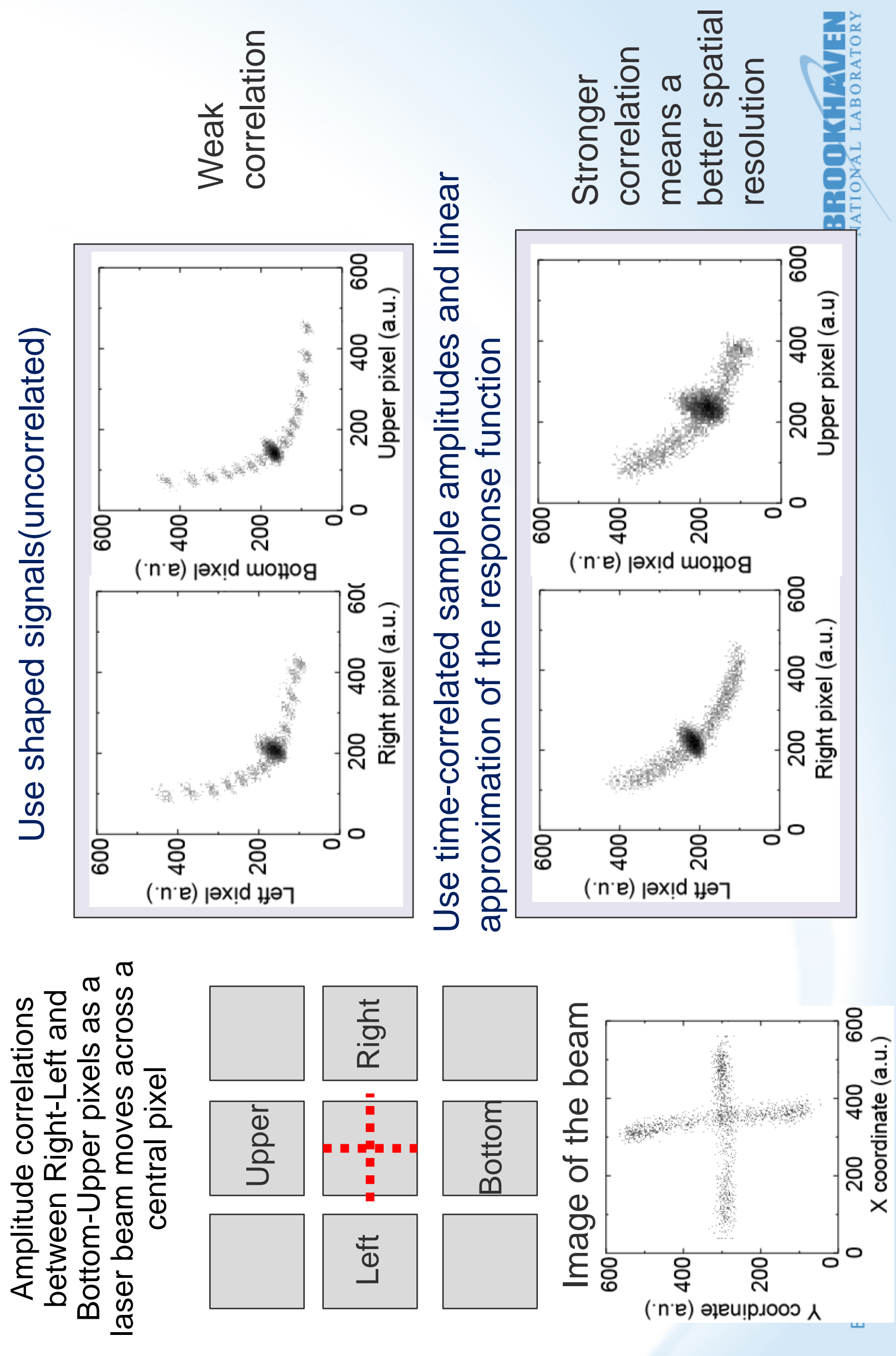


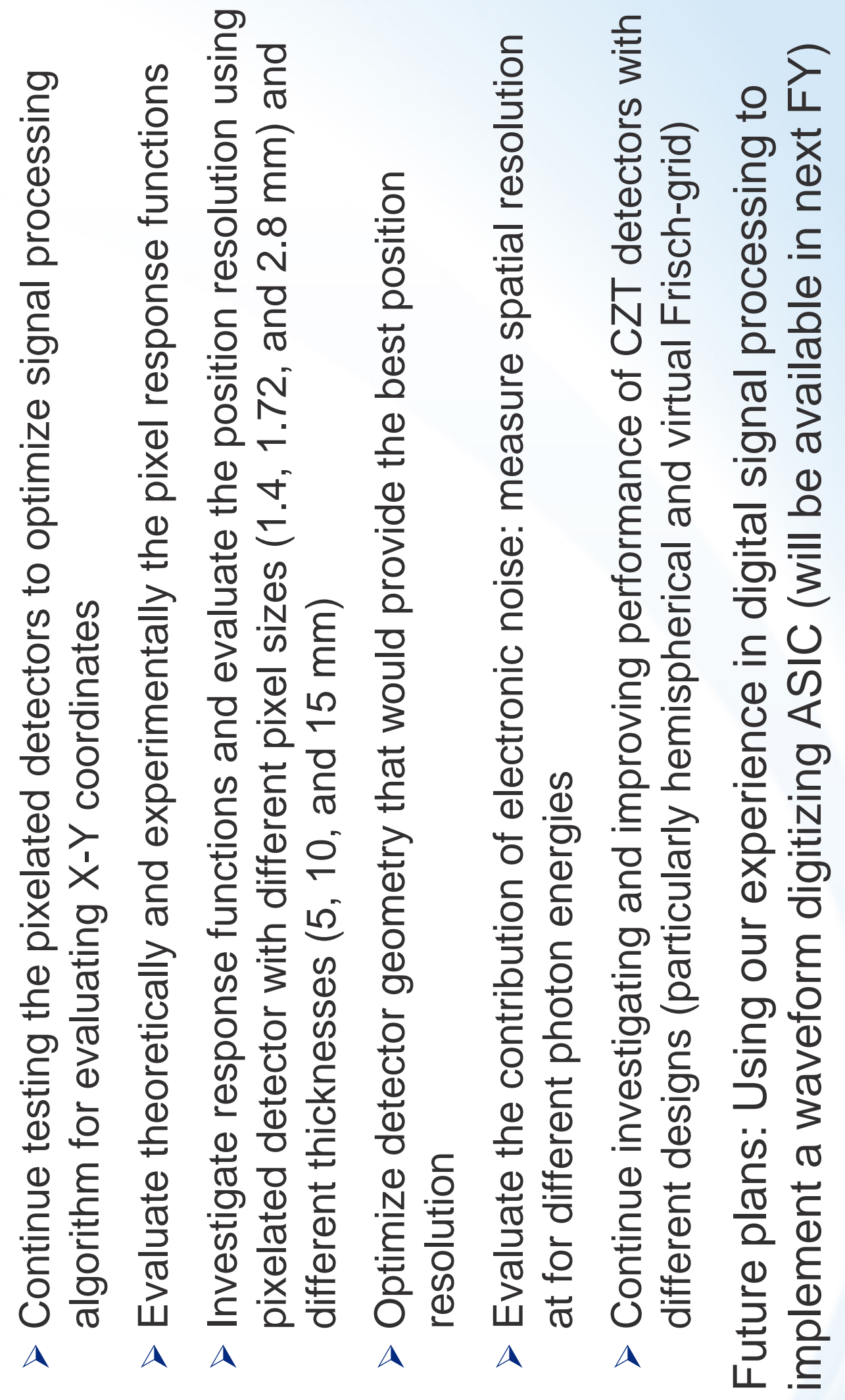

i) के के बे

v

\%

(1)

$\sigma$

0

8

0

d)

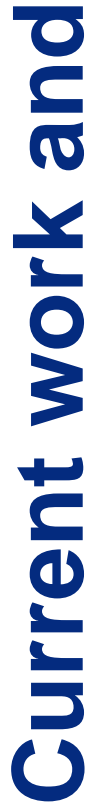
(ర) $r$ T U 


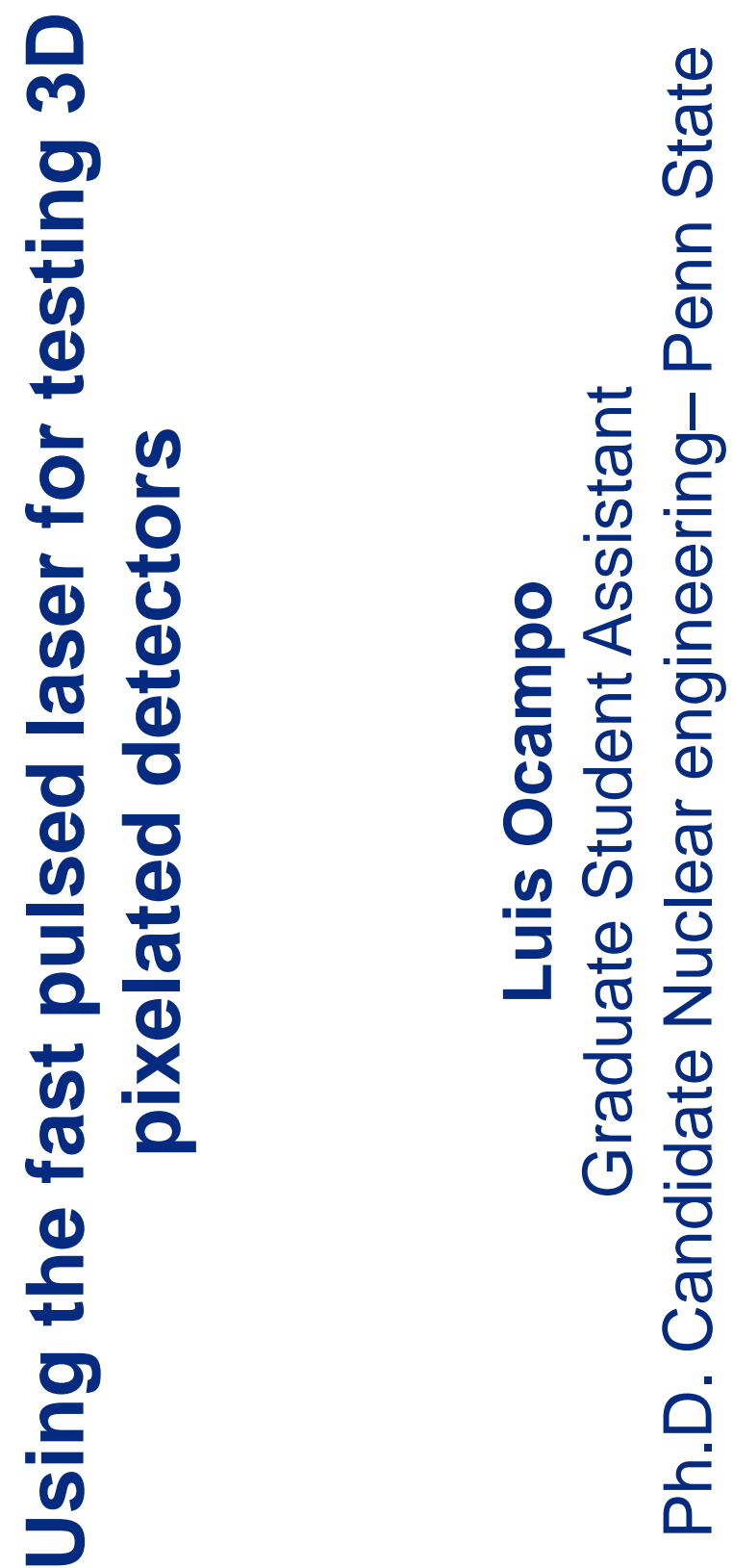




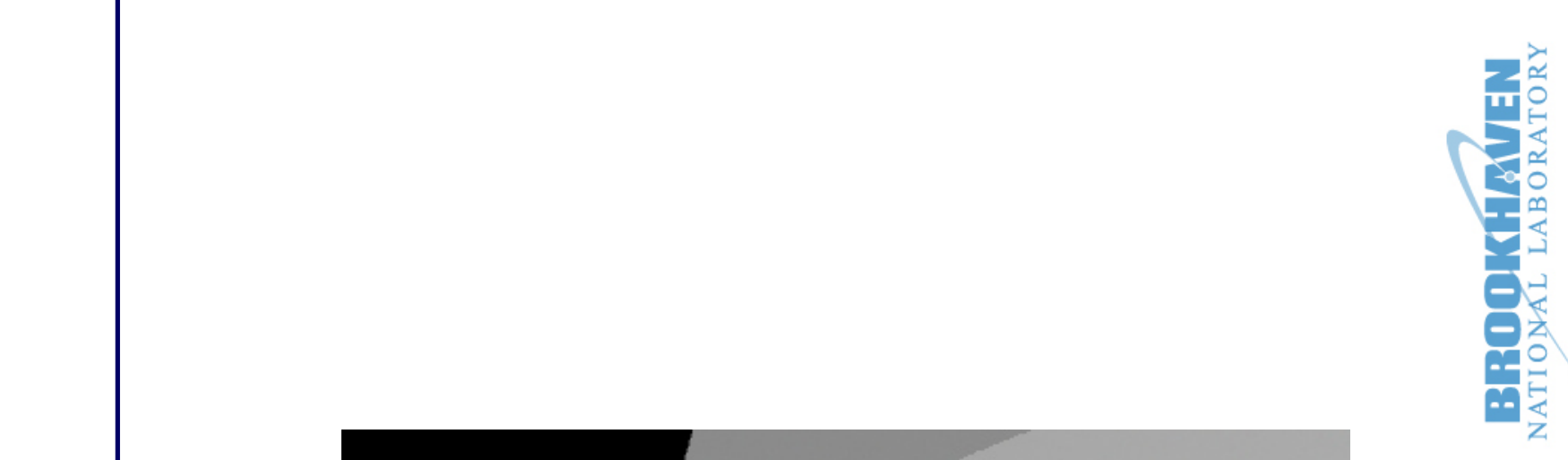
1 口

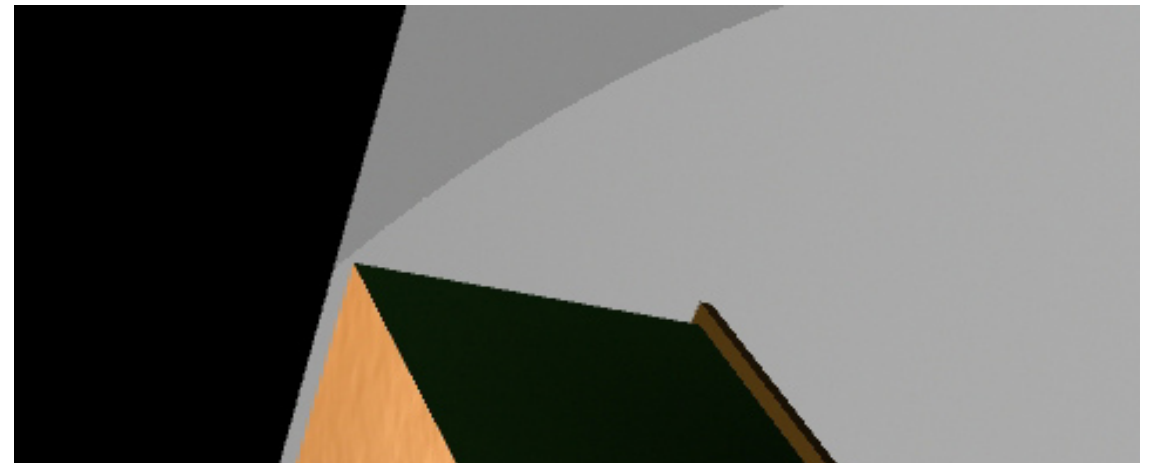

$\frac{N}{\omega}$

है

E

$N$

म

I

$\frac{0}{x}$

त 


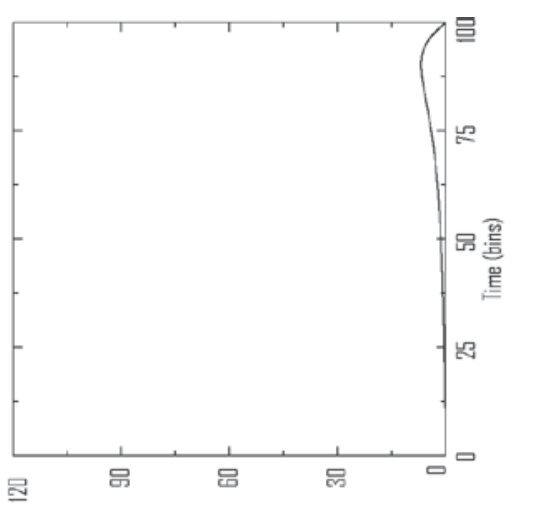

(aw) apru!|duy

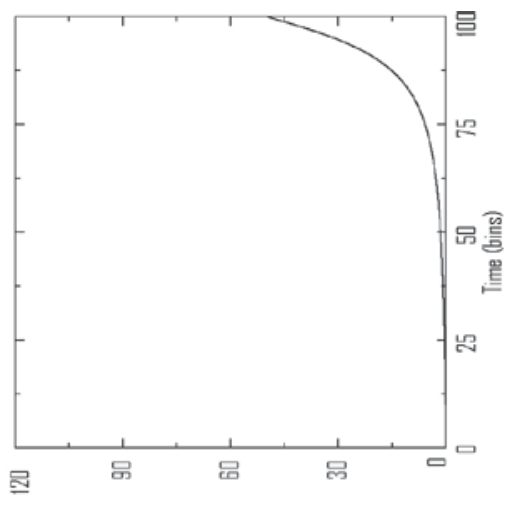

(Au) apru!duy

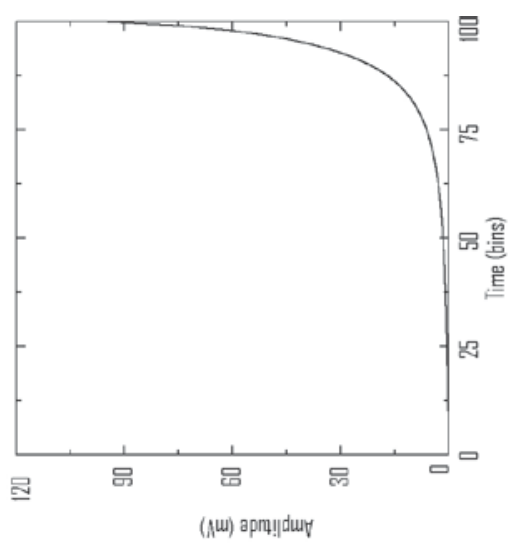

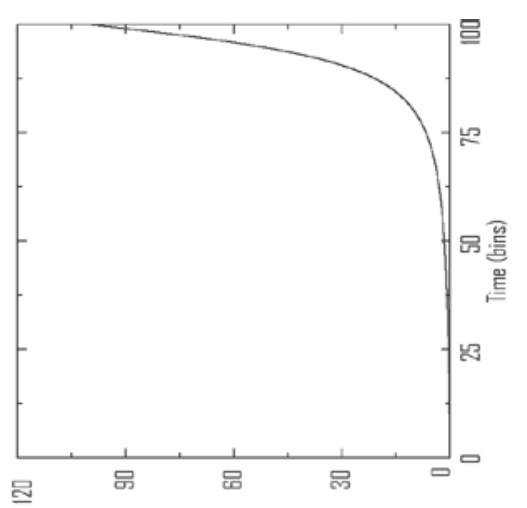

(nu) aprq!duy

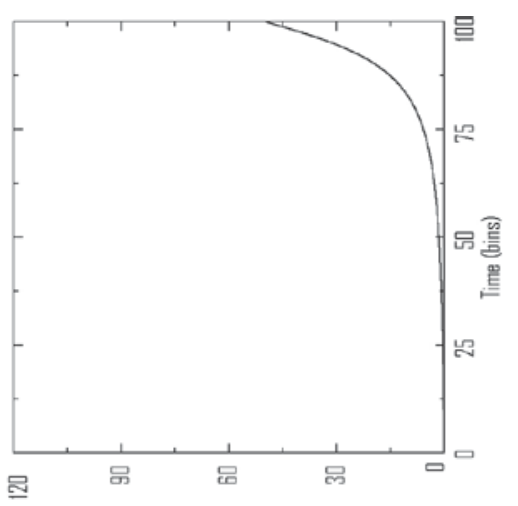

(Aui) apra!duy

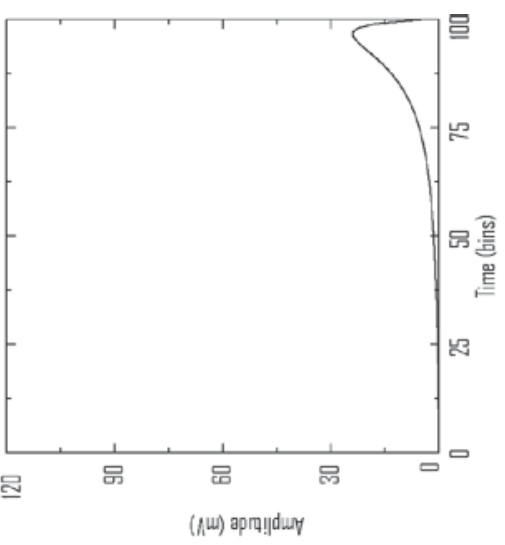

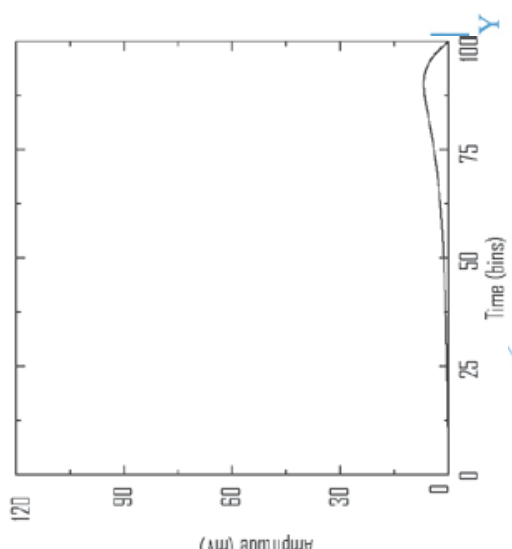

(Aui) aprn! duy
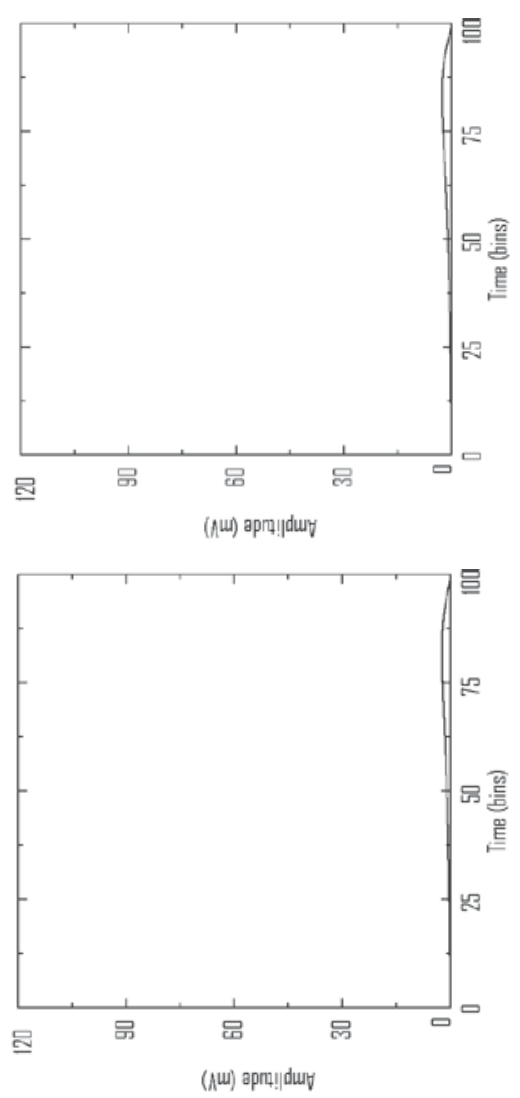

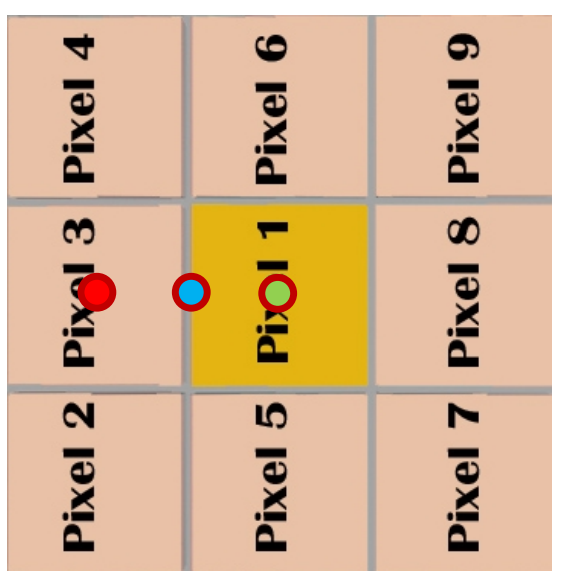




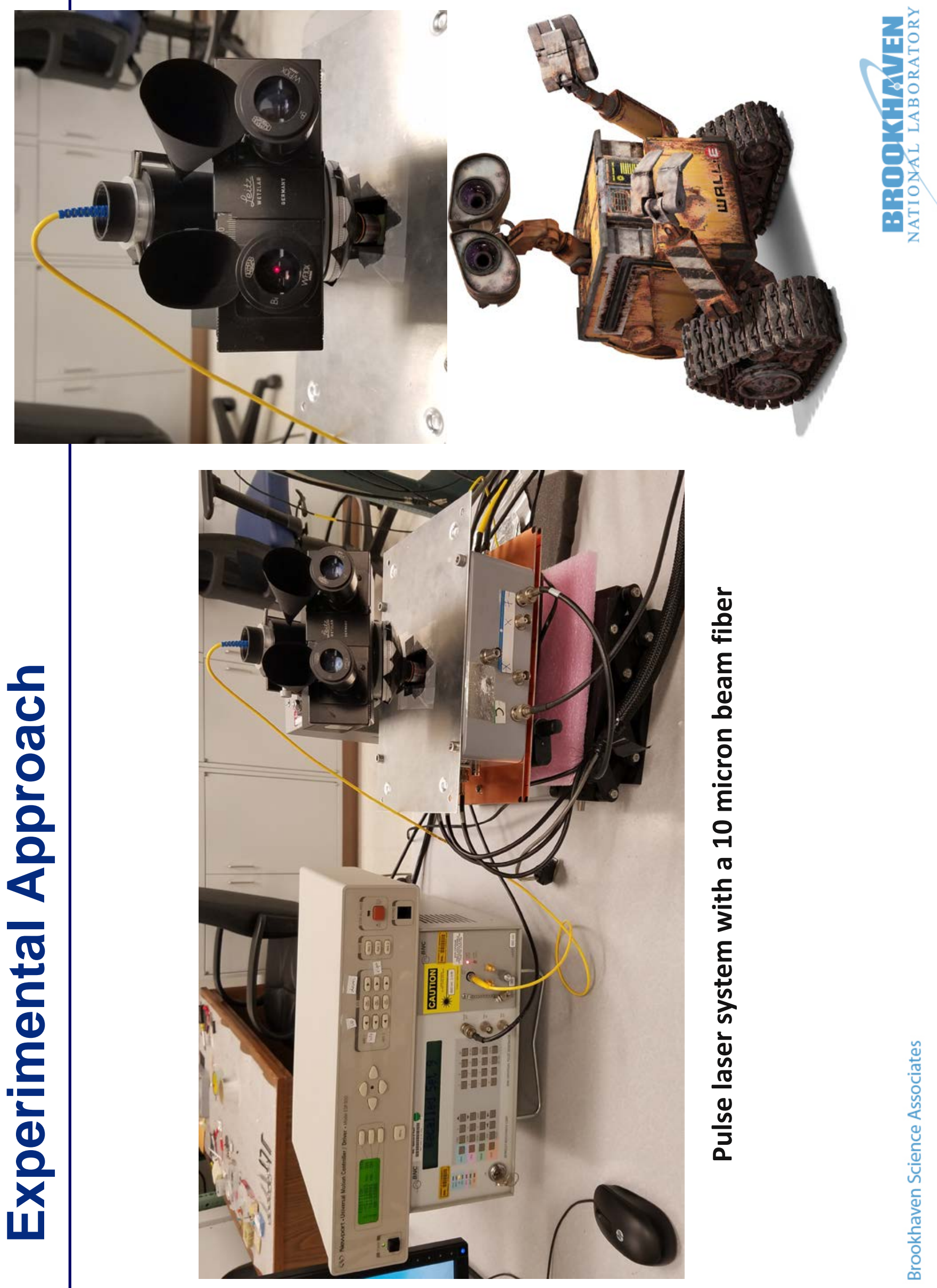



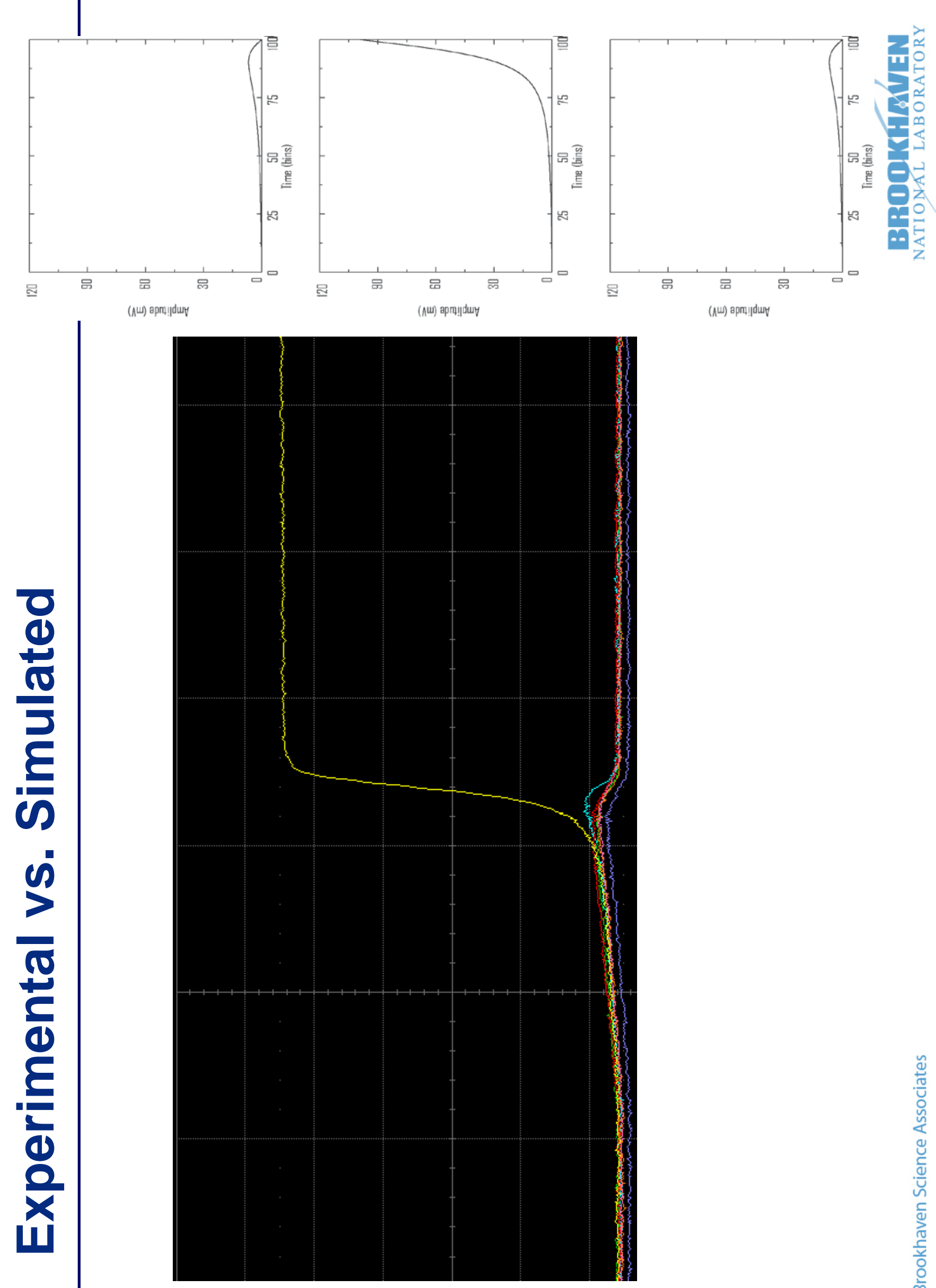

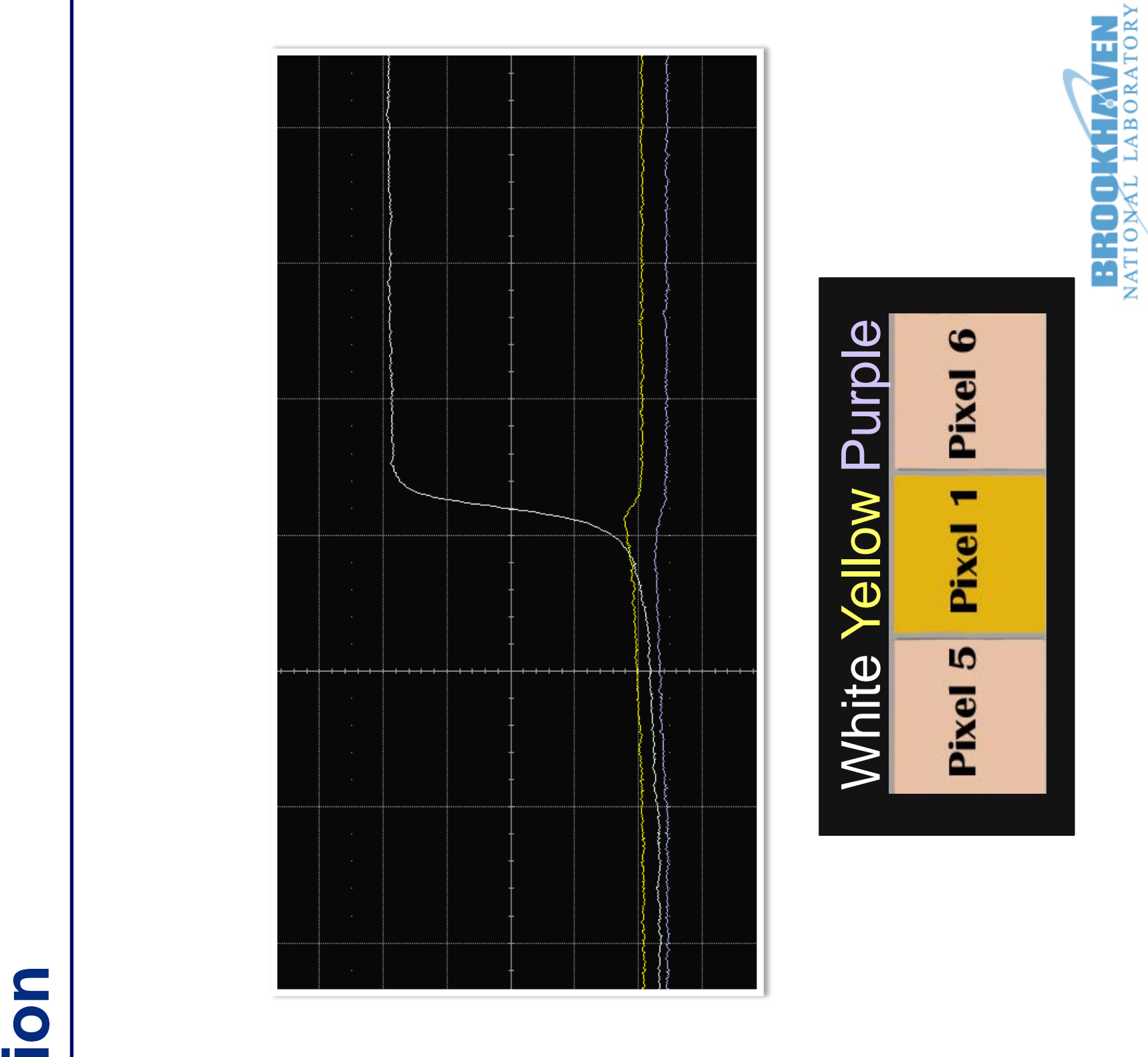

T15

0

(10)

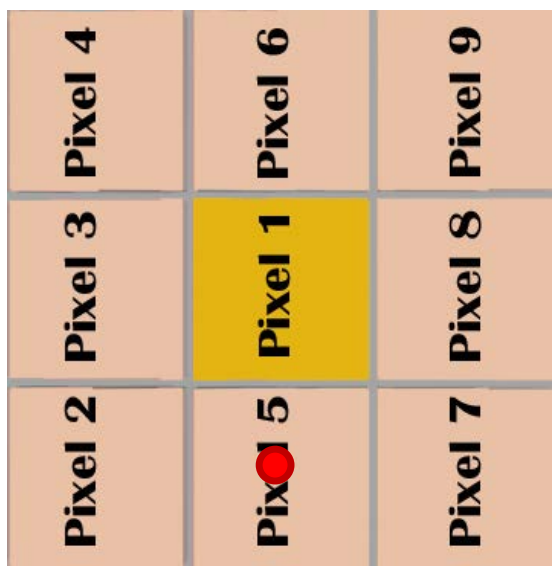




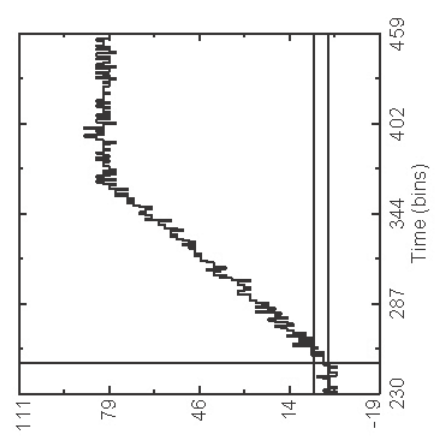

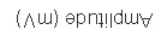

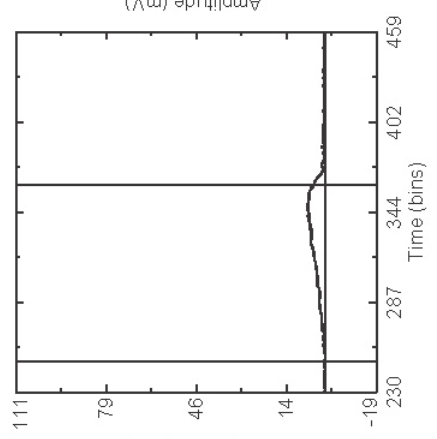

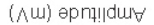

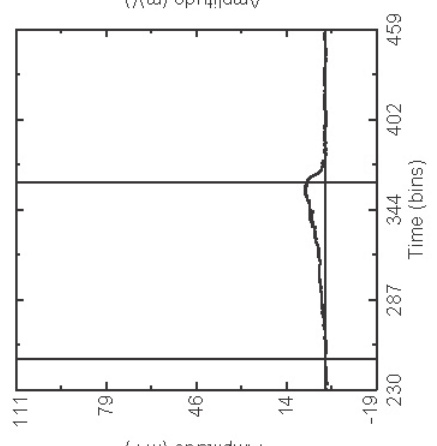

( $\wedge$ ) әpn!!!dur

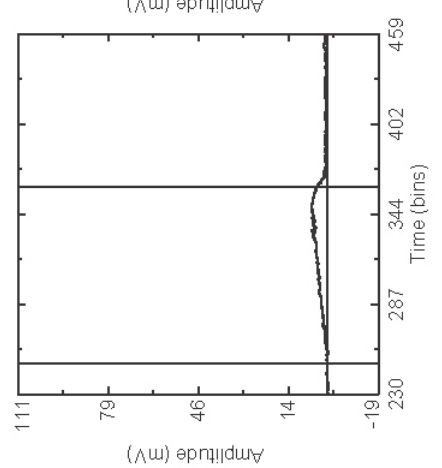

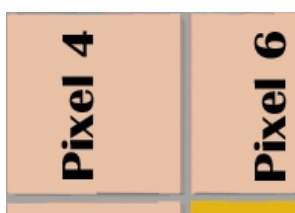

$\infty$

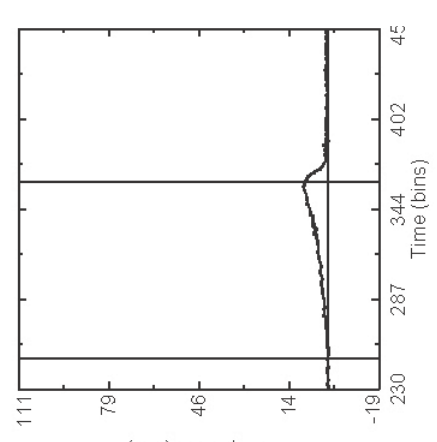

(^u) әprı!!dury
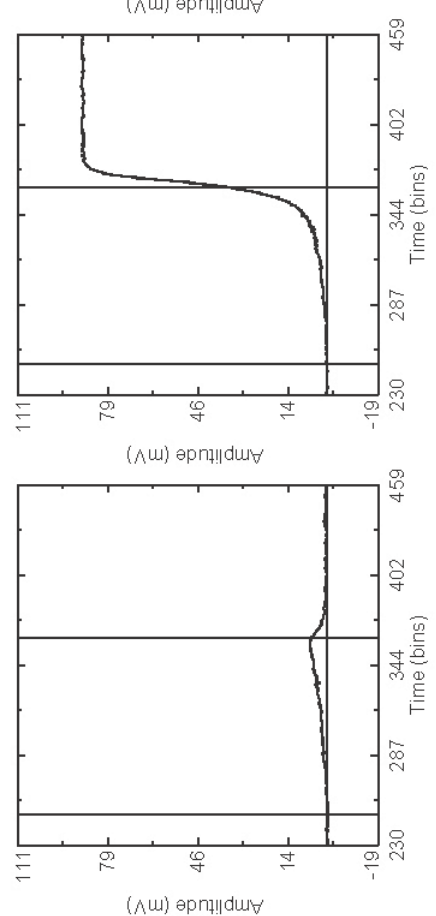
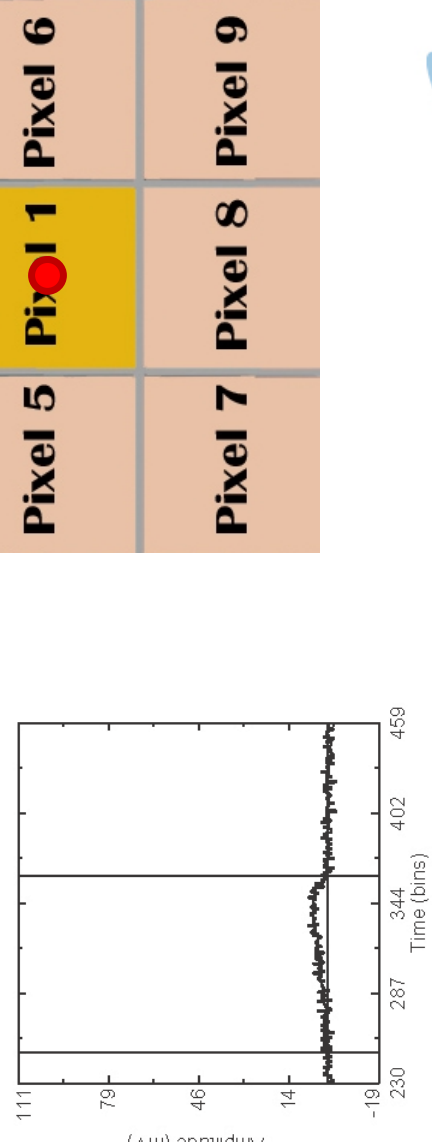

(^u) әpпฺฺ!dur

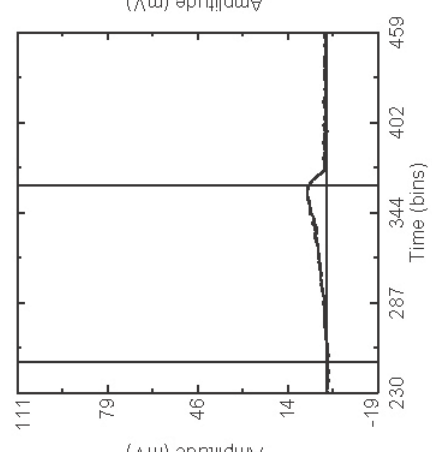

( (u) әpni!ldur

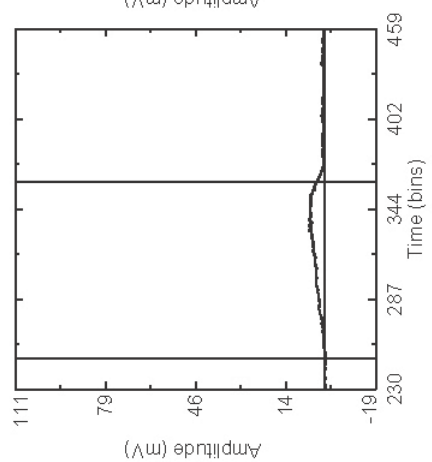



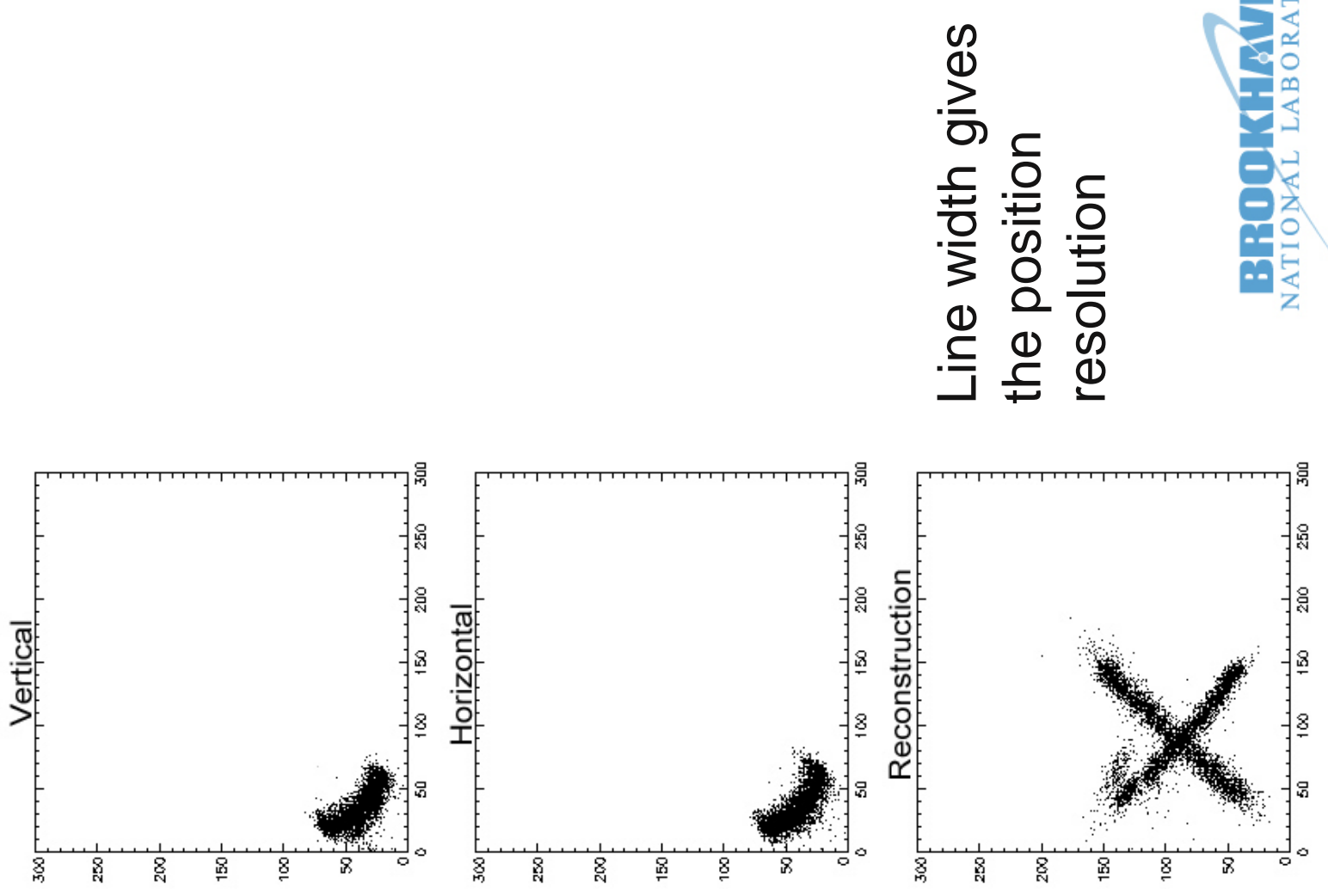

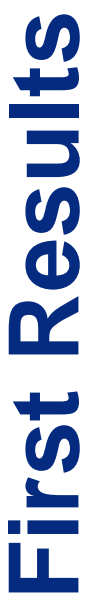
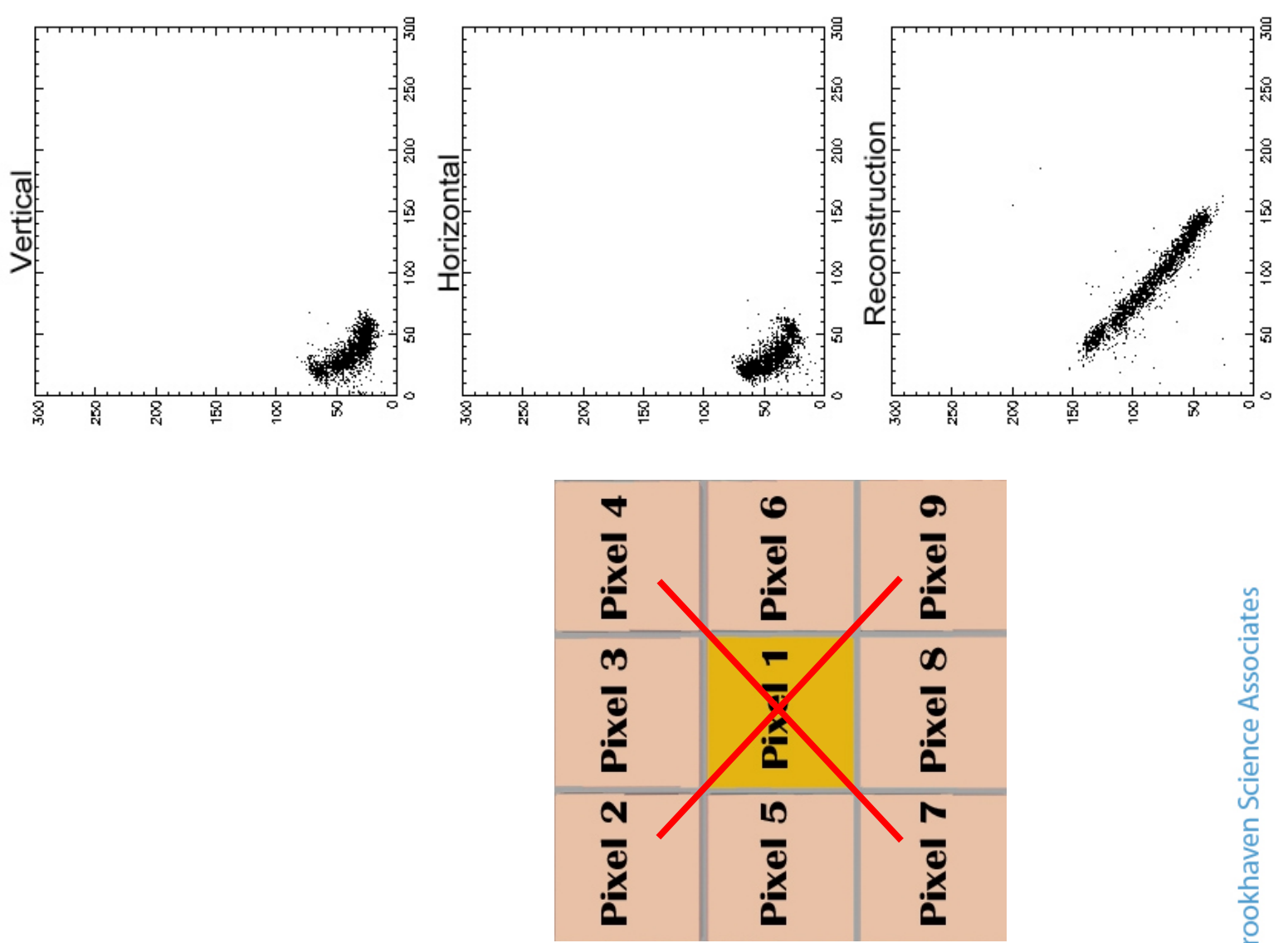

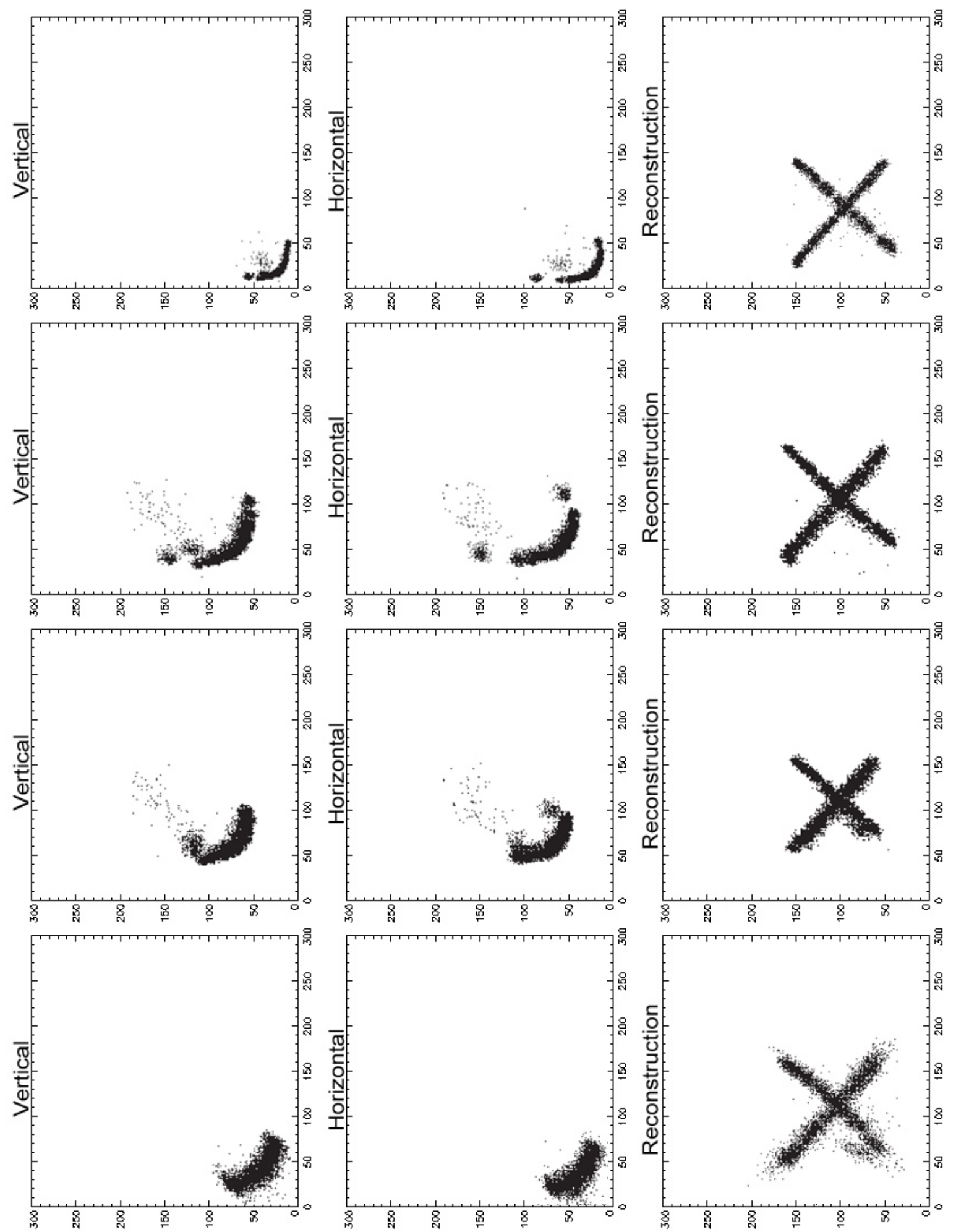

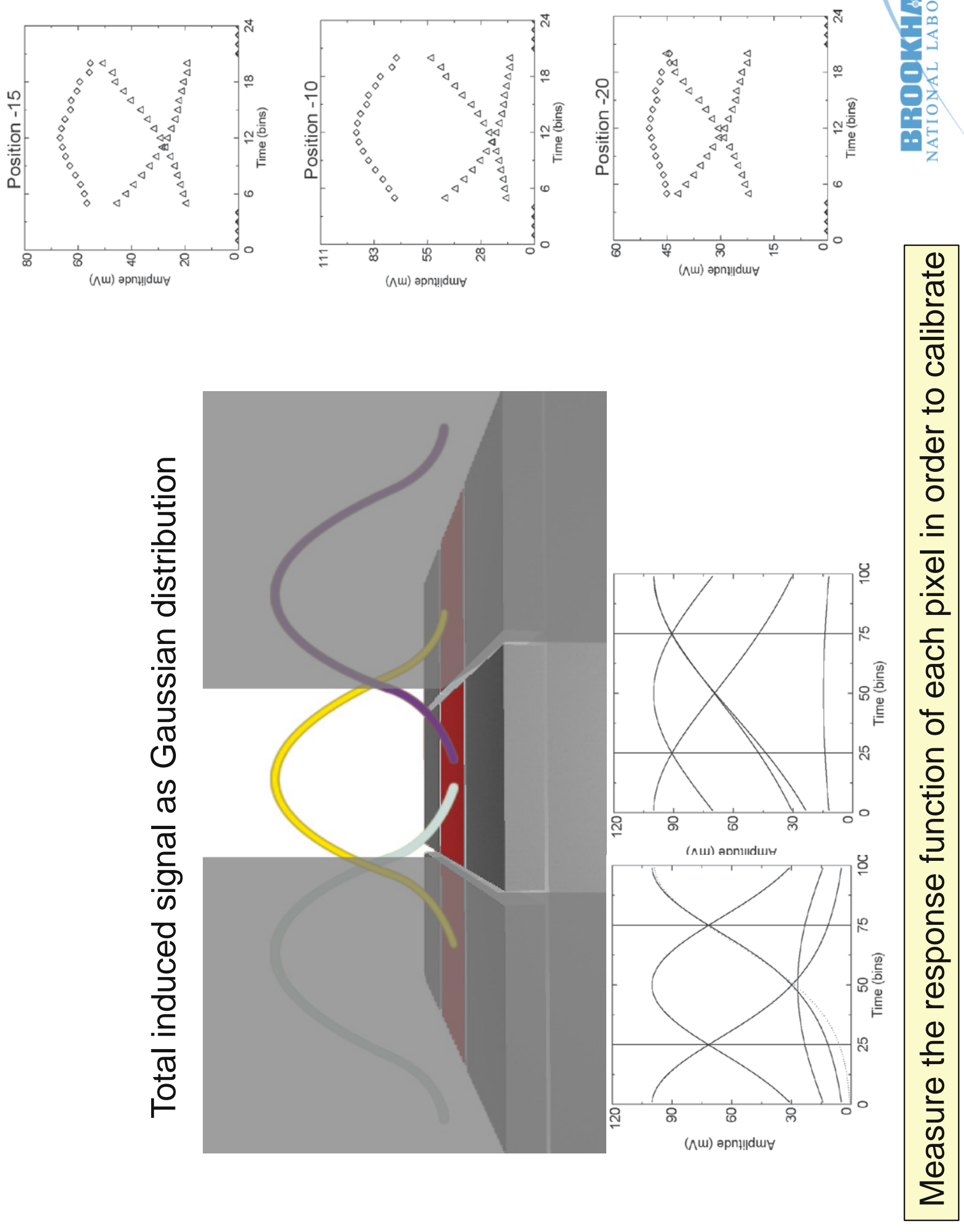


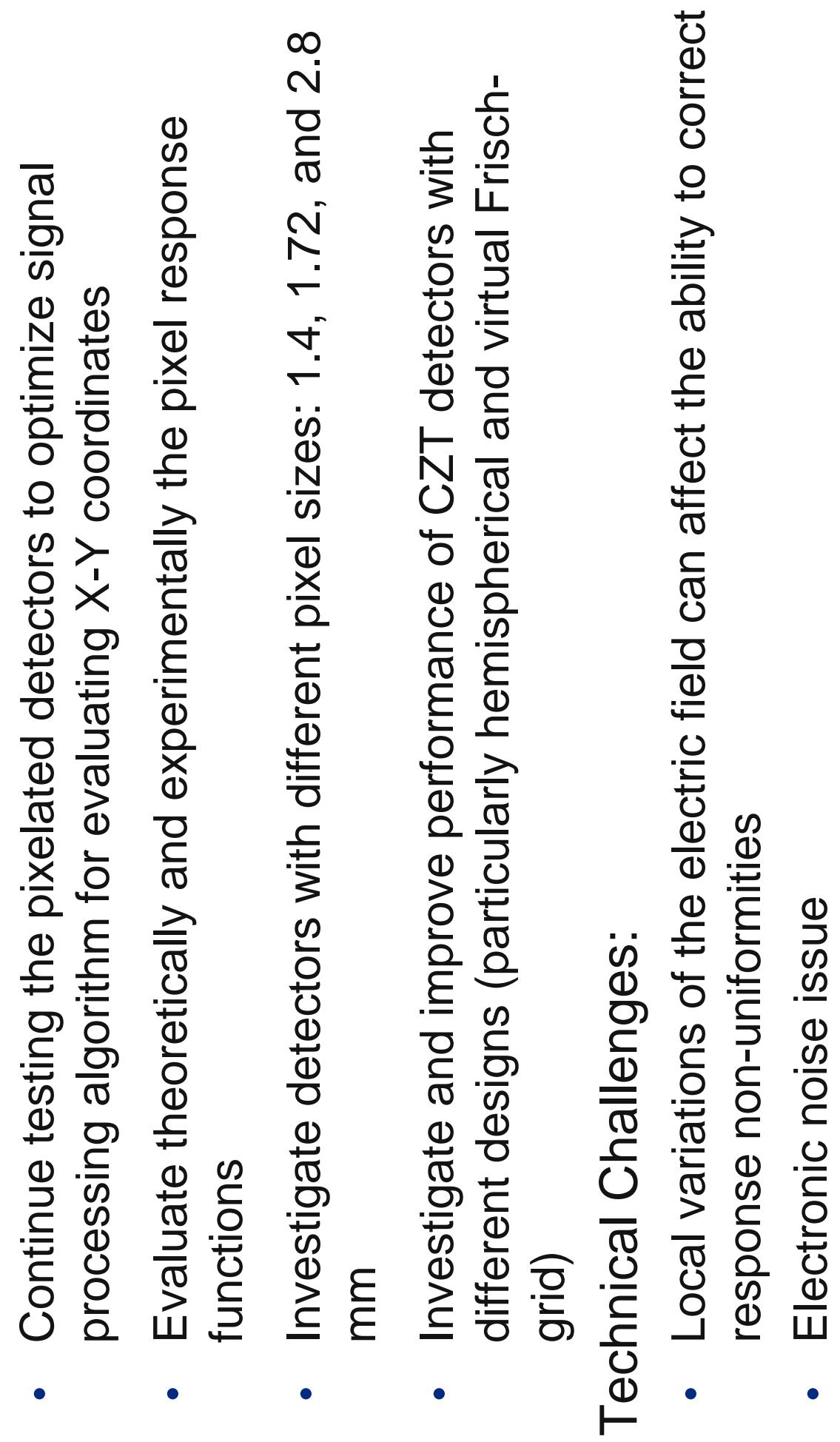




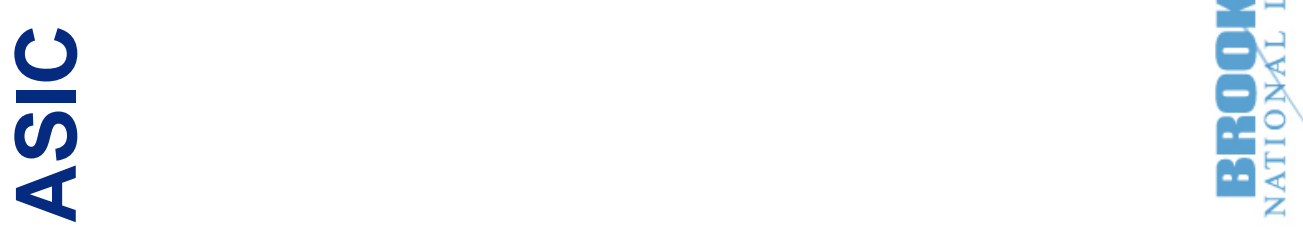

ค

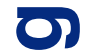

.

N

0

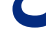

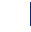

E

4

(a)

8

$\sum$

4

$\frac{1}{0} \cdot \frac{5}{6}$

ㅇำ

루름

0 ช

क ह ह

(1) 를

E

(1)

E

0

0

(1)

(1)

0 


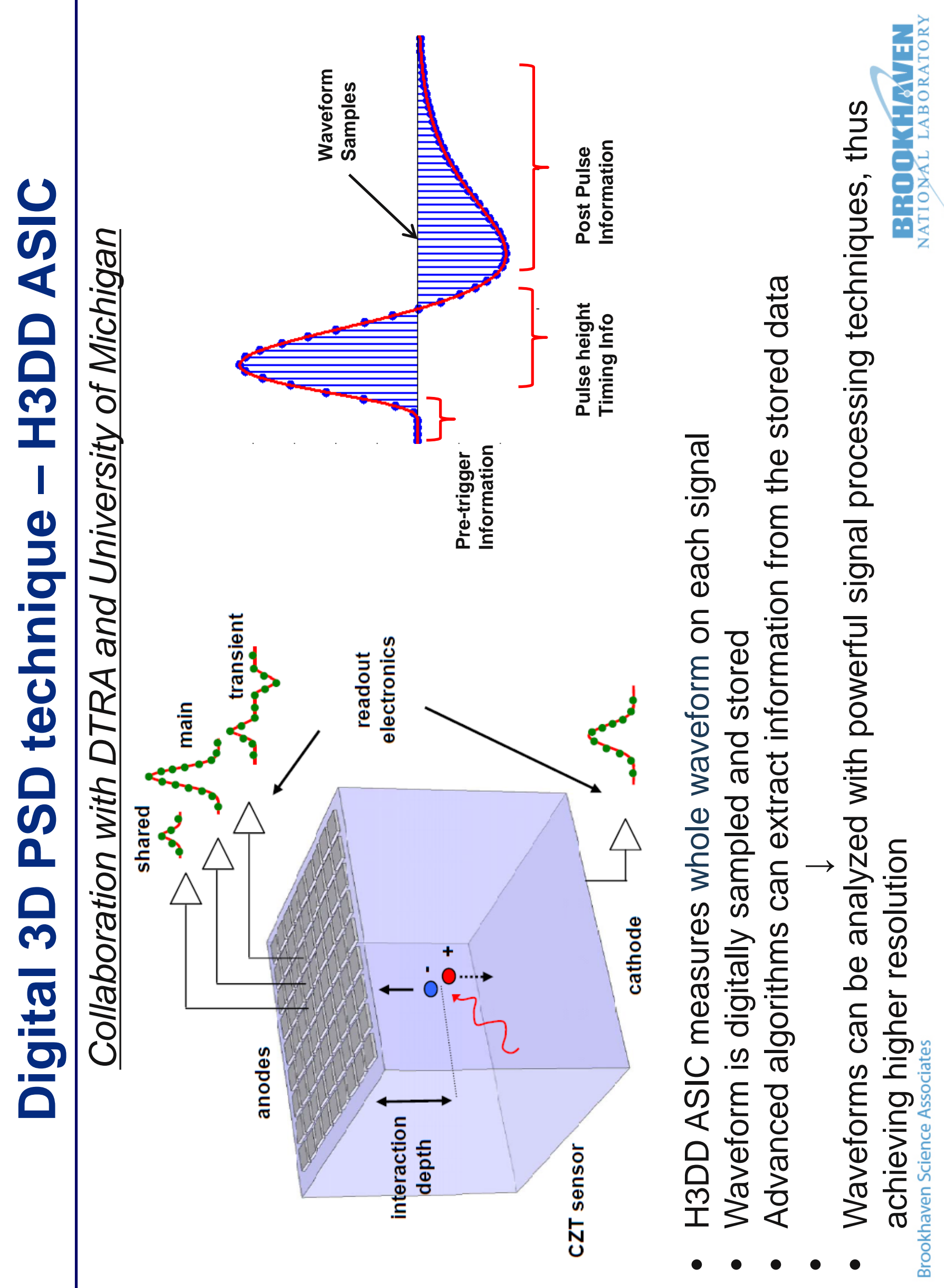




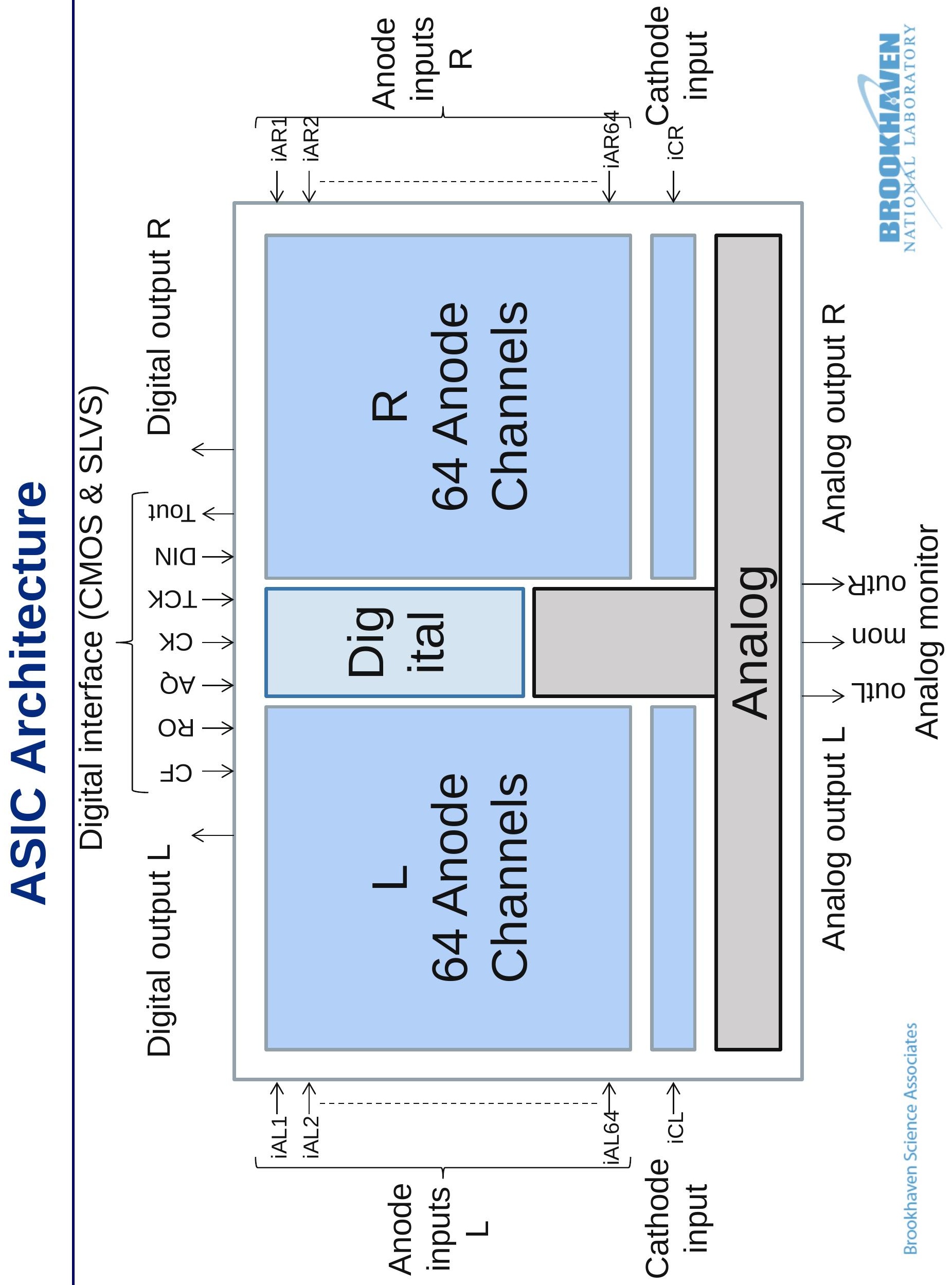




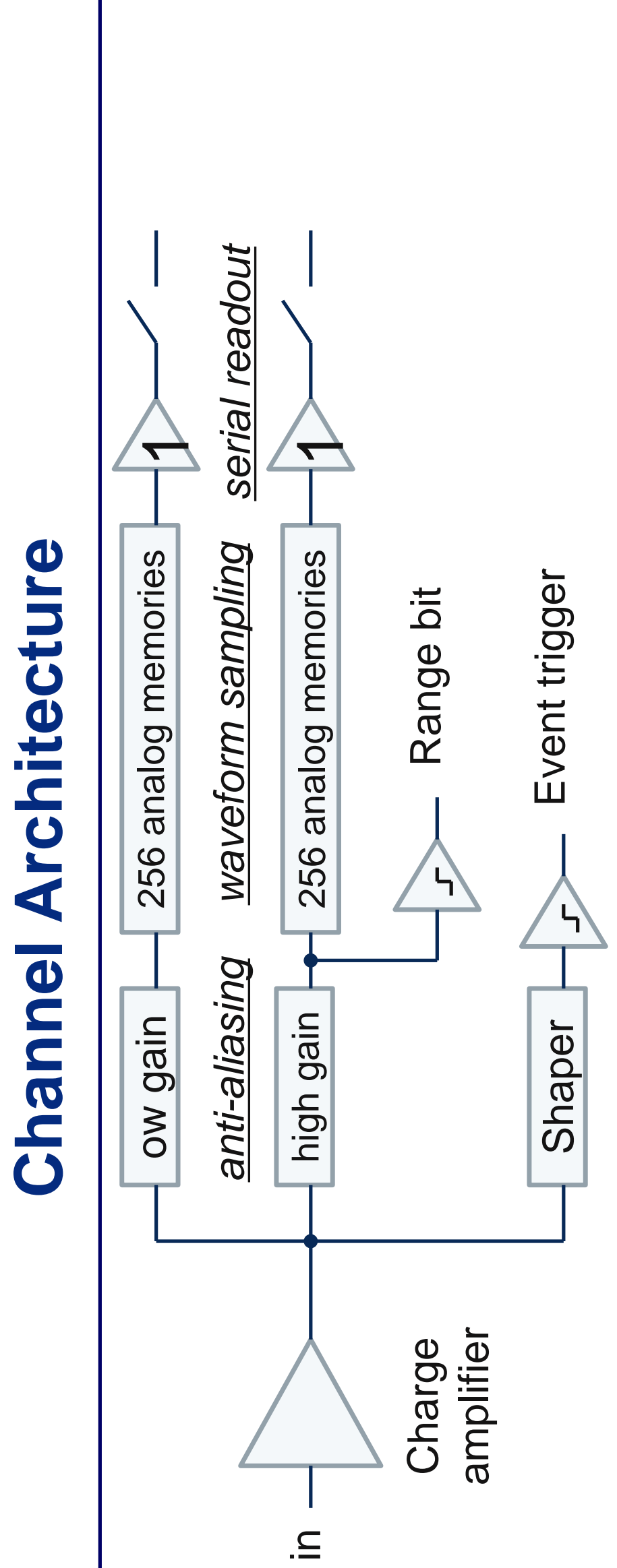

으

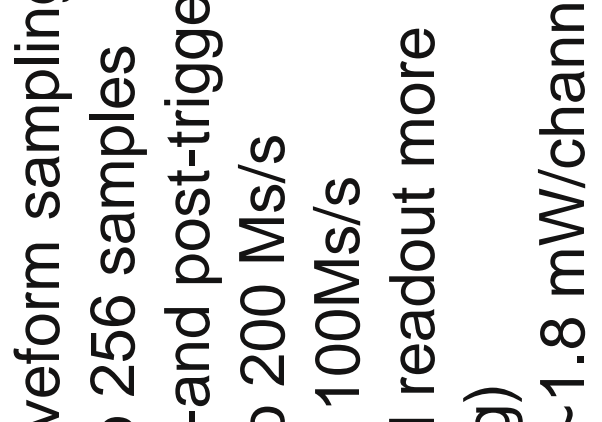

สิ

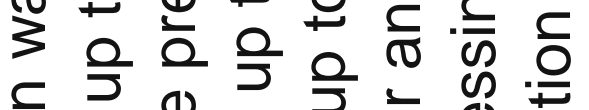

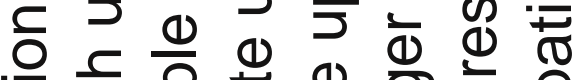

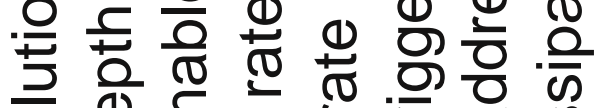

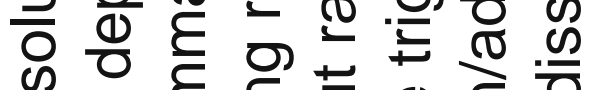

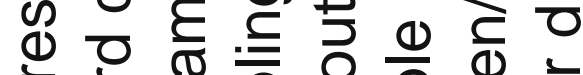

亡 응 을 을 을 잉

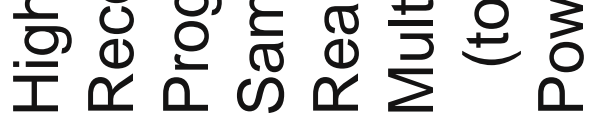
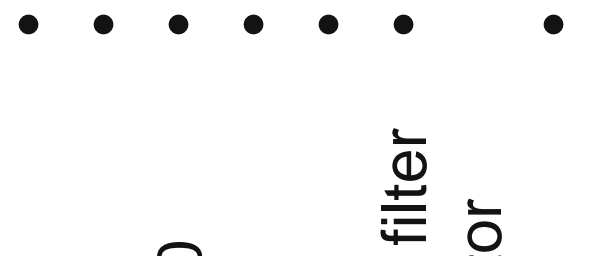

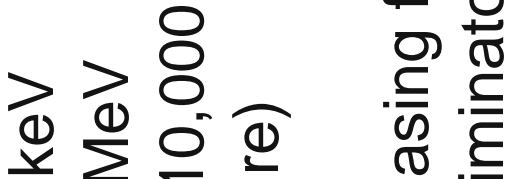

न $\sum_{0}$ 光

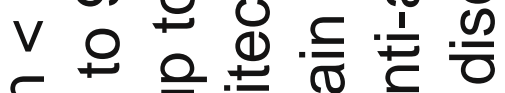

응 윽 产 ฮ

인

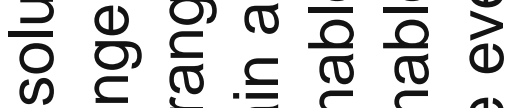

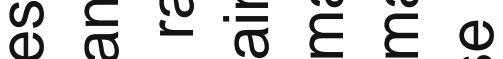

- U U O E E U

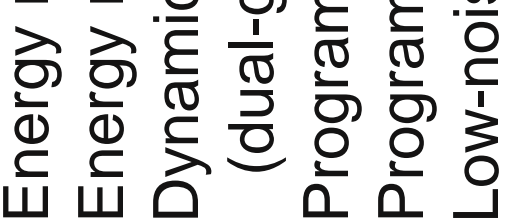




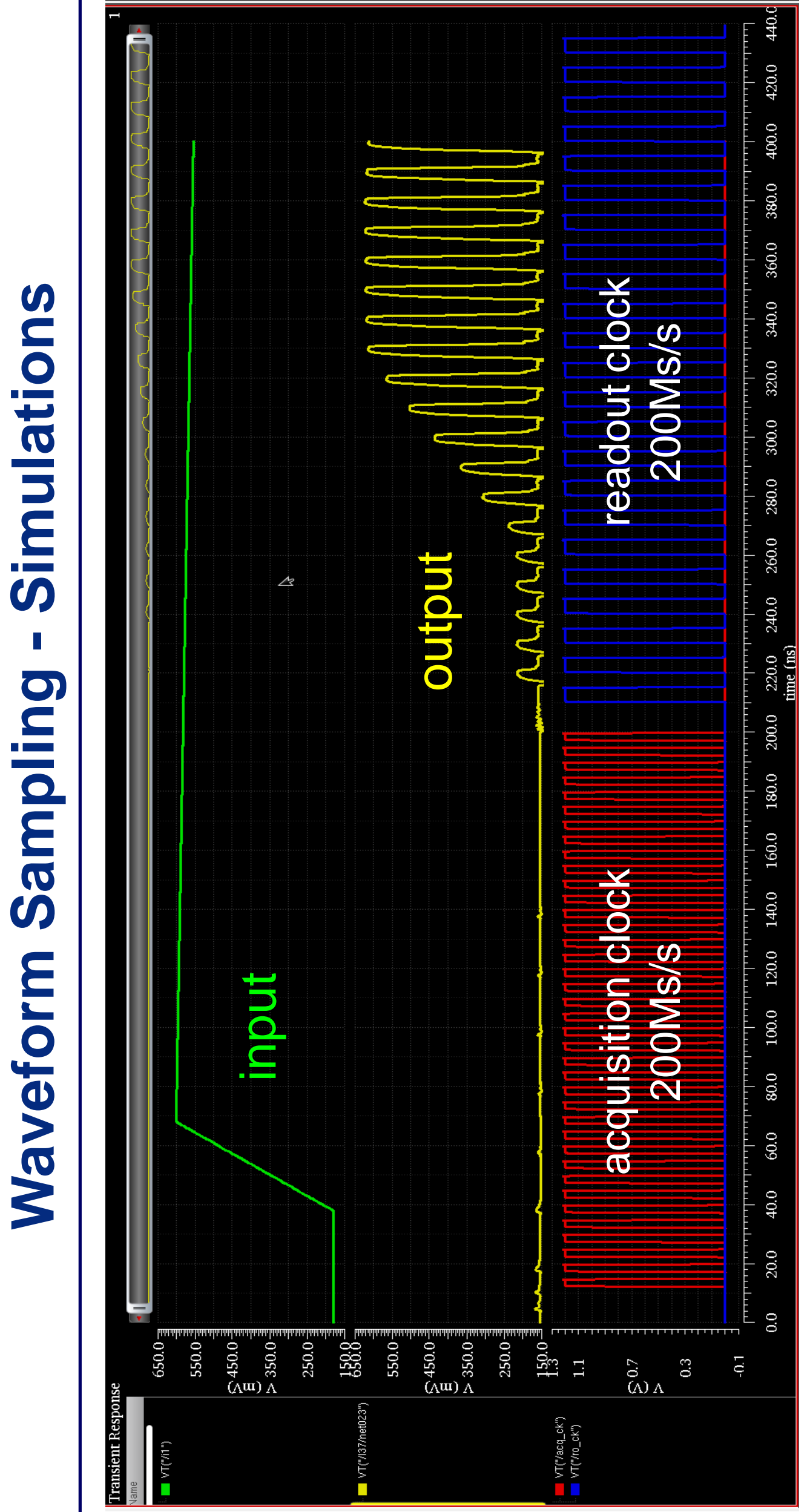




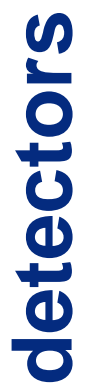

战

을

ช

$\pm$

5

4

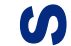

올

(1)

$<$

10

5

os

른

으

ज

ชั

(1)

ㄴ. 


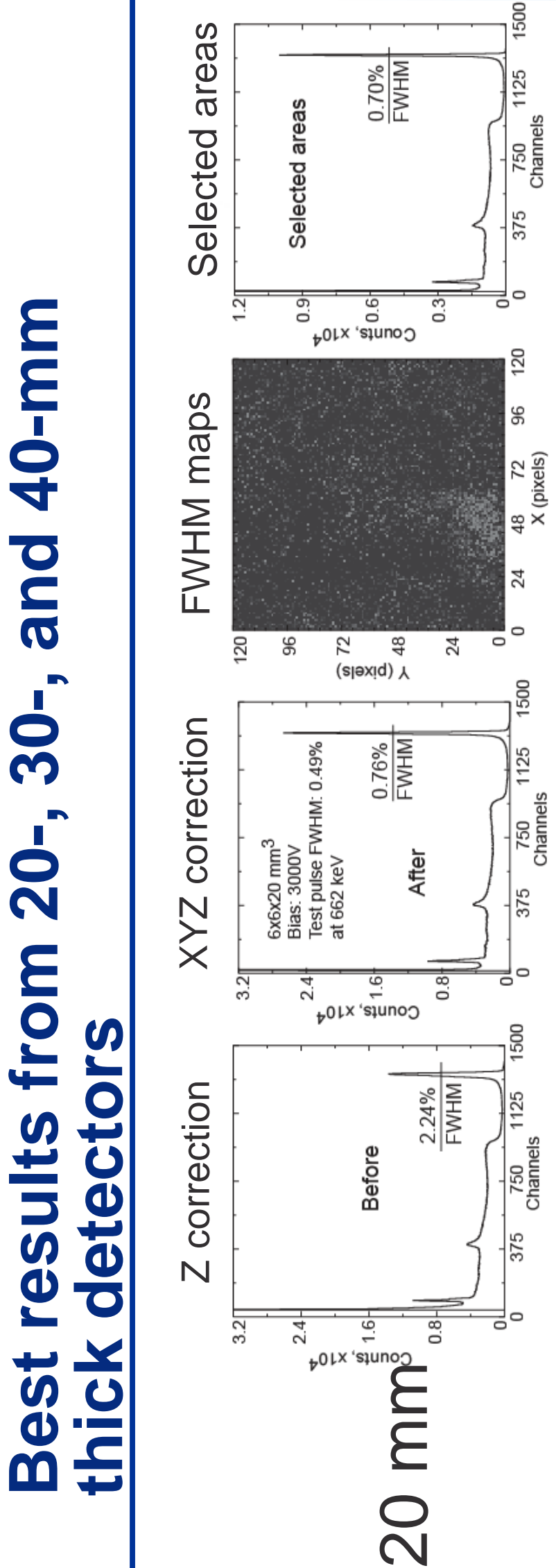
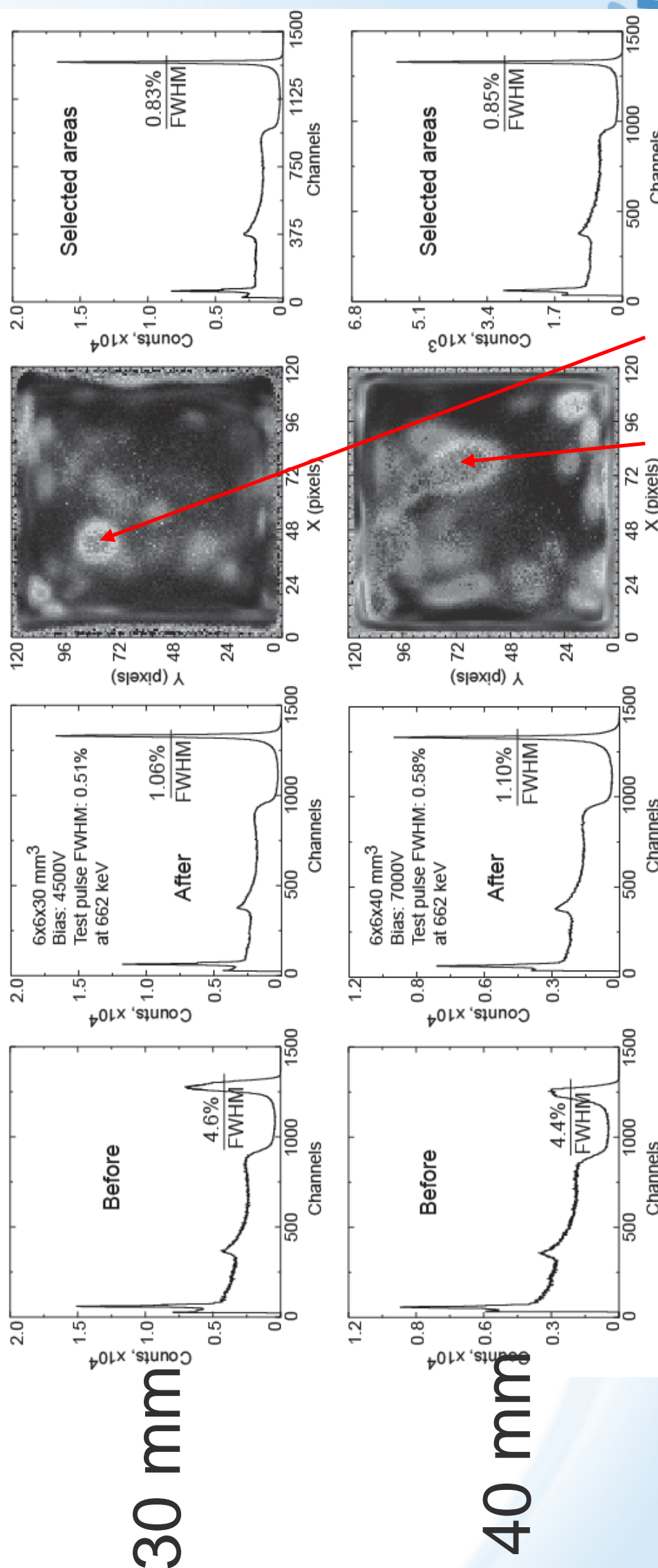

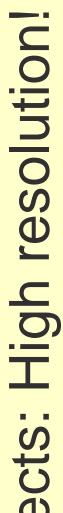

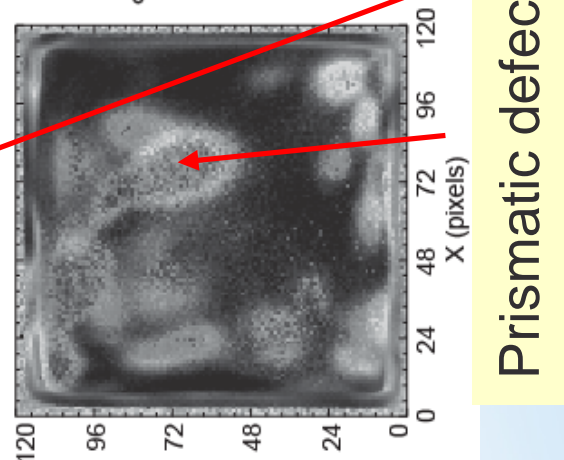

(s|əx!|d) ᄉᄉ
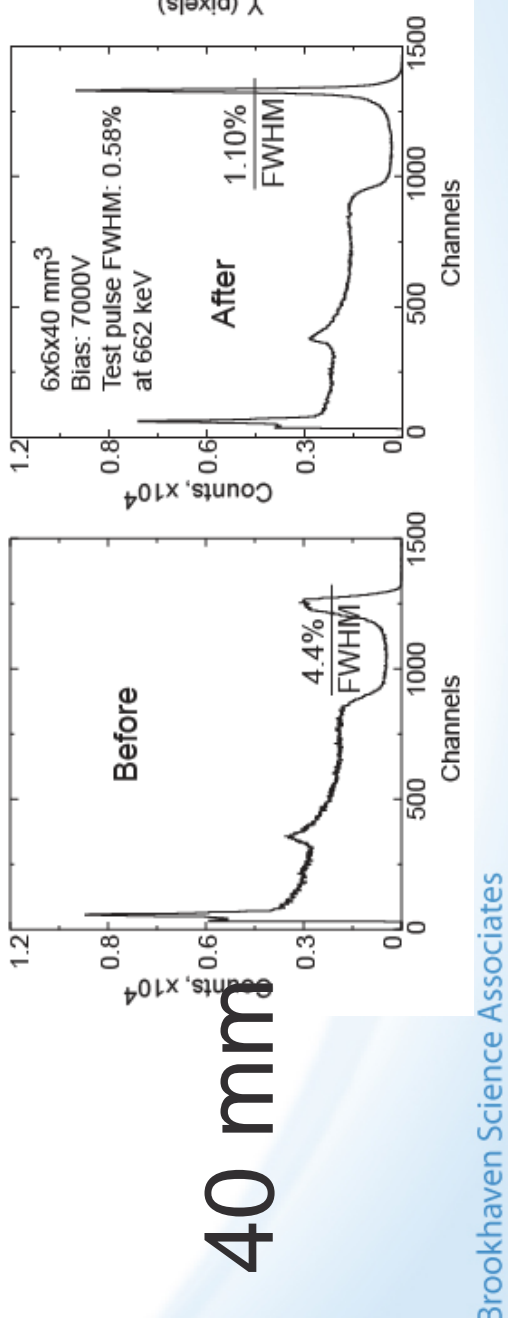


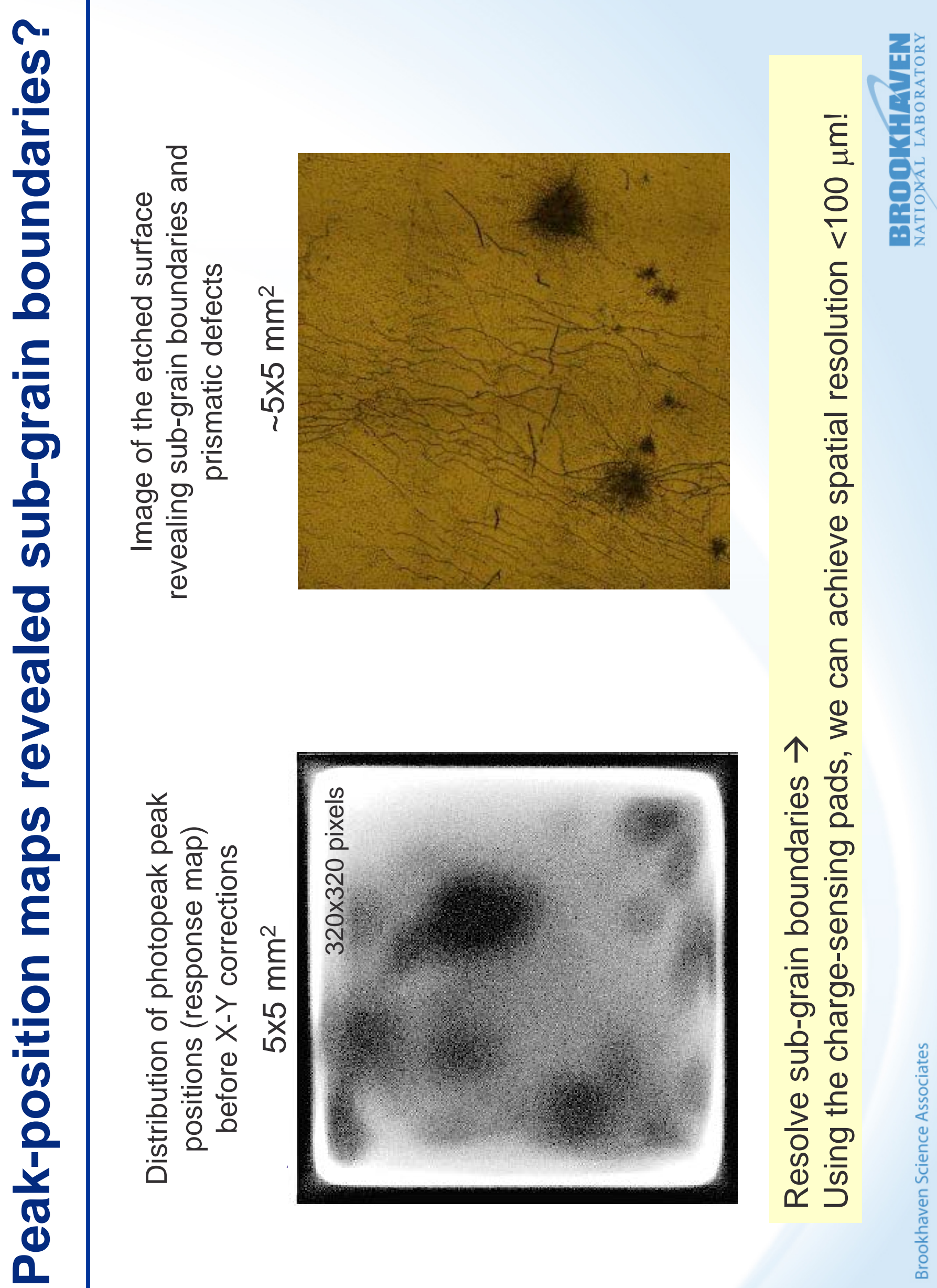



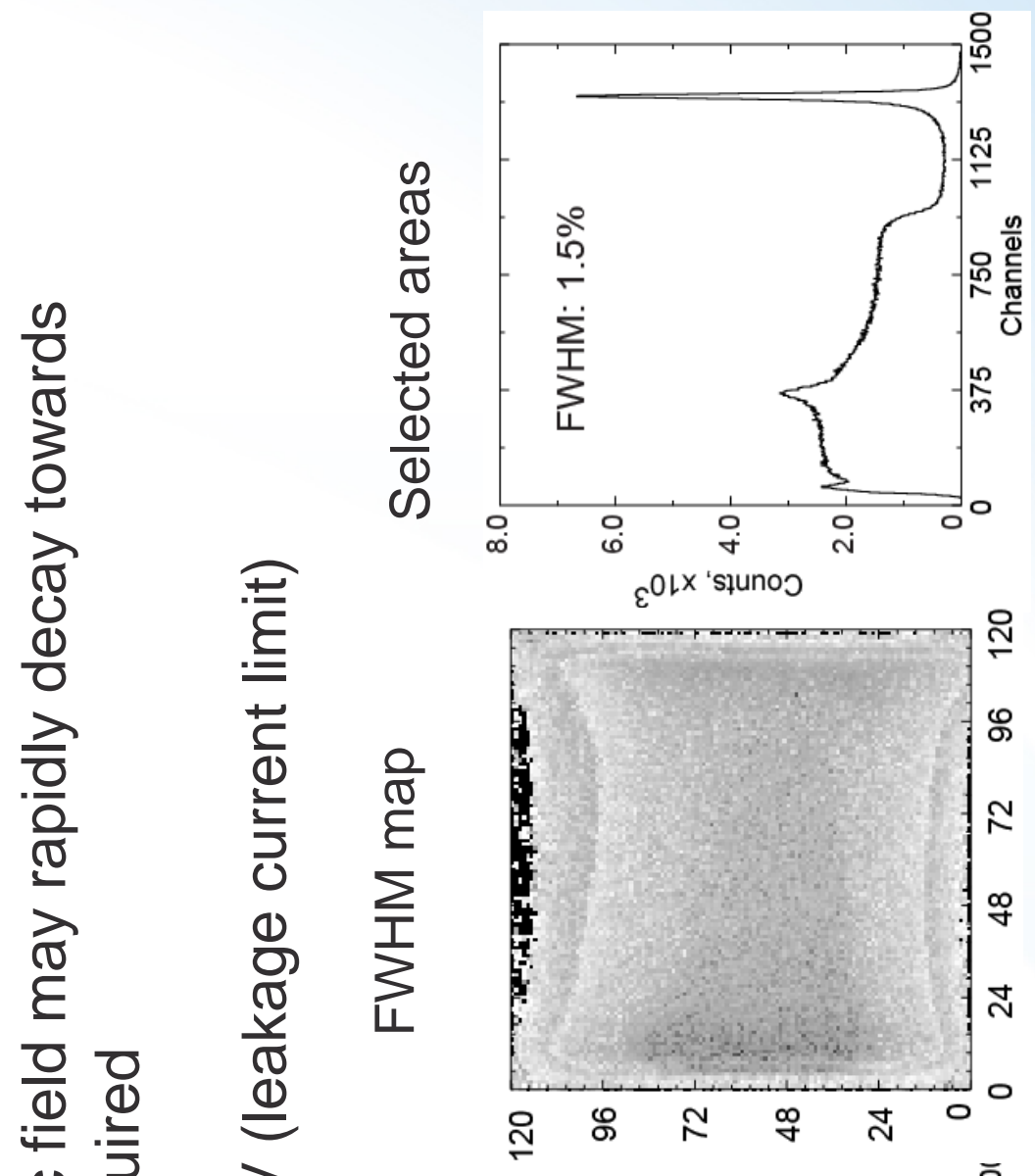

으 궁 >

넌 요용

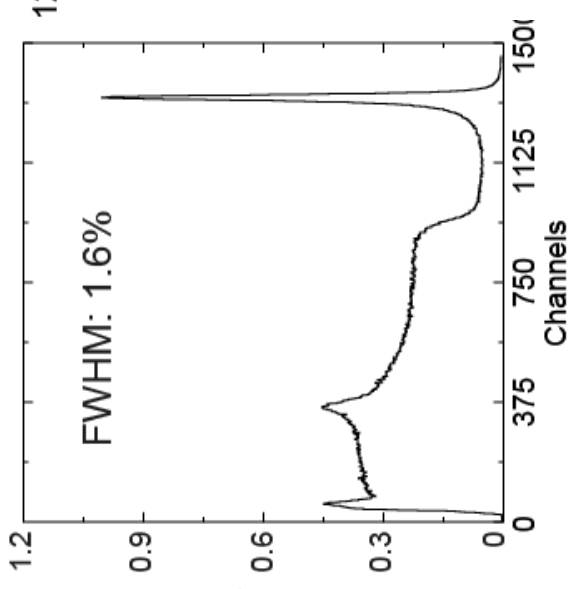

(1) $\frac{\pi}{2}$

告

넝 동

密

O)

ब.

克个 高

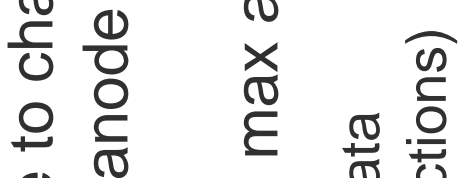

ब1)

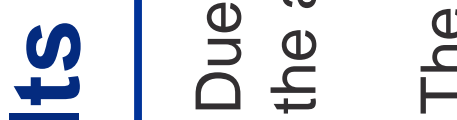

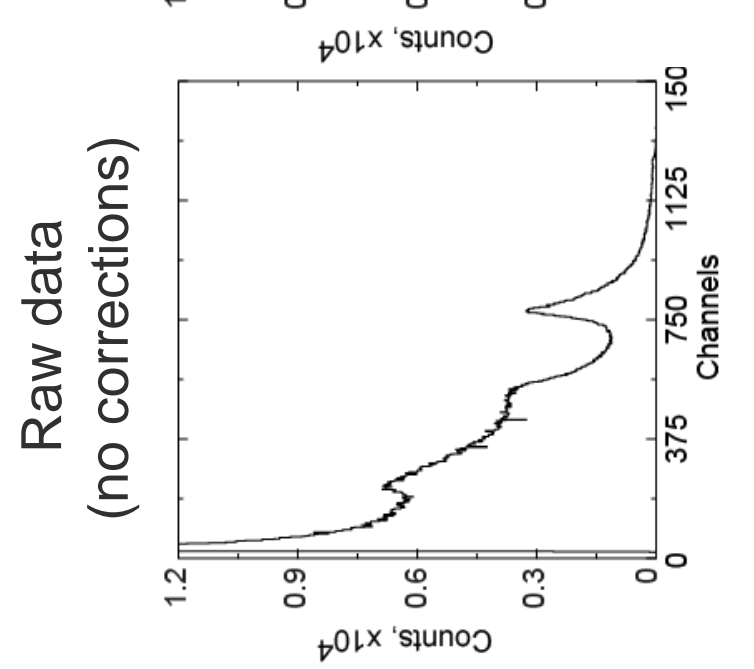

잉

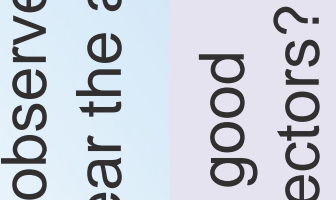

동

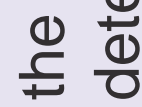

(1) $\frac{0}{0}$ 단

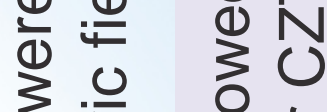

苍 क

$\frac{1}{0} \frac{0}{0}$

更 0.

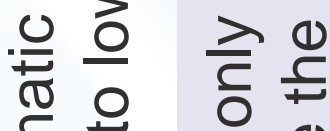

$\varepsilon+0$

뜬 음 음

흠ㅎㅇ 음

个㐫 导 ठ0

$\varepsilon \stackrel{0}{\underline{\underline{y}}}$

흠 응

亭 읻

ํ.

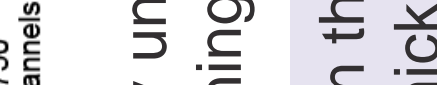

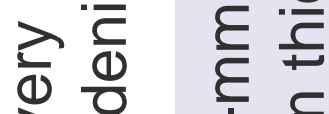

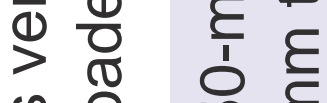

응 ㅇํ है

으 웅

ส․

हत त

$\sum$ \&

m i

䓀

,

$\therefore \frac{\pi}{z}$

(1) 

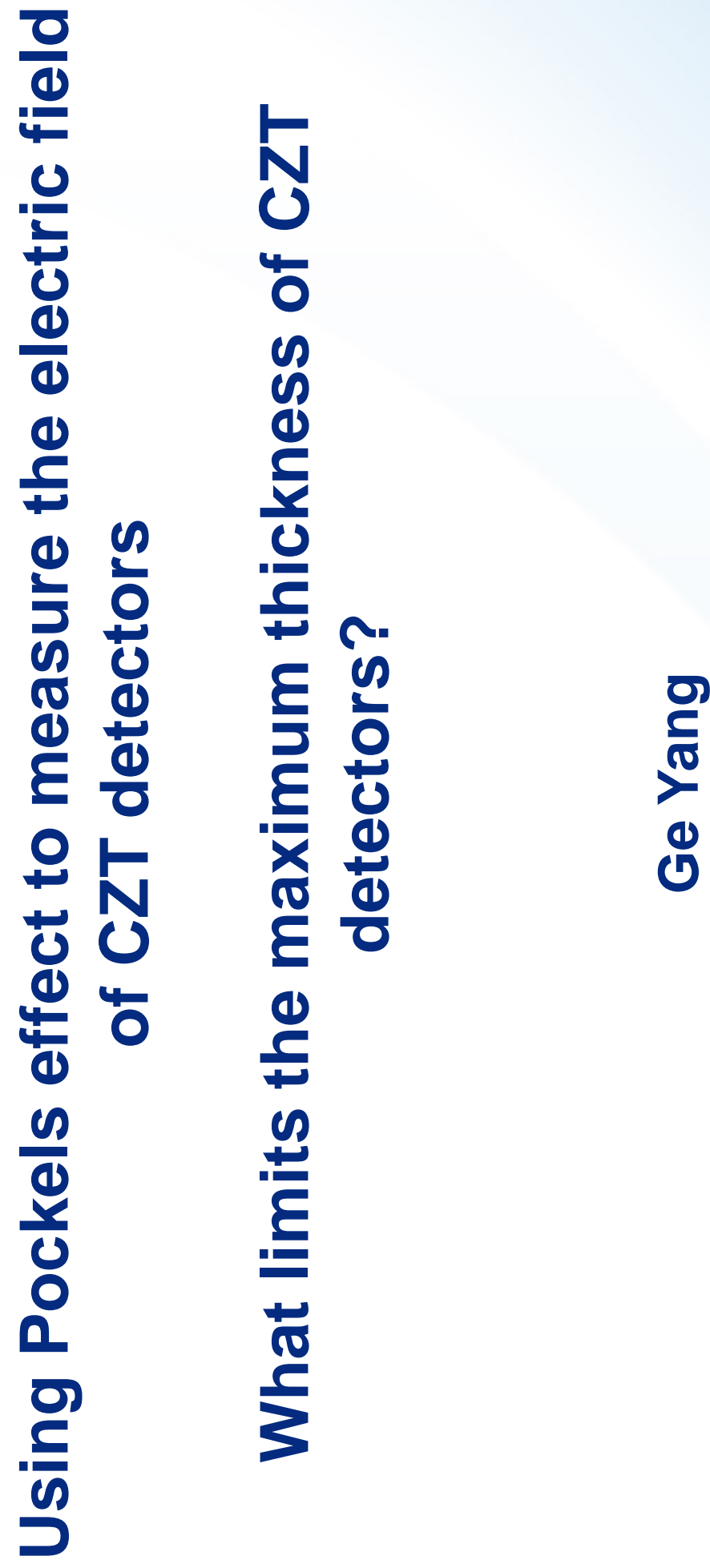

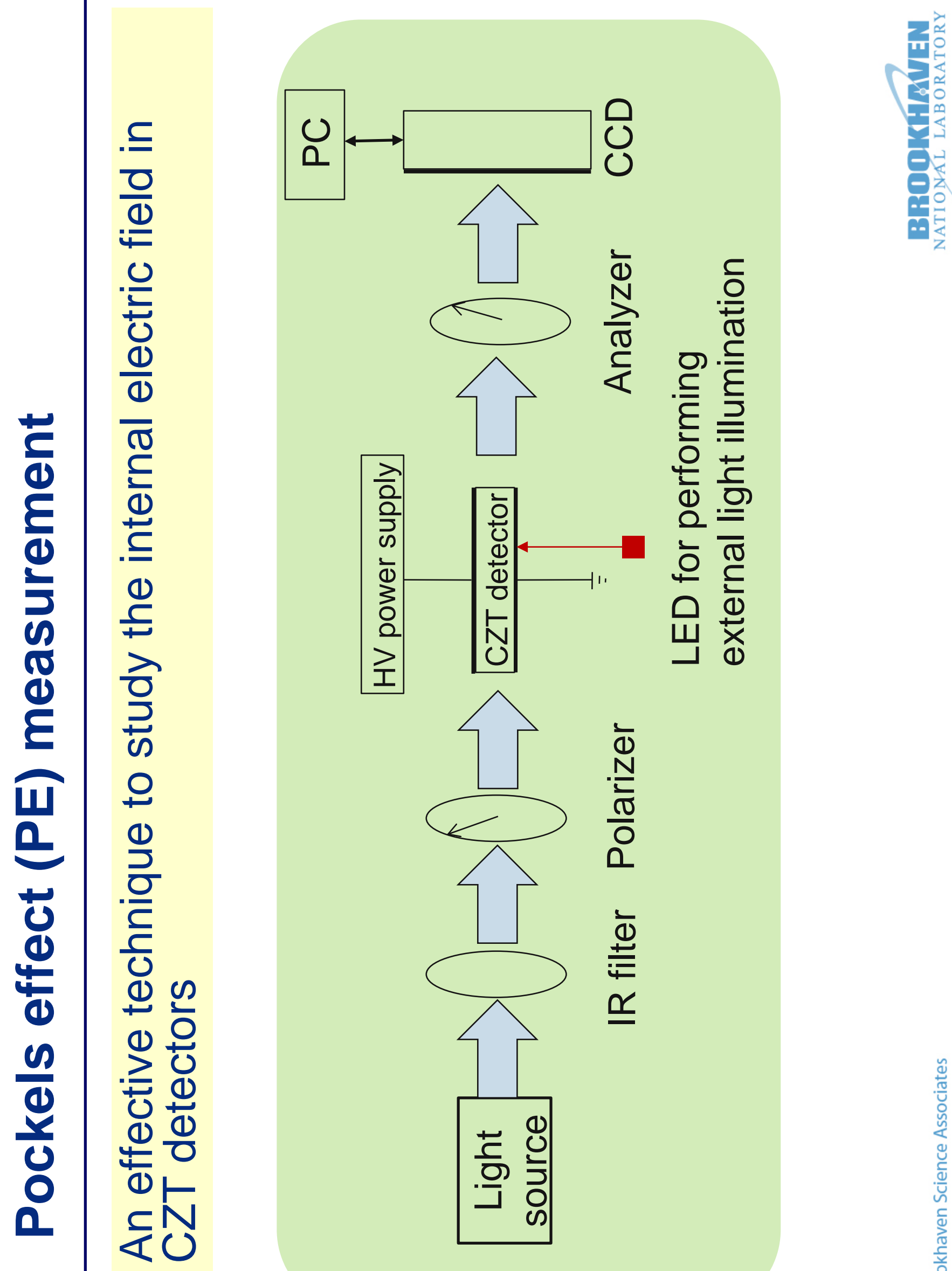


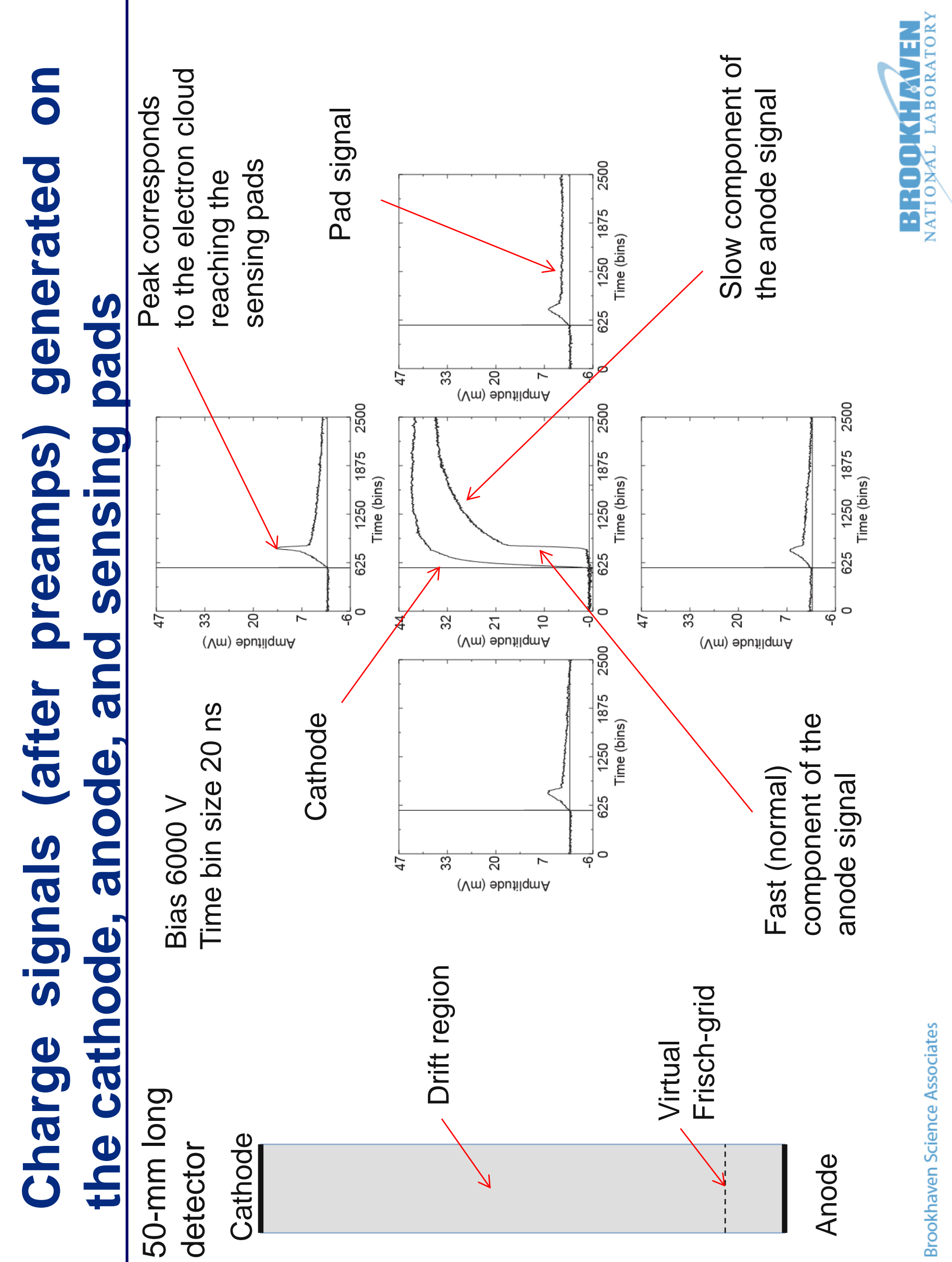




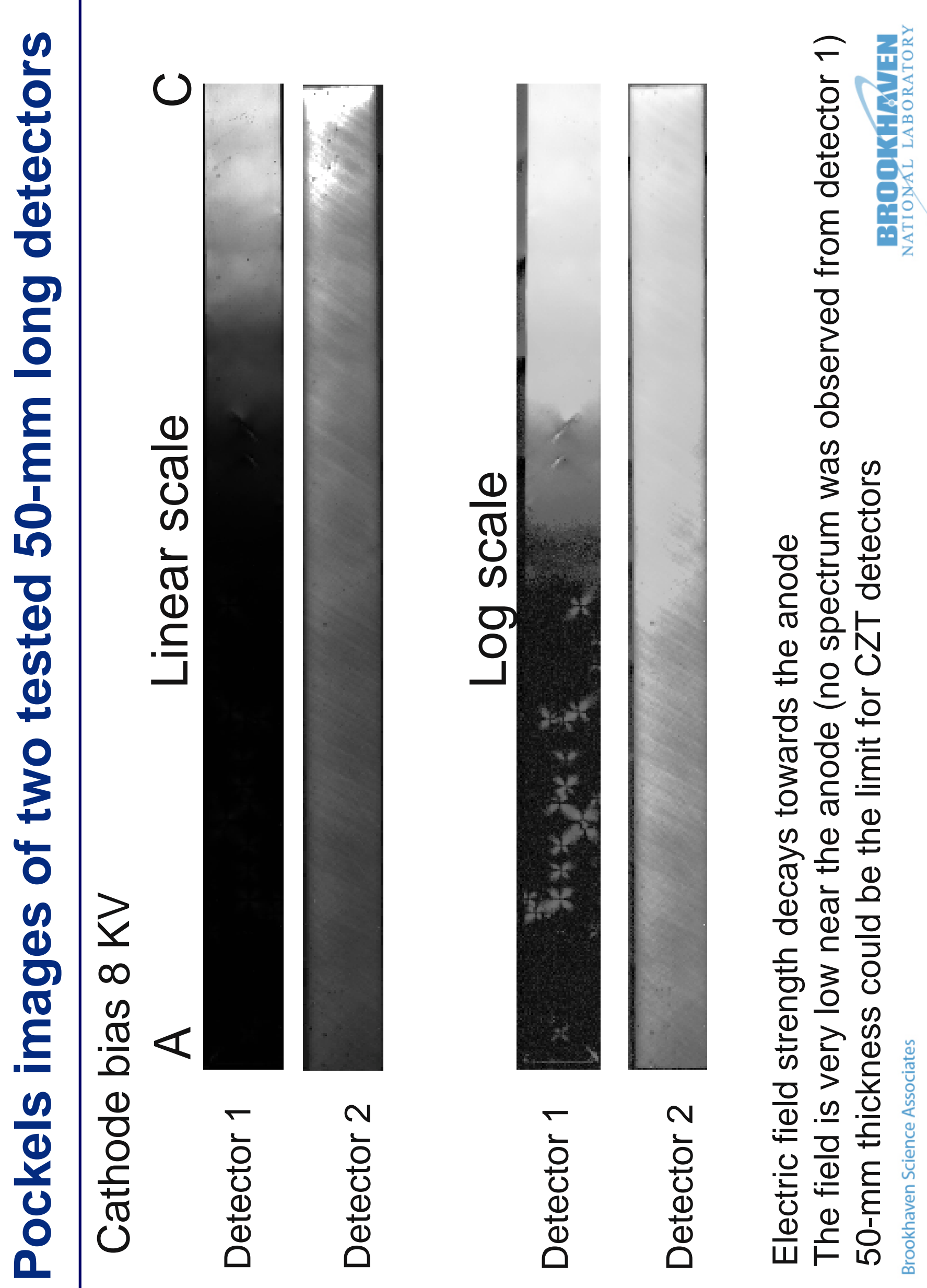



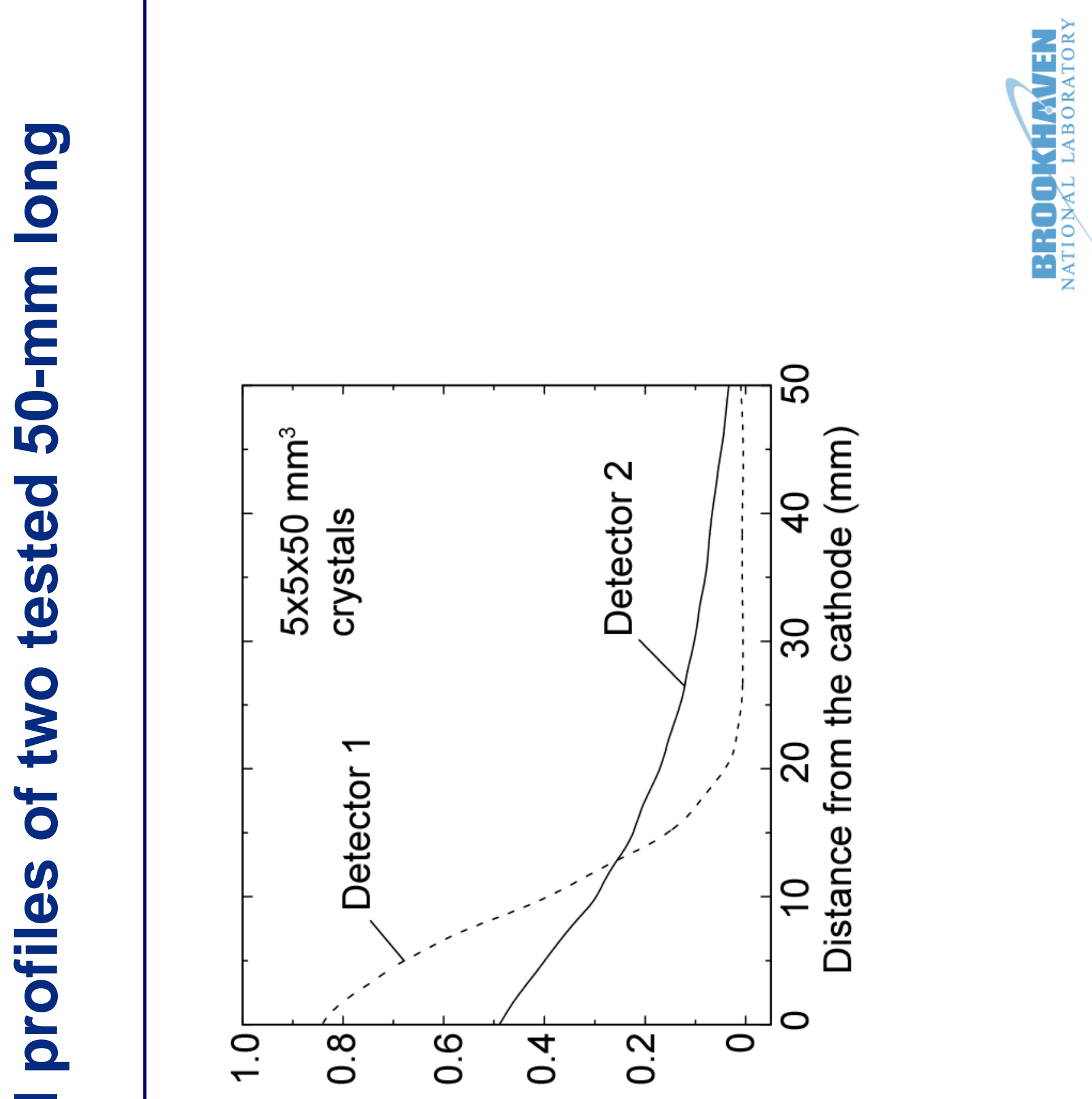

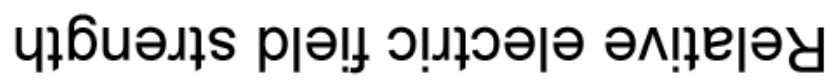




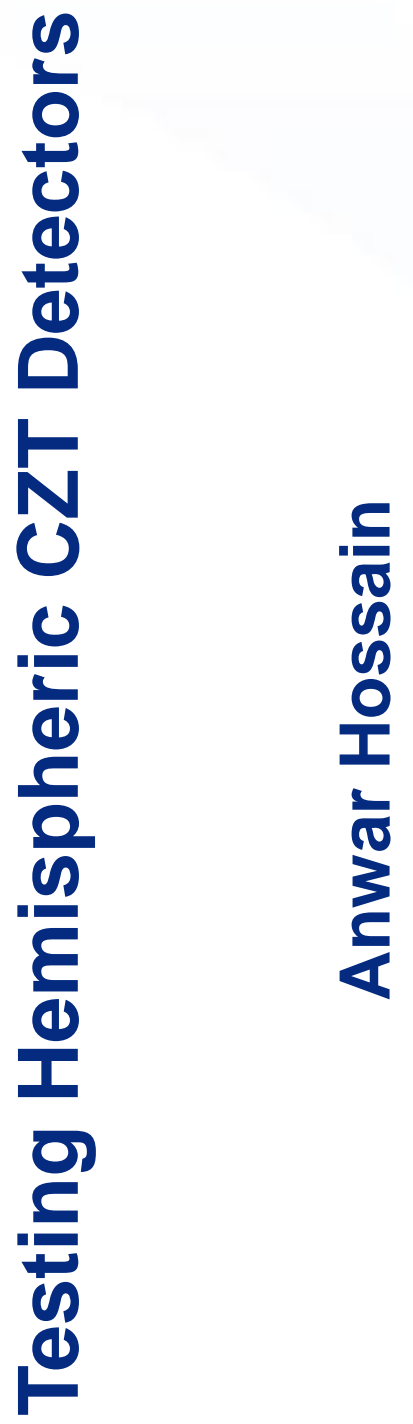


tே

음

ธี่

0

م

ro

한

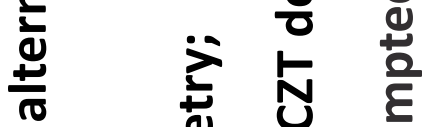

ט.

ह

일 보 을

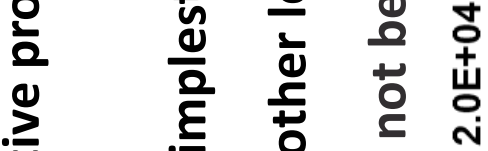

릴

\& $\quad$ \&

苟

일

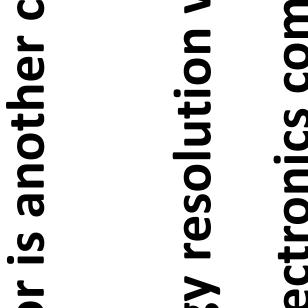

난

붕

(1)

(1)

$\frac{7}{0}$

$\overline{10}$

정

C

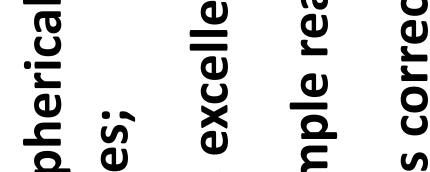

ํํำ

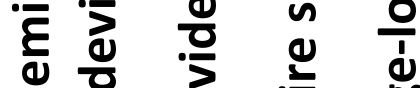

ฮ خ

을 을 훙

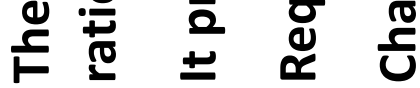

$\square$
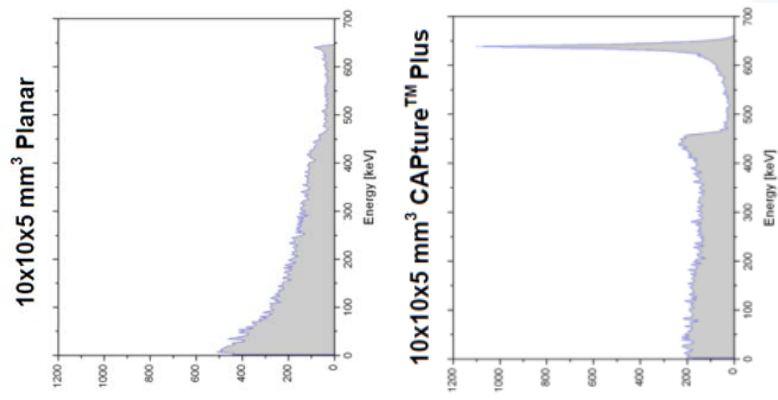

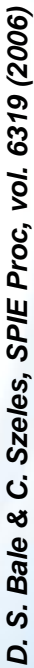




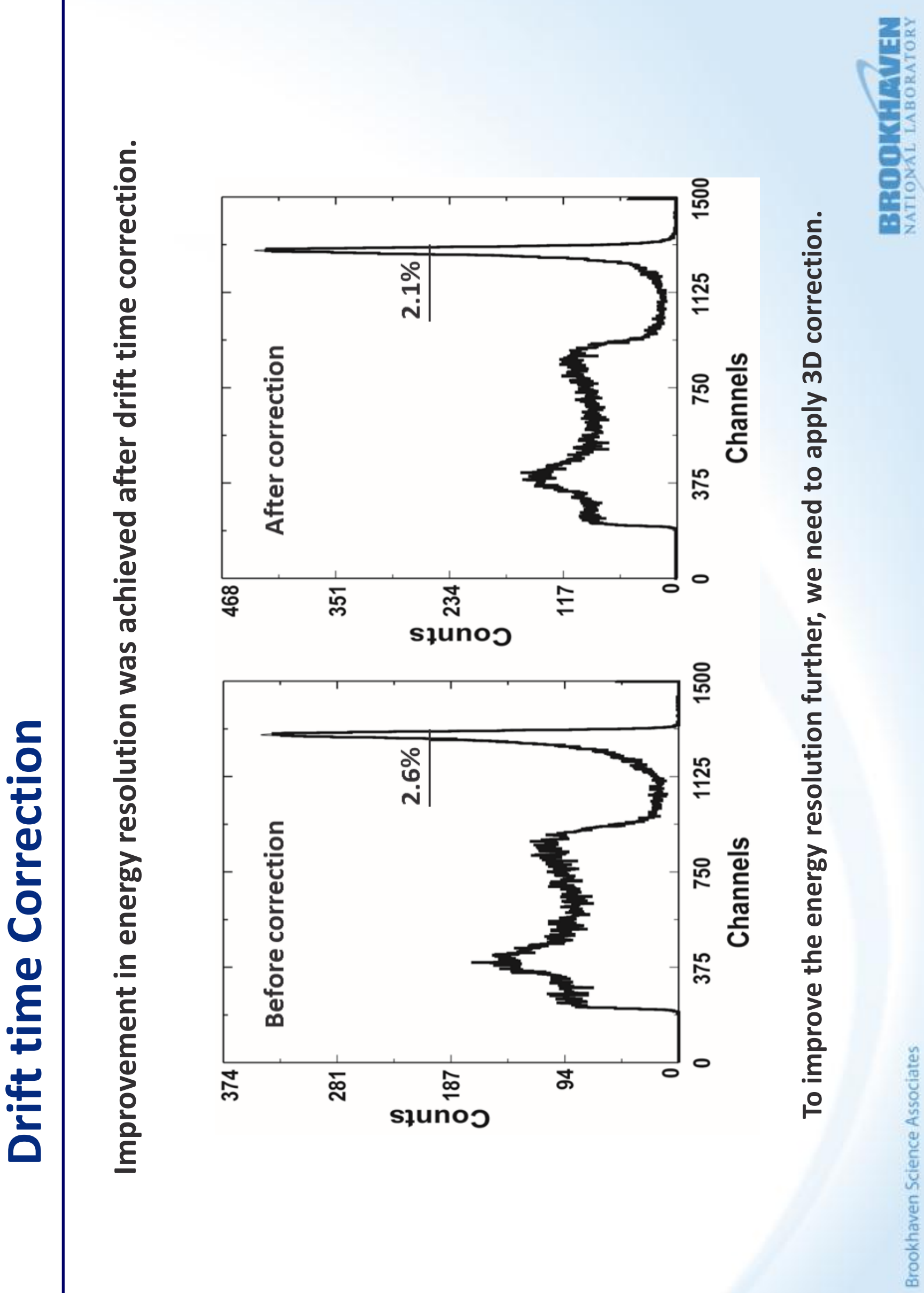




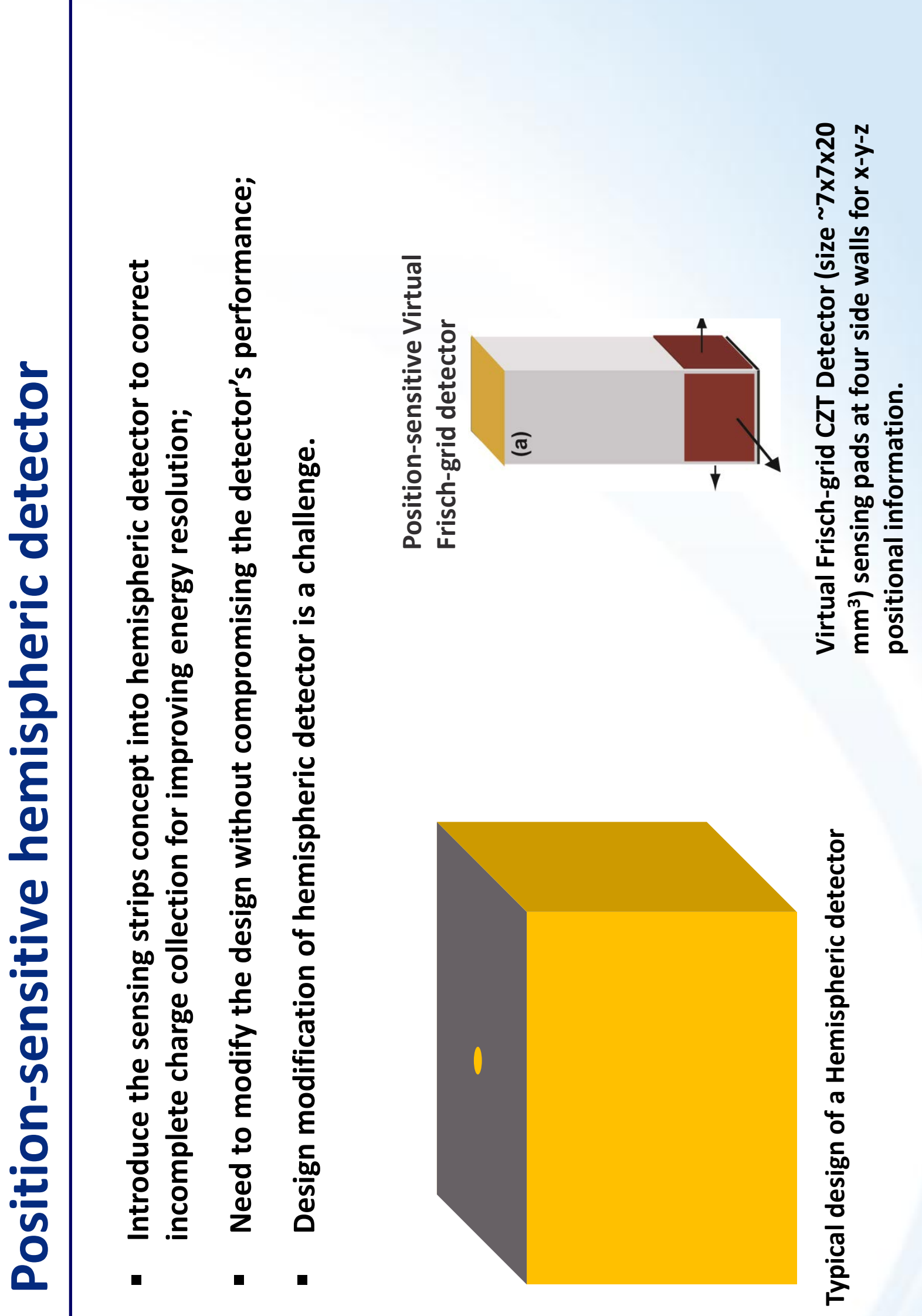



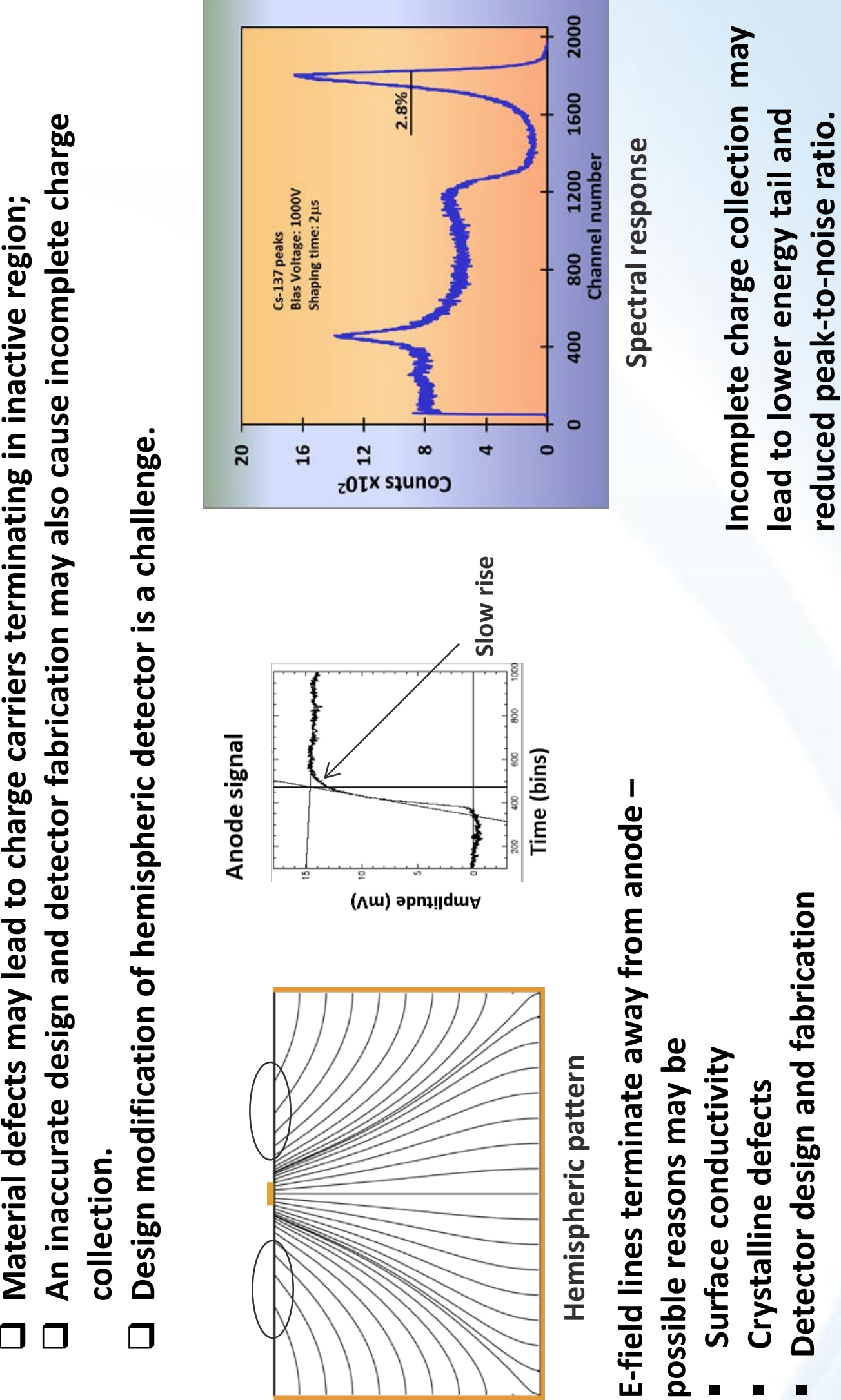


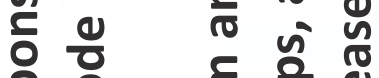

은 은 은 인

ญ 븐

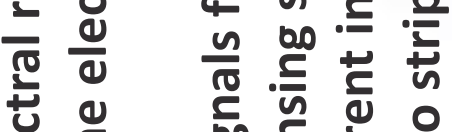

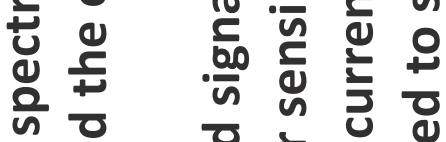

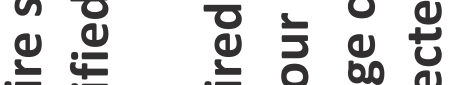

.气 专

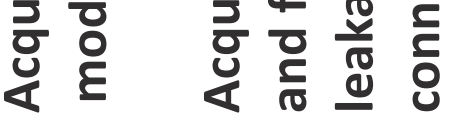

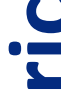

-

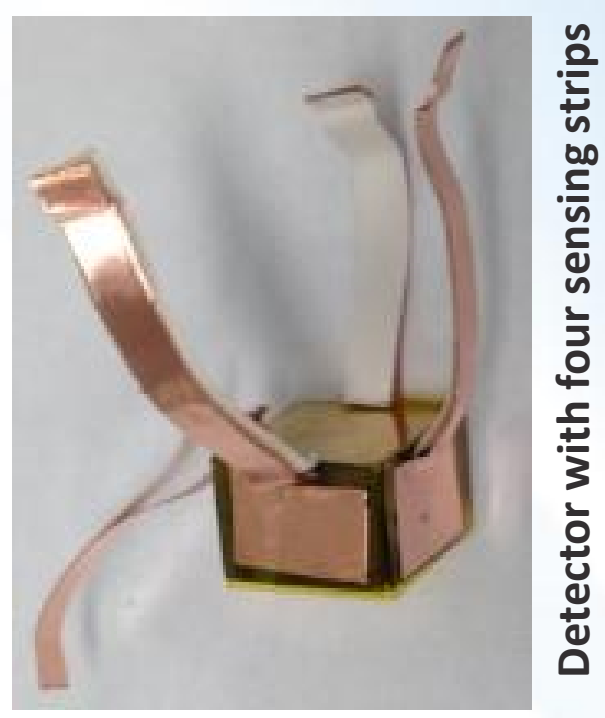

(1)

Q
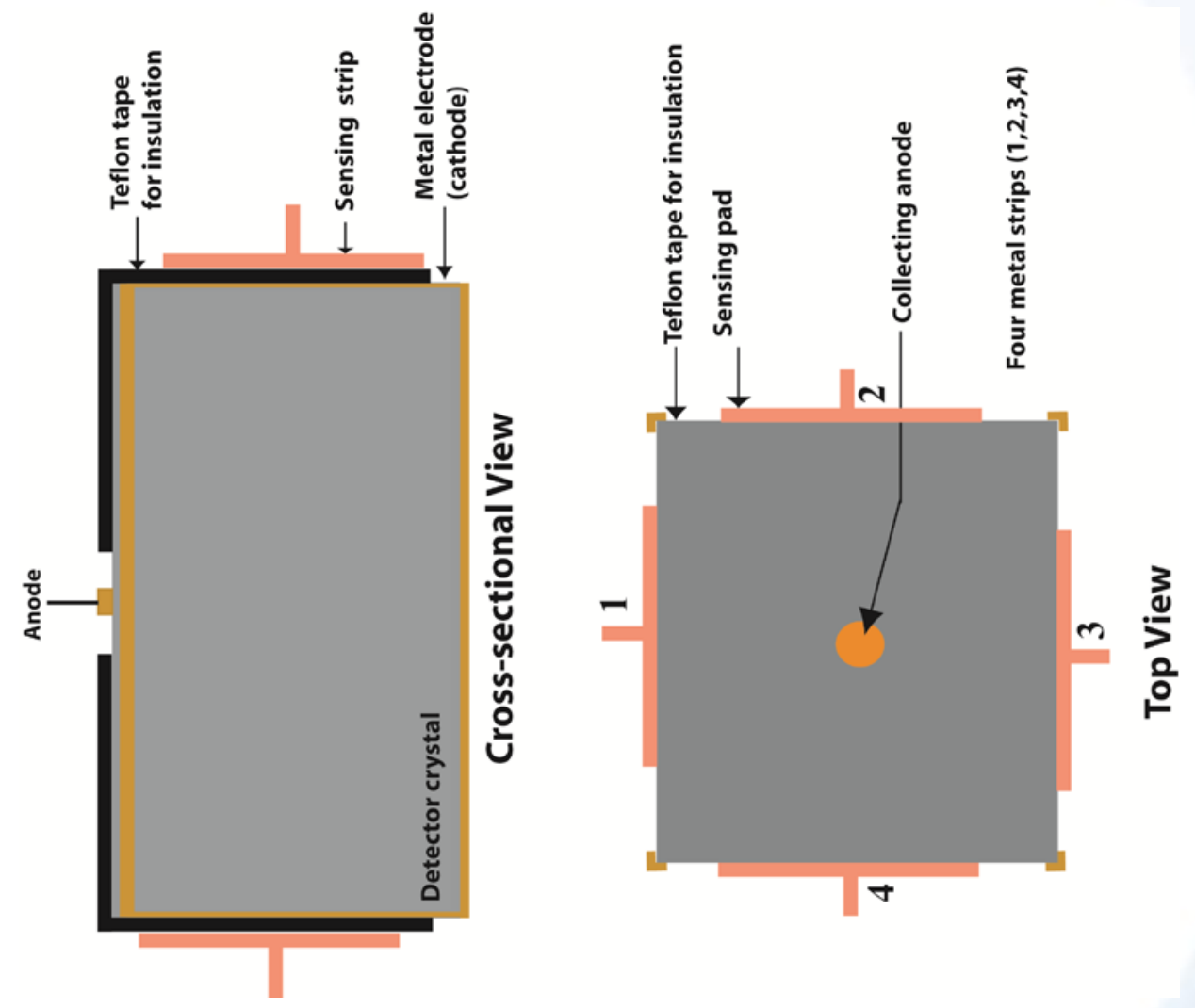


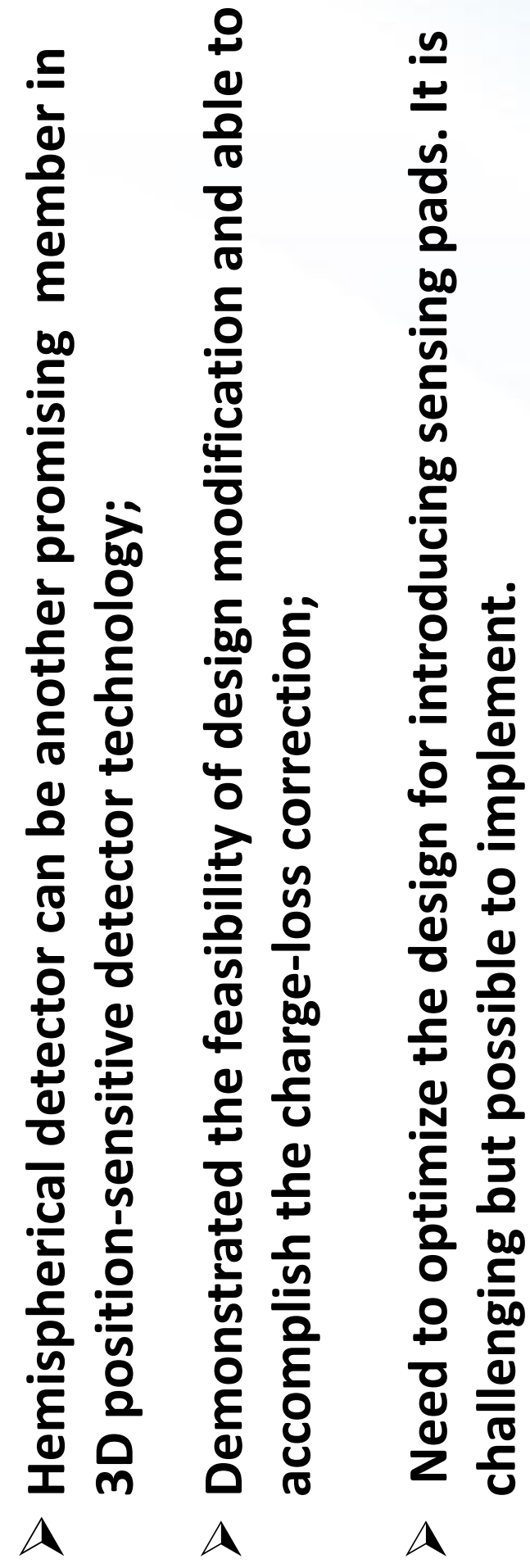




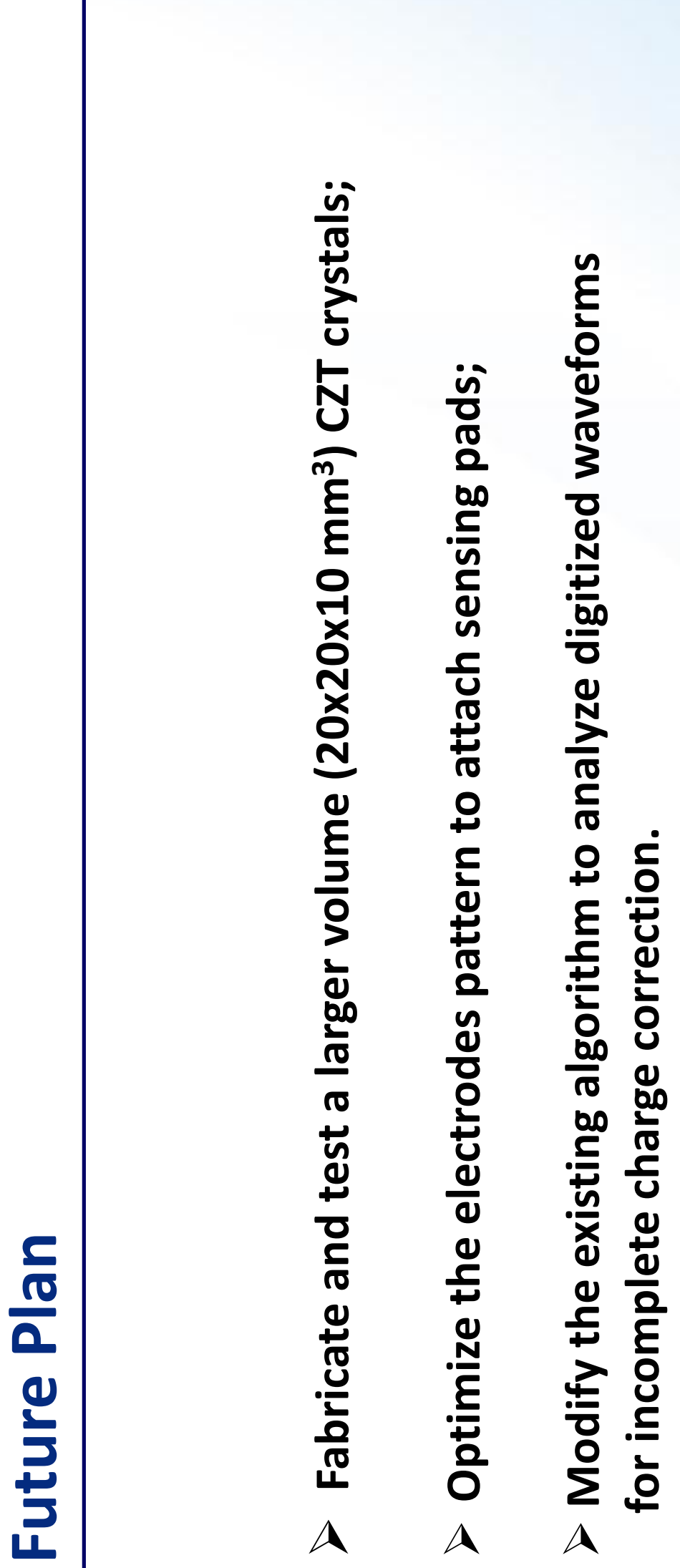


(1)

0

()

(1)

()

E

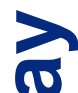

$\geqslant$

(O)

()

10

10

है

$\boldsymbol{H}$

0

(1)

0

0

อ 


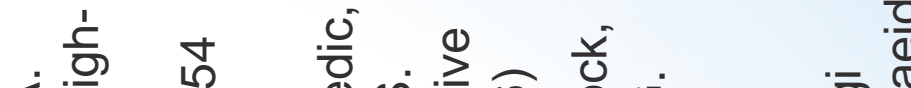

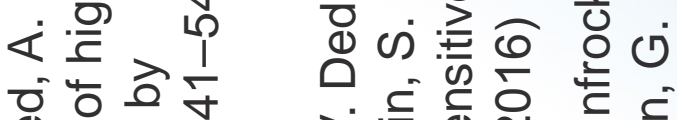

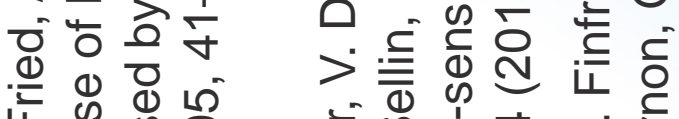

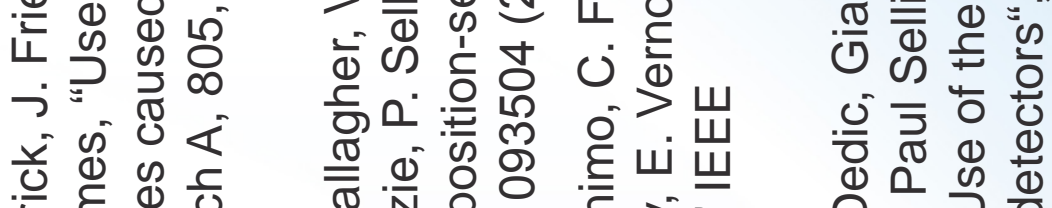

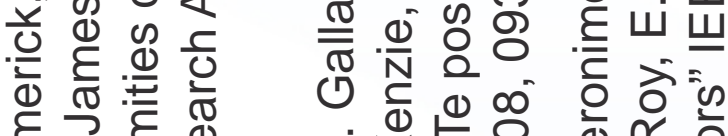

㟧

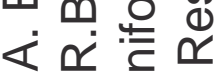

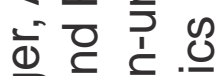

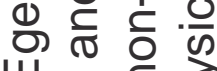

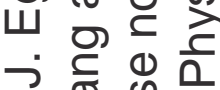

$0>$

हो

들

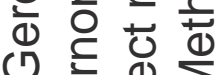

(1)

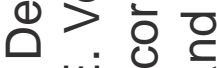

ن.

()

뚠

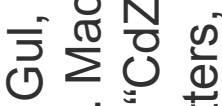

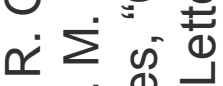

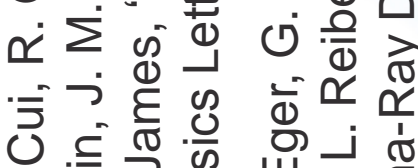

造造

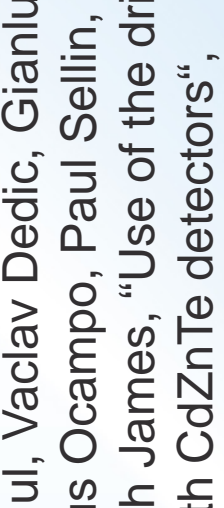

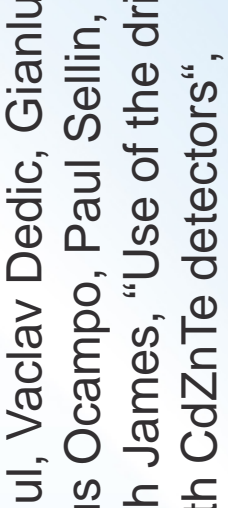

迹

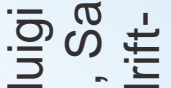

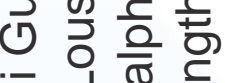

을

$\succ$.

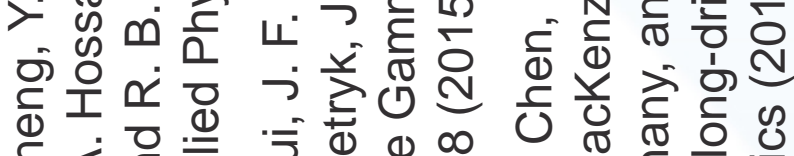

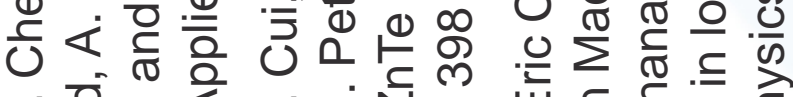
v.

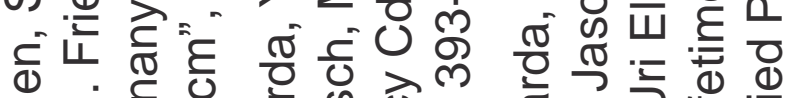

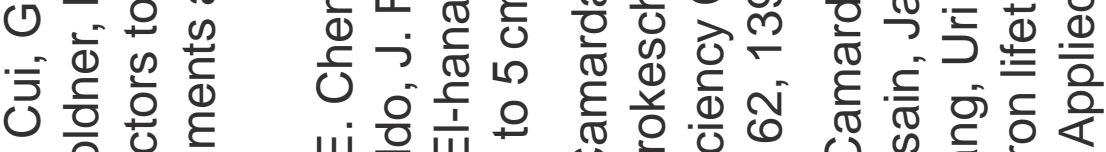
$\succ$ 잉

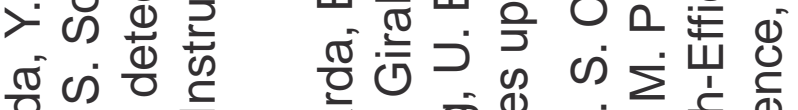

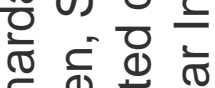

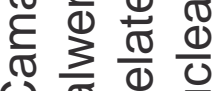

U.

نं 0 造 is के

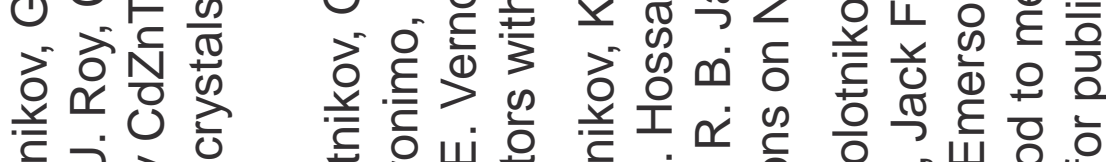

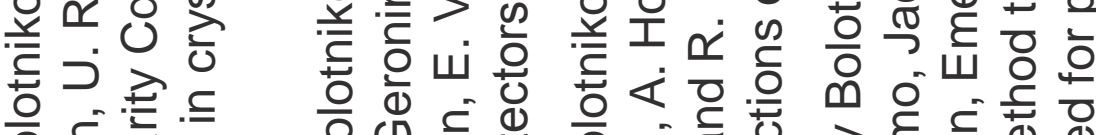
응.

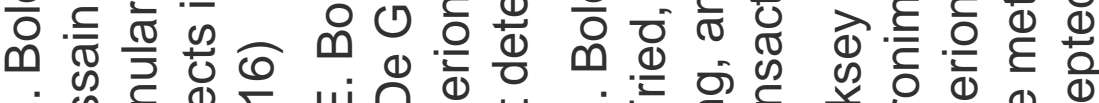
山

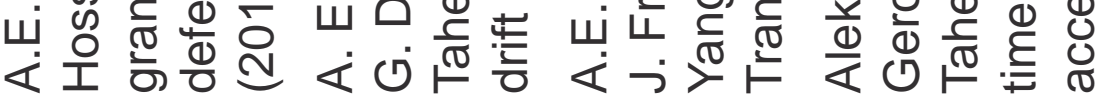
ठิ

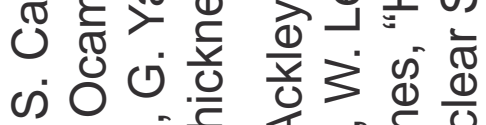

ज.

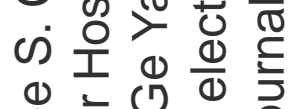

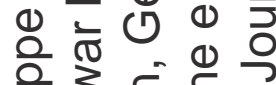

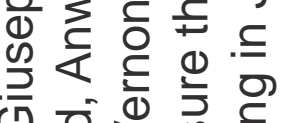

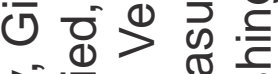
วั0 
$\subseteq$

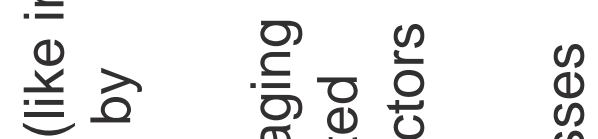

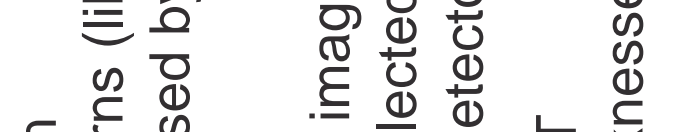

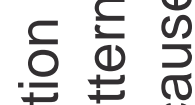

त

$\therefore \frac{0}{2}$ \&

ㅇ.

을

कृ б 흐

둥 을

웡

$\propto \geq$

ㄷํㅇ

U.

응 $\frac{2}{3}$

$\subseteq$ की

त̄ 흠

$\varepsilon$ 过

嵌

등ㅇㅇㅇ

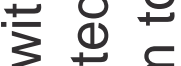

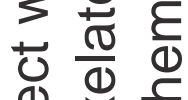

议

운응 응

굴 웡

출 흥 웜

के 9

청ㅁㅇ

흠 흥

$\frac{\pi}{2} \frac{n}{4}$

ॠ

\& 0 \&

흐응 응

匀

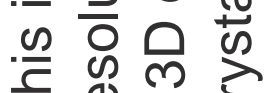

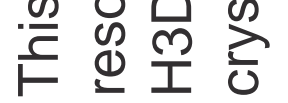

它号

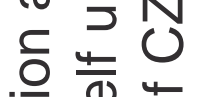

N勺

$\cong$

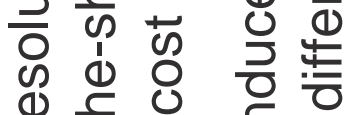

广

든

:을 일

을 든 흔

음 음

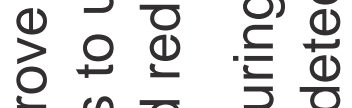

흔은응 응

छ

Э을 를

बं $\overline{\overline{3}} \frac{0}{0}$ 흠

б उ

등 ते

응 응

응

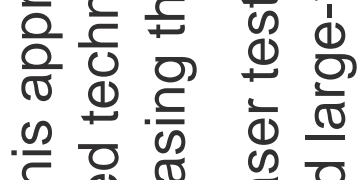

워

प人

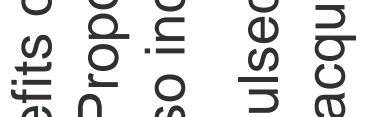

Q 0 is

$\bar{\Phi}$

$\subseteq \frac{\pi}{0}$

कृ

路卡

밍

$\sigma$ 용

후 $\frac{N}{\omega}$

능

응 흔

屯 항
웡

寻过 $\begin{array}{r}\frac{4}{0} \\ \frac{y}{0} \\ \hline\end{array}$

ह $\frac{.}{\sigma}$

ह

응

음

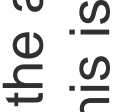

(1)

№

ह $\frac{1}{\bar{x}}$

응 즌

을 을

증

응 읃

ㅈ․ 으

$\stackrel{\frac{9}{\complement}}{\risingdotseq}$

의은

엉

过

응 응

(1) ত্

क

$\stackrel{0}{\frac{0}{\sigma}}$

응

高

ฮ્

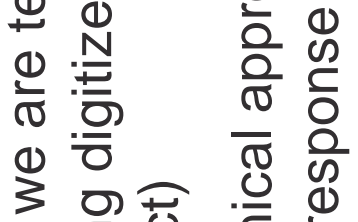

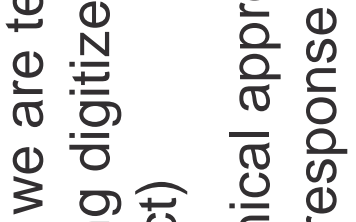

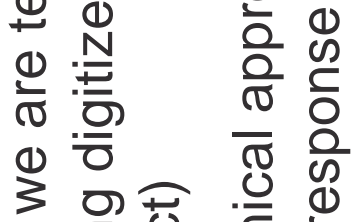

交产过

ब잉

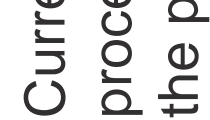

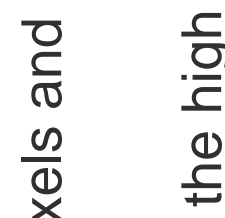

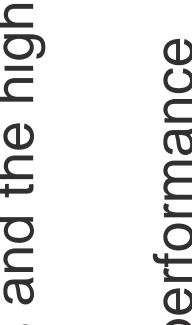

के

苛

อั้

드의

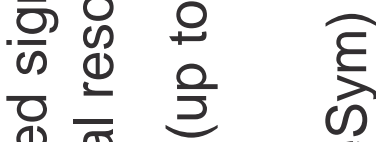

$\Phi$ क्ष के

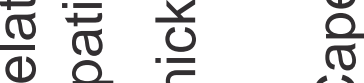

के

車

$\bar{d}$

$\stackrel{ \pm}{\frac{\pi}{5}}$

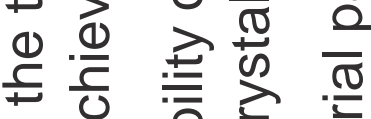

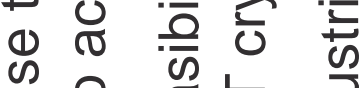

요요유

$\circ$ ฯ

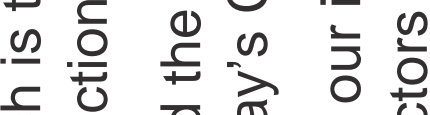

U 웡

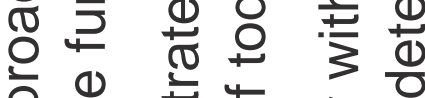

응 फ ๙

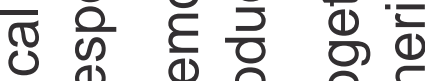
응 - $\frac{0}{2}$ 元 ○े 


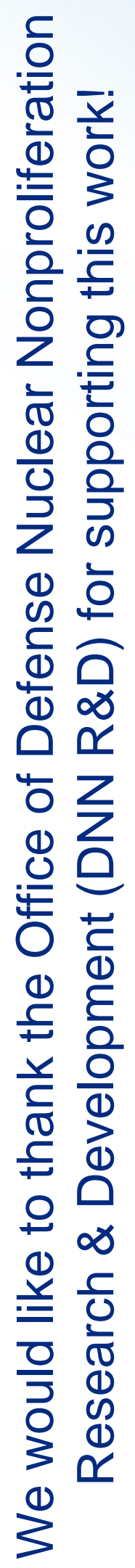

